\title{
Kernos
}

Revue internationale et pluridisciplinaire de religion grecque antique

$8 \mid 1995$

Varia

\section{Epigraphic Bulletin for Greek Religion}

\section{Angelos Chaniotis and Eftychia Stavrianopoulou}

\section{CpenEdition \\ Journals}

\section{Electronic version}

URL: http://journals.openedition.org/kernos/605

DOI: 10.4000/kernos.605

ISSN: 2034-7871

\section{Publisher}

Centre international d'étude de la religion grecque antique

\section{Printed version}

Date of publication: 1 January 1995

Number of pages: 205-266

ISSN: 0776-3824

Electronic reference

Angelos Chaniotis and Eftychia Stavrianopoulou, «Epigraphic Bulletin for Greek Religion », Kernos [Online], 8 | 1995, Online since 11 April 2011, connection on 16 September 2020. URL : http:// journals.openedition.org/kernos/605 
Kernos, 8 (1995), p. 205-266.

\section{Epigiraphic Bulletin for Greek Religion 1991 (EBGR)}

This fifth issue of $E B G R$ presents the publications of 1991 along with several addenda to $E B G R$ 1987-1990. The division of the work between New York and Heidelberg, for the first time this year, caused certain logistical problems, which can be seen in several gaps; some publications of 1991 could not be considered for this issue and will be included in the next $E B G R$, together with the publications of 1992 . We are optimistic that in the future we will be able to accelerate the presentation of epigraphic publications. The principles explained in Kernos, 4 (1991), p. 287-288 and Kernos, 7 (1994), p. 287 apply also to this issue. The abbreviations used are those of L'Année Pbilologique and the Supplementum Epigrapbicum Graecum. We remind our readers that the bulletin is not a general bibliography on Greek religion; works devoted exclusively to religious matters (marked here with an asterisk) are presented very briefly, even if they make extensive use of inscriptions. In exceptional cases (see $n^{\circ} 87$ ) we include in our bulletin studies on the Linear B tablets.

We would like to express our gratitude to various scholars for encouragement, helpful criticism, and the sending of offprints. We are aware of the fact that many publications escape our notice. Receiving offprints, especially of less accessible publications, would certainly help our work. We are very much obliged to Lisa Brody for improving the English text.

\section{Additional abbreviations}

Achaia und Elis:

Agora, XIX:

Aphrodisias Papers, 2:

Asia Minor Studien, 3:
A.D. RizAKIS (ed.), Achaia und Elis in der Antike. Akten des 1. Internationalen Symposiums. Atben, 19,-21. Mai 1989 , Athens, 1991.

The Athenian Agora. Volume XIX. Inscriptions, Princeton, 1991.

R.R.R. SMITH - K. ERIM (eds.), Aphrodisias Papers 2. The Theatre, A Sculptor's Workshop, Pbilosophers, and Coin Types, Ann Arbor, 1991.

Forschungsstelle Asia Minor im Seminar für Alte Geschichte der Westfälischen Wilhelms-Universität Münster, Studien zum antiken Kleinasien. Friedrich Karl Dörner zum 80. Geburtstag gewidmet (Asia Minor Studien, 3), Bonn, 1991. 
$A S T$, IX:

Atalay Memorial:

De Anatolia Antiqua

Eleutherna:

Ergon, 1990:

Hellenika Symmikta:

Hellenismos:

L'espace sacrificiel:

Magika Hiera:

Mélanges Bernand:

Orpbisme:

Praktika, 2:

Seleucid Kingdom:
IX Arastirma Sonuclari Toplantisi, Ankara, 1991 [1992].

H. MALAY (ed.), Erol Atalay Memorial, Izmir, 1991.

J. DES COURTILS - J.-C. MORETTI - F. PlaneT (eds.), De Anatolia Antiqua 1, Paris, 1991.

H. VAN EFFENTERRE - TH. KAlPAXIS - A.B. PETROPOUloU -

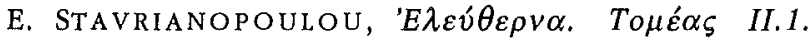

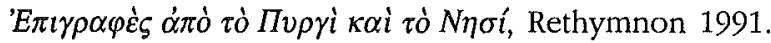

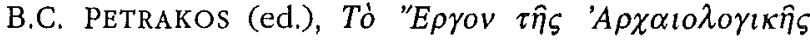

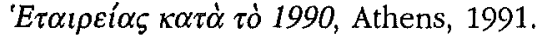

P. GOUKOWSKY - C. BRIXHE (eds.), Hellenika Symmikta: bistoire, archéologie, épigraphie, Nancy, 1991.

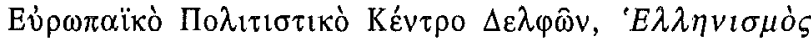

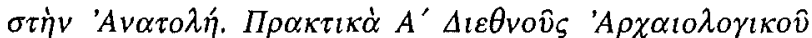

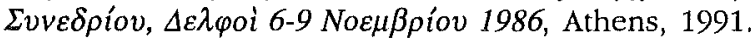

R. ÉTIENNE - M.-T. LE DINAHET (eds.), L'espace sacrificiel dans les civilisations méditerranéennes de l'antiquité. Actes du colloque tenu à la Maison de l'Orient, Lyon, 47 juin 1988, Paris, 1991.

C.A. FARAONE - D. OBBinK (eds.), Magika Hiera: Ancient Greek Magic and Religion, New York-Oxford, 1991.

N. FICK - J.-C. CARRIÈRE (eds.), Mélanges Étienne Bernand, Paris, 1991.

P. BORGEAUD, (ed.) Orphisme et Orphée, en l'bonneur de Jean Rudbardt (Recherches et Rencontres, 3), Genève, 1991.

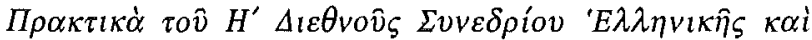

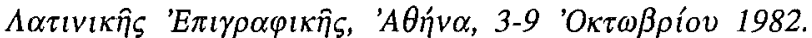
Tómo६ $B^{\prime}$, Athens, 1987 [1991].

P. BILDE - T. ENGBERG-PEDERSEN - J. ZAHLE (eds.), Religion and Religious Practice in the Seleucid Kingdom, Denmark, 1990.

\section{Selected topics $[\mathrm{AC}]$}

Geograpbical areas (in the sequence adopted by the SEG)

Attica: 2. 3. 30. 60. 65. 72. 84. 86. 93. 94. 97. 98. 119. 124. 138. 142. 154. 175. 180. 182. 183, 194. 209. 215. 236. 238. 239. 240, 244. 265. 270, 274. Aigina: 113. Peloponnesos: Korinthia 12. 194; Argolis 134. 139. 140. 141. 184. 194; Lakonia 39. 62. 85. 132. 227; Messenia 233. 234. 235; Arkadia 75. 136. 225; Elis 12. 75. 82. 136. 176. 220. 221. 222. 259; Achaia 137. 177. Megaris: 194. Boiotia: 10, 13. 74. 168. 224. Delphi: 27. 56. 58. 95, 135. 138. 144, 256. 257. Ionian islands: 229. Thessaly: 43. 76. 89, 105. 106. 153. 174, 248. 249. Epeiros: 5. 6. 8. 33. 35. 55. 136. 159. 266. Illyria: 34. 35. 58. Macedonia: 7. 43, 95, 123, 130, 194. 216, 217, 231. 237, 246. 267, 281. Thrace: $44.110 .131,172.260$. Moesia: 197,204 . North Shore of the Black Sea: 38. 96. 245. 263. 264. Delos: 30 45. 51. 111. 218. 242. 243. Dodecannes: 67. 103. 121. 122. 149. 171. 189, 194. 198. 199. Cyclades: 12. 73. 152. 156. 194. 255. Chios: 71. 
Lesbos: 1. 179. 194. 276. 277. Lemnos: 9. 29. Thasos: 12. 194. 204. Samothrake: 223. Euboia: 36. 126. 250. 275. Crete: 21, 41. 59, 64. 87, 120, 121, 173. 185. 226. 251. 252. 253. Sicily: $57,117,226$. Italy: $38.78,121.153 .164 .167$. Danubian Provinces: 24. Mberia: 22. Britannia: 77. 78. Asia Minor: 46. 109. 133. 204. 228, 230. 241; Karla 23. 28. 66. 101. 109. 201; Ionia 4. 31. 91, 116. 160. 186. 187. 190. 193. 195. 204. 205. 206. 273; Lydia 49. 76. 102. 124. 163. 181. 188. 204. 207. 253; Troas 191. 192. 204; Mysia 53. 200. 204; Bithynia 48. 50. 204; Pontos 109. 146. 166; Galatia 204; Phrygia 15. 47. 52. 202. 203. 204. 208; Pisidia 40. 107. 165; Pamphylia 64. 204. 211. 273; Lykia 28. 108. 211 278; Lykaonia 204; Kilikia 68. 70. 169. 212; Kommagene 210. 213. 214. 219. 271. Cyprus: 11, 170. Mesopotamia: 148.258 . Syria: 20. 83. 118. 127. 232. Palaestina: 196. Arabia: 81.128 .279 . Egypt: 16. 17. 18. 25, 32.61. 63. 99. 100, 104. 112. 151. 154. 269. North Africa: 68

adyton: 100,226

agon / agonothetes: 13. 18, 40. 42. 50. 67, 79. 81. 96. 126. 132, 162, 163. 182. 199. 212. 222. 224, 230. 233. 235. 238. 239. 240.250.256. 273. 274

altars: 31. 47. 70. 96. 98. 110. 111. 114. 120. 122. 139. 140. 141. 148. 184. 186. 200. 213. 271. 278

amphictionies: 27. 41. 144. 221

amulets: $78,118.127 .129,158,164$

angels: 118.164 .202 .254

animals: billy-goat 226 ; boar 253 ; bull 253 ; eel 217 ; fish 99; goat 97 . 194; lamb 235; ox 173. 226 ; pig 194. 218. 226; ram 226. 253; sheep 97. 226; also see sacrificial animals

anniversaries: 42

apotropaic inscriptions / symbols: $12.78,116.157 .160$

aretalogies: 133

associations: 16. 23, 28, 30, 47. 50, 54. 81, 100, 119. 133. 138, 198, 199. 202, 211, 219. 230. 264

astrology: 83

asylia: 193.273

banquet: 42.90 .226

birthday: 32.233

calendar: 144.222 .226

carrying of objects (in processions): 195.206

cave, sacred: 35.41 .211 .255

Christianity: $14.25,63.164$

chthonic cult: 184, 227. 259. 267; see also Greek words, epithets (chthonios)

'confession inscriptions': 12.76 .188 .254 .261

conversion: 133

crossroads: 115

crowns: see wreaths

cult images: 2. 150.160. 206

cult objects / parafernalia: hiera trapeza 214; see also altars, Greek words

curses: $12.57,69.91 .92,204.228,237,253,261,272.276 .278$; see also funerary imprecations

dance: 132 
death: $53.80,228$

dedications: $2.3,14.23,121,135.136,187,244.256 .257$; 'anatomical votivs' 2.72 .73 ; tithe 256.265 ; torches 245 ; vases 82 ; weapons 136.220 .256 ; after a victory 136. 256; official d. 82. 221. 256; replacement of d.94; melting down of d.94; dedicatory formulas 88, 113, 220, 24

defixiones: see curses

deification: 126 (L. Mummius). 162 (Antinoos). 217 (Alexander)

deities: Agathos Daimon 19. Aphrodite 19. 23. 28. 41. 49. 64. 66. 142. 158. 167. 175. 176. 194. 201. 231. 253. 269. 279; Basileia 199; Euschemon 231; Hegemone 183; Ourania 121. 244; Pythonika 267; Stratonikis 116. 186. Apollon 15. 23. 28. 60. 83. 102. 103. 106. 130. 142. 156. 160. 191. 207. 229. 232. 238. 245. 255. 256. 257; Bilkonios 253; Dauterenos 24; Deiradiotes 139; Delios 23. 28. 51. 156. 242; Delpbinios 12. 253; Didymaios 160. 203; Hekatombios 281; Kareios 15; Karneios 23. 253; Kedrieus 23. 28; Kitharodos 15; Klarios 160; Krateanos 53; Libotenos 50; Lykeios 88. 253; Maleatas 139. 140. 141. 184; Patroos 98. 138. 163; Pedageitnyos 23; Pythios 23. 28. 56. 149. 253. 256; Samnaios 23. 28; Sasthraios 253; Soter 50; Styrakites 253; Xanthos 138. Ares 41, 60. 68, 83. 158. 253. Artemis 7. 9. 15. 23. 31. 35. 49. 75. 83. 107. 133. 137. 142. 160. 167. 205. 226. 248. 255. 259; Agrotera 226. 253; Amarynthia 126; Brauronia 133. 175; Daidaleia (?) 222; Delphinia 205; Eileithyia 74; Daidaleia 222; Ephesia 4. 31. 160. 206. 273; Hegemone 139; Koloene 160; Kyparissia 233; Limnatis 222; Mounichia 175; Orthia 132; Paphrakia 75; Perasia 70; Pergaia 23. 28; Pbosphoros 175. 189. 238; Pythia 205. 267; Soteira Bakchia 23. 28. Asklepios 2. 3. 15, 21, 23. 28, 31. 33, 63. 72. 73, 84. 95. 105, 121, 184, 198, 235. 236. 238, 249. 251; Soter 166. Athena 19. 83, 94. 136. 142, 211. 235. 247; Agoraia 253; Daidaleia (?) 222; Hygieia 209; Itonia 138; Kamiros 23; Kourotrophos 262; Lindia 149; Phratrios 98; Polias 23. 28. 70. 138. 149; Skiras 270; Skyllia 253; Sosipolis 256; Soteira 182. Britomartis 253. Charites 248. Demeter 19. 23. 75. 138. 142. 167. 180. 182. 245. 275. 276. 277; Azesia 138; Chamyne 259; Chthonia 227; Konia 259; Kourotrophos 70. 262; Megalartos 226. Demos 15. 23. 48, 66. 71, 201, Diktynna 253. Dione 64. Dionysos 19. 23. 28, 35. 46, 47, 87, 89. 124, 133, 142, 149, 163. 175, 196, 222. 227, 238, 264; Kallikarpos 70; Narthakophoros 23. Dioskouroi 23. 28. 61. 64. 78, 108. 138. 142. 245. Eileithyia 23, 28, 73. 74, 216. 234. 253; Kourotrophos 262. Ennodia 43. Enyalios 23. Eos 64. Eros 162. Etephila 179. Eueteria 23. 28, Eukleia 7. Ge 153. 235; Kourotrophos 138, 262. Hekate 23. 28. 115. 175. Helena 61. Helios 23. 60, 83. 149, 202. 235. 253. Hemithea 23. 28. Hephaistos 142. Hera 11. 28, 44. 64, 142. 167. 269. Herakles 23. 37. 44. 71. 83. 98. 108. 138. 157. 186. 199. 230. 245. 253. 270; Hoplopbylax 116; Propbylax 116; Soter 159 Hermes 19. 21. 23, 50, 68. 71. 112. 115. 142, 155. 162. 183, 194. 215. 230. 253; Cbtbonios 76. 248. 249; Kedrites 41; Kornisaios 41; Kourotrophos 262; Propylaios 23. Hestia 19. Horai 60. Hosios kai Dikaios 50. 202. 204. Hygieia 23. 31. 63. 236. Kabeiroi 44. 168. Kore 23. 182. 195. Kouretes 58. Kybele 7. 22, 49. 50, 52. 54. 85. 180, 208. 211. 277. Leukothea 245. Leto 15. 23. 28, 53. 253. Mes 254. Meter 49. 74, 138. 180. 208; Oreia 211; Meter Pbileis 76; Meter Theon 7. 85. Meteres 226. Mnemosyne 153. Moirai Patroiai 105. 
Muses 23. 141. 163. 208. 268. Nemesis 22. 50. 182. 183; Epekoos 201. Nereids 113. Nymphs: 21. 35. 73. 138. 142. 175. 226. Ouranos 153. Pan 19. 35. Patris 201. Peitho 194. 231. Persephone 89. 164. Plouton 142. Poseidon 30. 41. 142. 199. 247. 249. 253; Aigaios Asphaleios 200; Hippios 149. Pylon Epekoos 166. Synteleia 7. Roma 30. 163. 179. Themis 123, 183. Theoi Epekooi 48; Megaloi 86; Olympioi 70. Thea Hypsiste 181. Theos Agathos 19. 249; Hypsistos 23. 166. 170.181. 241. Tritopatreis 138. Tyche 212; Agathe Tyche 19. 32. 208. Zeus 28. 44. 50. 87. 101. 138. 203. 226. 235. 249. 252. 278; Agoraios 253; Ampelites 203; Astrapates 28; Atabyrios 23. 28; Diktaios 41. 253; Dimeranos 263; Dodonaios 6. 8. 266; Dolichenos 213. 219; Eleutherios 132. 138; Epikarpios 232; Helios 23. 52; Hypsistos 172. 279; Idaios 41. 253; Ithomatas 234. 235; Kataibates 23. 28, 122; Kretagenes 253; Ktesios 217; Kyrios 232; Labranios 170; Machaneus 226; Megistos 232; Meilichios 117. 217. 236; Messapeus 39; Olympios 50. 82. 107. 108, 136. 138. 148. 220. 221; Panamaros 23; Philios 217; Polieus 23. 28; Poliouchos 226; Pylaios 166; Sarapis 78; Skyllios 253; Solymeus 40. 107; Soter 19. 70. 182. 199. 212. 213; Tallaios 253; Thallos 52; Thenatas 253; Xenios 98

deities, Egyptian: 17. 22. 23. 25. 50. 61. 63. 70. 74. 78. 99. 112. 121. 130. 133. 227. 231. 232. 269; Oriental: 20 (Atargatis). 22. 23. 28. 49 (Anahita). 50 (Tataula). 54.83. 109. 148. 162. 232. 245. 258. 271

deities, female: 133; healing: see healing; rider: 110. 197; river 21. 233 (Acheloos). 25 (Nile) 138 (Kephissos); snake: 50. 217; water: 121; weather: 219; protectors of agriculture $24,70,203.227$; birth 175; children 162; cities: $23.28,70,138,149$; civic life 138; fertility 70. 162. 175; gates 23. 162. 166. 245; livestock 59. 183. 202. 203; magistrates 194; women 137; youth 175. 262; see also Greek words, epithets

deities, interpretatio Graeca of non-Greek deities: 20. 49. 50, 61. 63. 83. 148. 232. 269. 279

divination: 45.65 .151 ; see also oracles

dreams: 231

ephebes: see youth

Epimenides: 65

festivals: 23. 28, 30, 32, 42. 93. 97. 98. 107. 133. 134, 163. 182. 190. 206, 207, 209. 222. 235. 239. 240. 270.273

foundations: 206,207

funerary cult: 53. 68. 280; altars 47; banquets 53; imprecations 18. 34. 40. 53. 107. 133. 186. 204. 228; see also graves

ghosts: 68.115

Gnostics: 164

graves: grave altars 47; monuments 5. 53. 227; boundary stones of $g .: 138$; violation of $g .: 18.40 .53 .107 .174 .228 .247$; see also funerary cult

healing / healing miracles: 14, 31. 63. 72, 73. 129. 254; healing deities: 63. 110. 121. 162; see also deities, Asklepios

heroes, heroic cult: 10 (Amphiaraos), 23 (Abraikos). 60. 270 (Aglauros). 96 (Achilleus). 98 (Therrikles). 107 (Solymeus), 109 (Pankrates). 142 (Archegetes). 175 (Mounichos), 183 (Archegetes of Rhamnous), 197 (Irsaios), 
234 (Hegemone, Tripas). 270 (Eurysakes, Pandrosos); cf. 50. 96. 109. 142. 162. 184. 226; heroization 42. 211. 227; see also deities, Herakles

hierodoulia: 62

hieros gamos: 11

holocaust: 90.184

honey: 87

hymns: 42.145

imperial cult: $6,15,23,32,50,66,67,70,102,107,108,124,132,146,163,165,179$. 201. 207. 211. 225. 233. 235. 249. 273; identification of emperors with gods: 5 (Hadrian-Zeus Dodonaios). 107 (Hadrian-Zeus Olympios), 124 (Hadrian-Neos Dionysos?). 132 (Antoninus Pius-Zeus Eleutherios)

incantation: 129

incubation: 21.184

Initiation: 12.54. 88. 153; see also mysteries

inventories: see sanctuaries

invocations: $19,78,90,118,127,151,235,245.253 .273$

ithyphallic representations: 12.39

Judaism: 133.181 .241

justice: 69.128 .254 .261 .272

ktistes: 1. 186. 211

leges sacrae: 12. 23. 28, 133. 145. 147. 184. 194. 209. 210. 226. 252, 270. 271

magic: $44.68,69.78,90,115,127,128,129,151,160,164$; see also amulets, curses

manumission: 62.74

marriage: 244

miracles: see healing $\mathrm{m}$.

months: see calendar

moon, new: 115; moon-deities 148,162

Mycenaean religion: 87

mysteries / mystai: 47. 50. 54, 89, 142. 153. 162, 177. 211, 223. 230. 238. 263

mythology: 168. 268, 278

names, theophoric: 8 . 70; related to res sacrae: 74 (Theoterpidas). 248 (Pannychis). 263 (Mystes); names of deities given to mines: 142.215

neokoria: 273

Neoplatonism: 168

night rituals: 115.140 .184 .205 .238

oath: 18. 36. 68.92.160,185.235. 253

oracles: $14.21,23.27,31.55 .58,65.68,121.160 .162 .169,205.227 .266$

Orphism: 38. 89. 129, 153. 168, 177. 227. 264

Parthian religion: 19

periodonikes: see agon

personifications: 19; see also deities

philosophy and religion: see Gnostics, Neoplatonism, Pythagorism

phratry: 97. 98. 138

phylacteries: see amulets

pilgrimage: 14.154

politics and religion: 7. 41. 42.65.67.92, 109. 135. 193. 194. 206. 207, 264. 278 
pollution: 12.80 .115

prayer: 42.69 .90 .92 .129 .235 .245 .261 .272

priests: 2. 23. 92 . 104. 109. 145. 149. 211. 270; cursus honorum: 149; election: 211; eponymous: 33.48 .95 .149 . 234. 235; families of p.: 102. 179; hereditary 179; for lifetime: 163.179. 201. 225. 231; lists of p.: 23. 28; perquisites 97. 147; royal administration and p.: 104. 109. Other cult officials; agonothetes see agon; archimystes 211; architbiasites 211; archistolistes 100; bakchos 47. 230; dadouchos 235; diakonos 213; epoptes 223; hierokeryx 278; bieromnemon 27. 28. 48. 144. 246; bierophantes 47; bieropoios 28 . 183. 218; hierorgos 21 ; bierothytes 23. 28. 134. 149. 235; kistiokosmos 233; kosmophoros 14; mantis 235; nebeusasa 249; neopoios 103; neokoros 18. 21 ; odelonomos 134; paianistes 2; panegyriarches 50. 163; prostates 16. 233; pyrpboros 140; theagos 99; theokolos 176; theomantis 45; theothytes 256

processions: 42. 138 (Pythais). 206. 209; see also carrying of objects in pr.

purification: 68. 115

Pythagorism: 38.89

rebirth: 38.89 .264

revival of cults: 4

rituals: arkteia 175; biera nyx 140; koureion 97; meion 97; pannychis 238; see also hieros gamos

royal cult (Hellenistic): 26. 29. 182. 190. 191. 192. 193. 210. 211. 213. 214. 219. 260. 271

sacrifice: 23. 28, 42. 60. 87. 88. 92.97. 111, 145. 147. 183. 184. 190. 191, 194. 209. 218. 226. 235. 238. 253. 270; sacrificial animals 97, 111, 147. 194. 209. 218. 226. 253; skins of sacrificed animals 134. 147; sacrificial calendars 226; see also holocaust

sacrilege: 12,142

sanctuaries: 8, 10, 21. 23. 28, 41. 56. 75, 101, 109. 111, 121, 138, 149, 175. 187, 220. 221. 226. 254. 275; accomodation of suppliants 28 ; administration of 233. 242. 243; boundary stones 132. 138. 145. 180. 186. 213; finances 4. 8. 21. 24 . 51.94. 109. 111. 134. 242. 243. 270; inventortes of 2. 3. 28. 75. 94. 175. 238. 242; land of 4. 24. 28. 41. 51. 85. 109. 138, 186. 270; order in 28; probibitions in 12. 23; treasures 94. 121. 244

sexual intercourse: 12; vocabulary 12; sexuality 194

sin: 254

society and religion: 54.69.145. 149

soul: 153.264

stephanephoria: see wreaths

suicide: 80

superstition: 115

supplication: 28

symbols / symbolism: 168.228

syncretism: 20. 232. 241; see also deities, interpretatio Graeca

temples: 2. 23. 28. 50. 56. 83. 98. 145, 208. 209. 211. 227. 254. 279; temple-states: 109

theoria, theoros: 67. 93; theorodokos: 95

thesauros: 121. 244. 249

torches, torch-races: 53. 182. 274 
'voodoo dolls': 68. 69.237

vow: $14,24,31,72,77.78,108,188,248,249,254$

wax figures: $68,69,115,160$

weaving: 168

wine: 97.221

women: 133. 137. 179. 227. 241, 244. 269

wreaths: $42.51,115.182 .224$

writing / written word in religion: 14; retrograde w, (in magic) 69

youth: 42.164 .175 .185 .206

\section{Greek words}

associations: $\delta \varepsilon \kappa \alpha \delta 1 \sigma \tau \alpha i ́$ 50; $\sigma \pi \varepsilon \hat{\imath} \rho \alpha 47$

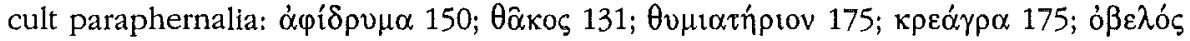

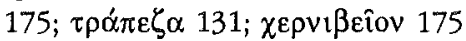

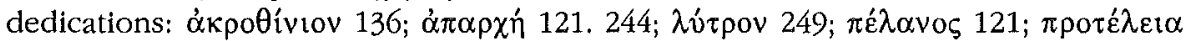
$\gamma \dot{\alpha} \mu \mathrm{ov} 244$

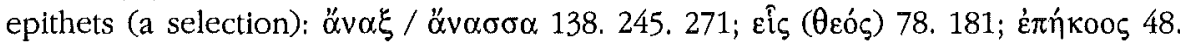

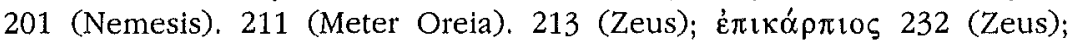

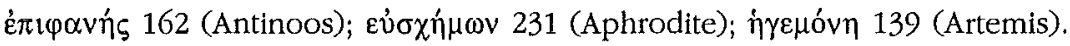
83. 183 (Aphrodite). 234 (Messenian heroine); кovpotpópos 138 (Ge). 262 (Athena, Ge, Demeter, Eileithyia, Hermes). 270; кúpı́ 232 (Zeus); $\mu \dot{\gamma} \gamma \alpha \varsigma$ et

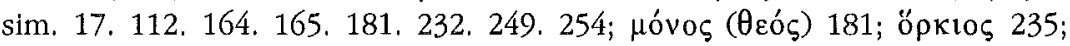

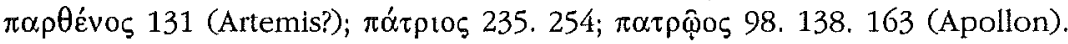

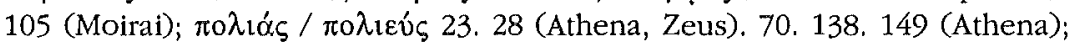

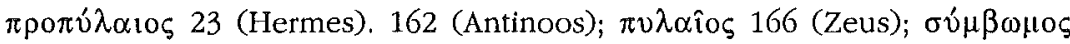

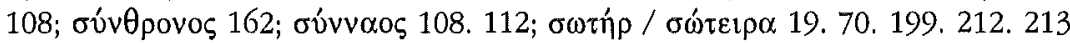
(Zeus). 23. 28 (Artemis). 50 (Apollon), 182 (Athena). 159 (Herakles). 166 (Asklepios). 249 (Augustus). 260 (Philip V); cf, 152; $\tau £ \chi v o \delta \hat{\imath \imath \iota \varsigma ~} 211$ (Athena);

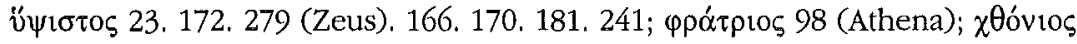
76. 248. 249 (Hermes)

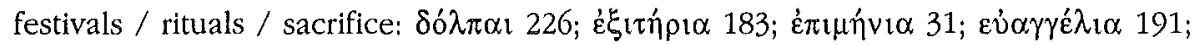

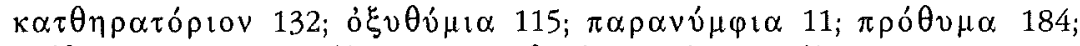

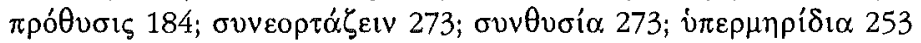

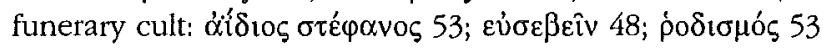

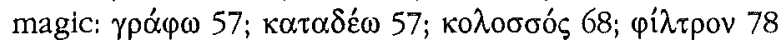

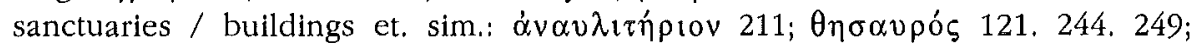

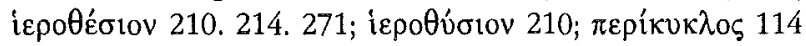

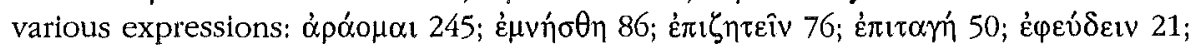

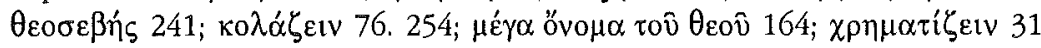

1) L. ACHEILARA, in $A D, 42$ B2 (1987) [1992], p. 481: A. presents a new honorific inscription for the orator and politician Potamon of Mytilene [see infra $\mathrm{n}^{\circ} 179$ ], honoured as benefactor, saviour, and ktistes of his city (1st c. AD). [AC]

*2) S.B. AlEshIRE, Asklepios at Athens: Epigraphic and Prosopographic Essays on the Athenian Healing Cults, Amsterdam, 1991 [BE 1992, 72. 241]: A. republishes (with 
many restorations and new readings) three texts related to the cult of Asklepios in Athens (p. 5-46): A fragment belonging to an inventory of dedications in the Asklepieion of Athens ( $I G \mathrm{II}^{2} 1534,274 / 73$ ) [cf. infra $\mathrm{n}^{\circ} 3$ ], a text regulating contracts for a stoa in the Asklepieion (IG $\mathrm{II}^{2} 1685,300 / 299 \mathrm{BC}$ ?), and a catalogue of Paianistai (IG $\mathrm{II}^{2} 2481$, ca. AD 190-200). A. demonstrates that the 'Inventory IV' (early 3rd c. BC) is a detailed description of the interior of Asklepios' temple at Athens, which offers valuable clues for the architecture, the cult statue, and the location of votive offerings of different kinds (anatomical dedications, typoi, i.e. plaques with representations of individuals, and coins). In two essays A. studies the prosopography of worshippers and priests of Asklepios in Athens (p. 49-220). Further studies (p. 223-247) are devoted to the prosopography of worshippers in the Amyneion at Athens (with reedition of $I G \mathrm{II}^{2} 4487$ ) and the Asklepieion at Zea. [AC]

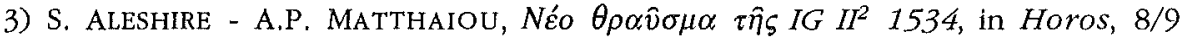
(1990/91) [1993], p. 45-51: Ed. pr. of a fragment belonging to an inventory of dedications in the Asklepieion of Athens (IG II ${ }^{2}$ 1534, 274/73) [for an English version of this article see supra $\mathrm{n}^{\circ} 2$, p. 5-11]. [AC]

4) G. ALFÖLDY, Epigraphische Notizen aus Kleinasien $I$. Ein Beneficium des Augustus in Ephesos, in ZPE, 87 (1991), p. 157-162 [BE 1992, 82. 405]: A. proposes to

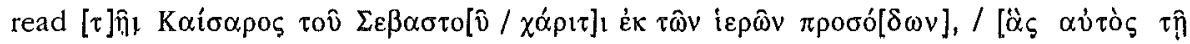
$\theta \varepsilon \alpha \underline{\alpha} \dot{\varepsilon} \chi \alpha \rho i \sigma \alpha \tau o$ in I.Ephesos $459(23 / 21 \mathrm{BC})$. According to A.'s interpretation, the inscription concerns the construction of a paved road, financed with the revenues of land donated or assigned to Artemis' sanctuary by Augustus, as part of the emperor's efforts to revive ancient cults [cf. G. ALFÖLDY, Augustus und die Inschriften: Tradition und Innovation. Die Geburt der imperialen Epigraphik, in Gymnasium, 98 (1991), p. 297]. [ES]

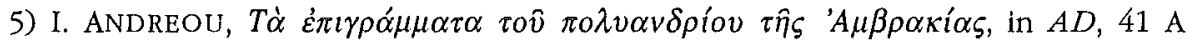
(1986) [1991], p. 425-445 [BE 1992, 19]: Ed. pr. of an epigram written on the grave monument erected for the Ambrakians killed in a sea-battle near the mouth of Arachthos (Ambrakia, 7th/6th c.) [cf, $A D, 41 \mathrm{~B}, 1986$ [1990], p. 104]. According to A.'s reading, the first line mentions the sacrifice of oxen for the dead (ö $v \delta \rho \alpha \varsigma[\tau] \circ \hat{v} \sigma \delta$ ' $[\dot{\varepsilon}] \sigma \lambda \circ \dot{v} \varsigma$

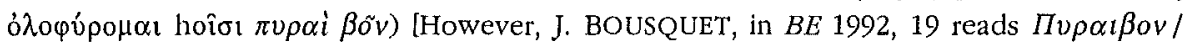
$\pi \alpha \hat{\imath} \delta \varepsilon \varsigma$ é $\mu_{\varepsilon \tau} \tau^{\prime} \sigma \alpha v \tau<0>\ldots \varphi$ óvov; reedition of the epigram: J. BOUSQUET, Deux épigrammes grecques, in $B C H, 116$ (1992), p. 596-606]. [AC]

6) I. ANDREOU, in $A D, 43 \mathrm{~B} 1,1988$ (1993), p. 308: A new dedication to the emperor Hadrian identified with Zeus Dodonaios (Nikopolis, 2nd c. AD) [cf. $E B G R$ 1987, 11]. [AC]

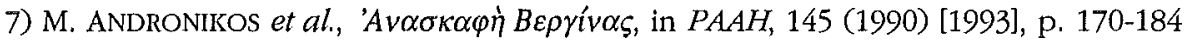
[cf. Ergon, 1990, p. 83-86]: A newly found sanctuary in Vergina (Aigai) may be attributed

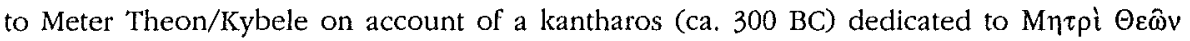

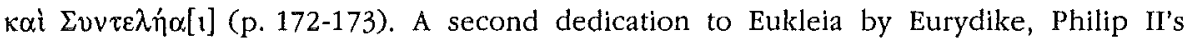
mother, was found in Eukleia's sanctuary (ca. 338 BC) [cf. $E B G R$ 1987, 99; on the goddess Eukleia, perhaps associated with Artemis, see E.N. BORZA, In the Shadow of Olympics, Princeton, 1990, p. 192-193; cf. SEG 40, 561]. [AC]

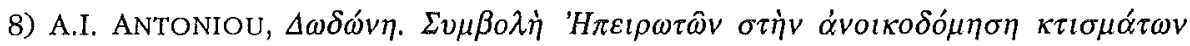

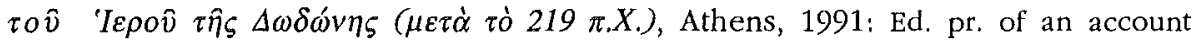
inscribed on a lead sheet and found in the sanctuary of Zeus in Dodona ( $3 \mathrm{rd} / 2 \mathrm{nd}$ c.) (first

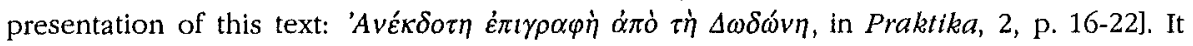


probably records the contributions of citizens of various Epirotic towns (the first 25 persons may be magistrates of various cities). The purpose of these contributions was probably to restore buildings in Zeus' sanctuary after its destruction in $219 \mathrm{BC}$. The text offers rich onomastic material (95 names, many of them attested for the first time in Epirus). [Notice the total absence of theophoric names; Hermon is perhaps the only exception]. [AC]

9) A. ARCHONTIDOU-ARgYri, in $A D, 41$ B (1986) [1991], p. 206 [BE 1992, 80; $S E G 40$,

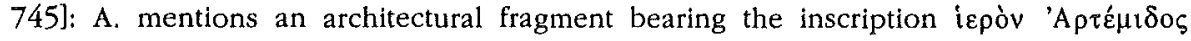
(Kornos on Lemnos), [ES]

10) G. ARGOUd, Réfection d'une fontaine et bains à l'Amphiaraion d'Oropos, in Praktika, 2, p. 26-30: Discussion of an Athenian decree and a contract concerning the repair of a fountain and a bath in the sanctuary of Amphiaraos at Oropos (ca. 338-333 BC;

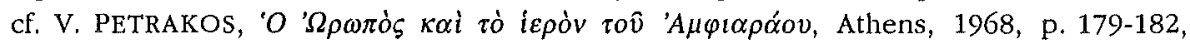
$n^{\circ} 40$ ). A. discusses certain archaeological aspects of the work carried out in the sanctuary. [AC]

11) P. AUPERT, Travaux de l'École Francaise à Amatbonte, in $B C H, 115$ (1991), p. 785: A decree from Amathous ( $L B W$ 8823, reign of Claudius) has been recovered. It attests the word $\pi \alpha \rho \alpha v v \mu \varphi 1 \alpha$, probably referring to the hieros gamos celebrated in the cult of Hera. [ES]

12) D. BAIN, Six Greek Verbs of Sexual Congress ( $\beta \imath v \hat{\omega}, \kappa \imath v \hat{\omega}, \pi v \gamma i \zeta \omega, \lambda \eta \kappa \hat{\omega}$, oí $\varphi \omega$, $\lambda \alpha t \kappa \alpha \dot{\zeta}(\omega)$, in $C l Q, 41$ (1991), p. 51-77 [BE 1992, 373]: In this interesting study on the Greek sexual vocabulary, $B$. comments occasionally on the use of these verbs in inscriptions of religious significance. Bıvô ('to have sexual intercourse') is used in a 5 th c. BC lex sacra from Olympia, which prohibits sexual intercourse in the sanctuary; oi $\varphi \omega$ ('to have sexual intercourse') is used in the 'pederastic' graffiti at the sanctuary of Apollon Delphinios in Thera (not necessarily in the context of an initiation ritual) [view expressed more recently by E. BRONGERSMA, in Joumal of Homosexuality, 20 (1990),

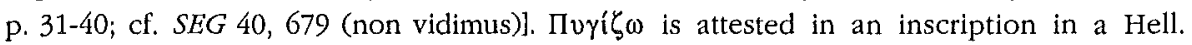

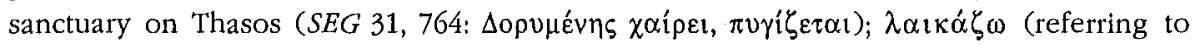
fellatio) may be restored on a clay votive plaque (Corinth, 6th c. BC, IG IV 313), probably having an apotropaic function (cf. the representation of an ithyphallic figure). The exact

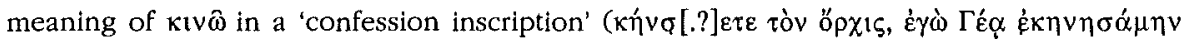
Ė $\pi$ i to $\chi$ (wóiov) is not clear (the text is republished now by G. PETZL, in EA, 22 (1994), $n^{\circ}$ 110. C. BRIXHE - A. PANAYOTOY, in $B E 1992,373$ prefer the meaning 'to move', without excluding the interpretation "me, I had intercourse with Gea in the sanctuary"]. B. also collects examples of the verb $\chi \dot{\varepsilon} \zeta \omega$ used in warnings against defecation of holy

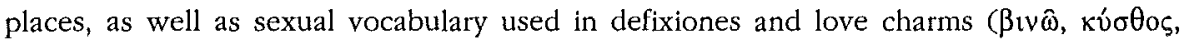
$\lambda \alpha \iota \kappa a ́ \zeta \omega, \pi \rho \omega \kappa \tau o ́ \varsigma, \sigma \tau v ́ \omega)$. [AC]

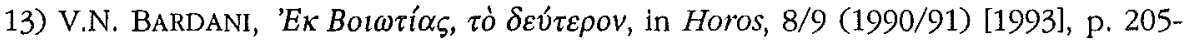
206: B. disagrees with the view expressed in $E B G R$ 1988, 10 that the phrase $\dot{\alpha} \gamma \omega v 0 \theta \varepsilon \tau 0 \hat{v} \tau$ os [name of the festival] to $\pi \rho \hat{\omega} \tau$ tov may refer to the first celebration of this unknown agon (Boiotia, ca, $50 \mathrm{BC}$ ); in that case we should expect the expessions

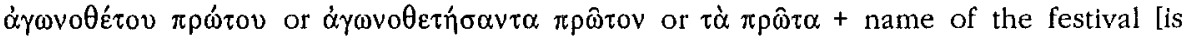
there really a difference ?]. B.'s alternative explanation is that the text was inscribed during the agonothetes' second term of office, and for this reason he had to add the 
expression tò $\pi \rho \hat{o ̂ \tau}$ rov. [But as B. admits (p. 206 note 4) there is no instance of recording that an official held an office for the first time, for the simple reason that nobody would have known if he was going to hold it for a second time. Only the iteration of office is recorded. The expression $\dot{\alpha} \gamma \omega v 0 \theta \varepsilon \tau 0 \hat{v} v \tau$ เ

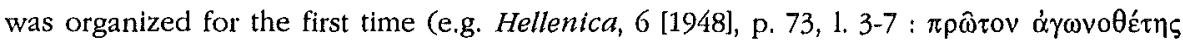

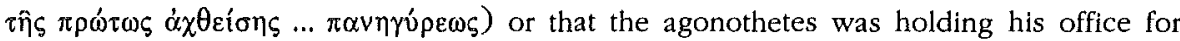
lifetime (cf. e.g. the agonothesia of the Meleagria at Balboura, infra $\mathrm{n}^{\circ} 163$ ), and this was his first term]. [AC]

*14) M. BEARD, Writing and Religion: Ancient Literacy and the Function of the Written Word in Roman Religion. Question: What was the Rôle of Writing in Graeco-Roman Religion?, in M. BEARD et al., Literacy in the Roman World, Ann Arbor, 1991, p. 35-58 [BE 1992, 464]: B. argues that we should not draw a sharp contrast between the function of the written word in paganism and in Christianity. The epigraphic and literary testimonia reveal the quantity of writing visible in sanctuaries (dedications, graffiti of pilgrims and visitors, records of healing miracles, vows, oracles) and the major role writing played in the organisation of religion and the recording of beliefs and cult prescriptions in the Roman world. $[\mathrm{AC}]$

15) G. BEJOR, Hierapolis. Scavt e Ricerche III. Le statue, Roma, 1991 [BE 1992, 105]: Publication of the statues from the theater, the sanctuary of Apollon, and the town of Hierapolis (imp.). Some of the statues found in the theater were inscribed (cf. T. RITTI, Hierapolis. Scavi e Ricerche I. Fonti letterarie, epigrapbiche ed archeologiche, Roma, 1985); the inscriptions on the statues of Apollon Kitharodos and Leto are published here for the first time (other statues include those of Apollon Kareios, Artemis, and Asklepios). In the sanctuary of Apollon, notice the dedication of a statue to the Theoi Sebastoi (i.e. the emperors) and the Demos $\left(\mathrm{n}^{\circ} 25\right),[\mathrm{AC}]$

16) E. BERNAND, Dédicace d'un illarque, in ZPE, 87 (1991), p. 53-55 [BE 1992, 560]: Ed. pr. of a dedicatory inscription from Egypt $(18 \mathrm{BC})$ by an ilarchos. The text mentions a prostates, perhaps the head of a cult association or the supervisor of a private sanctuary, belonging to the local military units. [ES]

17) E. Bernand, Dédicace de la région du Lac Mariout, in $Z P E, 87$ (1991), p. 56-58 [BE 1992, 566]: B. argues that $\theta \varepsilon \dot{\alpha} \mu \varepsilon \gamma i \sigma \tau \eta \dot{~ \varepsilon ́ v ~} \Pi^{2} v 1 \omega \ldots$ in a dedicatory inscription (SB 5073, Mariout, 2nd c. AD) may be identified with Isis. [ES]

18) E. BERNAND, Épitaphe d'un atblète d'Hermoupolis Magna, in ZPE, 87 (1991), p. 59-64 [ $B E$ 1992, 572]: Revision of a funerary inscription of an athlete, periodonikes, xystarches, and neokoros of Sarapis (SEG 18,692, Hermoupolis, after AD 212). Instead of the common funerary imprecation, this inscription exhorts the passers-by to take an oath that they will not violate the tomb. [ES]

19) P. BERNARD, Les rbyions de Nisa: à quoi, à qui ont-ils servi?, in P. BERNARD F. GRENET (eds.), Histoire et cultes de l'Asie Centrale préislamique. Sources écrites et documents archéologiques. Actes du Colloque international du CNRS (Paris, 2228 novembre 1988), Paris, 1991, p. 31-38 [BE 1993, 138]: B. argues conclusively that the Parthian rhyta of Nisa were not used in Parthian religious ceremonies or coronations, but in symposia; they were probably made for a Greek client in an area later conquered by the Parthians (late Hell.). The name of Hestia, which appears on one of the 
vases, should be interpreted as a drinking toast; B. gives (p. 37-38) a list of vases inscribed with similar toasts, usually with invocations of gods (Aphrodite, Athena, Demeter, Dionysos, Hermes, Hestia, Pan, Zeus Soter) and personifications related to drinking (Hedyoinos, Hedypotes, Oinopos, Pausikrepalos) or to the well-being of the symposiasts (Agathe Tyche, Agathos Theos, Agathos Daimon, Alypia, Anteros, Asphaleia, Eirene, Eros, Eunoia, Euploia/Euplous, Euthymia, Hedone, Hygie, Philia). [For an analysis of the representations on the rhyta of Nisa see P. CHUVIN, o.c., p. 23-29). [AC]

*20) P. BILDe, Atargatis/Dea Syria: Hellenization of Her Cult in the HellenisticRoman Period?, in Seleucid Kingdom, p. 151-187: B. offers an overall picture of the sources (mainly archaeological and literary) on the cult of Atargatis. Although the cult preserved certain indigenous elements, in the Hellenistic and Roman periods it can be regarded as hellenized. [ES]

21) M. BILE, Quelques termes religieux en crétois, in Hellenika Symmikta, p. 7-14: On the basis of the inscriptions from Lebena (Crete), B. examines certain terms related to the religious sphere [cf. $E B G R$ 1988, 15]: i $\alpha \rho o p \gamma$ ó (attested only in Gortyne, Lebena and

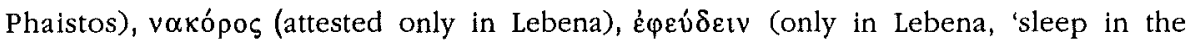

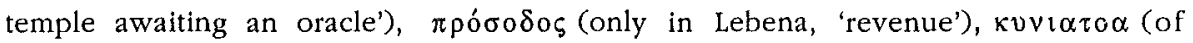
unknown origin and meaning, perhaps $\kappa v v \varepsilon \downarrow \alpha \zeta \hat{\omega} 1 \alpha$ ), $\tau \iota \alpha F \imath \lambda \lambda \alpha$ (also of unknown origin). On the basis of epigraphic and numismatic testimonia, B. distinguishes three chronological levels in the whorship of gods at Lebena: The cult of the Nymphs and Acheloos belongs to the first, the cult of Asklepios to the second, and the cult of Hermes, very popular throughout Crete, to the third level. [ES]

*22) J.M. BLAZQUEZ, L'élément grec dans les religions orientales dans la péninsule ibérique, in Praktika, 2, p. 77-81: Prosopography of worshippers bearing Greek names in Iberia. For the most part they were devotees of Oriental cults (Mithras, Kybele/ Magna Mater, Attis, Isis, Sarapis, Syrian deities, but also Nemesis). Many of them must have been slaves or freedmen. [AC]

23) W. BLÜMEL, Die Inschriften der Rhodiscben Peraia (ISGK, 38), Bonn, 1991 [BE 1992, 190. 454]: The corpus of the inscriptions from the Rhodian Peraia in Asia Minor includes a few new texts (marked with an asterisk) [cf. infra ${ }^{\circ}$ 28]. Dedications to: Aphrodite (104, 3rd/2nd c;; 504, Hell. ?), Apollon (by a priest: 8 , early 3rd c. BC; 9, early 3rd c. BC), Apollon Delios (204, Hell.), Apollon Karneios (203, Hell.), Apollon Pedageitnyos (105, Hell. ?), Artemis (254, Hell.), (Artemis) Soteira Bakchia (6, 4th/3rd c. BC; 7, 40 BC), Asklepios and Hygieia (610, Hell. ?), Asklepios ó żv 'E $\pi 1 \delta \alpha v ́ \rho \omega t$ (757, early Hell.), Demeter and Kore (252, 2nd c. BC), Dionysos Narthakophoros (4*, 4th/3rd c.), Eileithyia (106, Hell. ?), Eueteria (by an hierothytes: 51, imp.), Zeus Atabyrios (2, 3rd c. BC), Zeus Kataibates (202, 1st c. BC), Zeus Helios, Augustus, and the Demos (505, 1. 1st c.

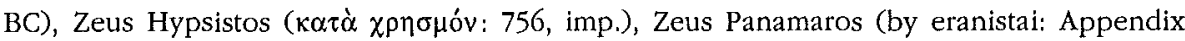
IV, 2nd c. BC), Hekate (503, 2nd c. BC; 586, Hell.), Hemithea (dedication of her temple: 451, ca. 300 BC), Herakles (141, 4th c. BC; 153, 3rd c. BC), Hermes and Herakles (783, 1st c. ?), Hermes, Herakles, and Helios (784, 1st c. BC ?), Hermes Propylaios (Appendix VI, 3rd c. BC), Leto (291, Hell.; 502, 4th c. BC), the Muses (304, late imp.). Leges sacrae: Sacrificial regulations of the sanctuary of Zeus Atabyrios $(1=L S S 109$, 3rd c. BC); prohibition against the removal of dedications from a sanctuary $(3=L S A M 74,3 \mathrm{rd} \mathrm{c} . \mathrm{BC})$, a decree of the Koinon of Tymnioi on cult-matters ( $201=$ LSS $111,2 \mathrm{nd} / 1 \mathrm{st}$ c.), a decree of 
Lindos about sacrifices to Enyalios (251, 440-420 BC), sacrificial regulations for the cult of Aphrodite (292 = LSS 110, imp.), fragment of a decree of Lindos concerning sacrifices in Physkos (501 = LSCG 143, $66 \mathrm{BC}$ ), regulations on the acquisition of priesthood of various deities in Hyllarima (Appendix V, 4th-2nd c. BC), a decree from Syrna for a foundation, providing for sacrifices to be offered to Asklepios (303, 2nd c. BC). Cult associations: Adoniastai, Apolloniastai, Soteriastai, Asklapiastai Aristodameioi (156, Hell. ?), Eranistai Adoniazontes (12,3rd/2nd c.), Adoniastai Aphrodeisiastai Asklapiastai, Heroistai Samothrakiastai in Aulai $(471,1$ st c. BC/1st c. AD), Asklepiastai (52, Hell.), Athaniastai $(302,3 \mathrm{rd} / 2 \mathrm{nd}$ c.), Dioskouriastai Theudoteioi (556, ca. $140 \mathrm{BC}$ ), Haliastai Polemokleioi (571, Hell.), Eranistai (155, Hell.). Officials: A priestess of Artemis Pergaia (21, Hell.), priests of Apollon Samnaios (358, 1st c. BC/1st c. AD), Apollon Pythios and Kedrieus (557, 1st c. BC), and Heros Abraikos? (758, Hell. ?); lists of priests of Asklepios (151, Thyssanous, 2nd c. BC), Leto and Aphrodite (608-609, Idyma, 2nd c. BC), Athena and Zeus Polieus, Aphrodite, Asklepios, and Sarapis (101, Phoinix, mid 3rd c. BC). Festivals: Pythia $(109,2$ nd c. BC). Sanctuarles: Epidoseis for the restoration of the temple of Dionysos (101, early 3rd c. BC), for the temple of Athena Kameiros (152, 3rd c. BC), and for the temple of Asklepios in Syrna (301, 3rd/2nd c. BC); a decree for the completion of the sanctuary at Kastabos (401, mid 2nd c. BC). [ES]

24) B. BÖTTGER - K. HALlof, Inschriften aus Karasura (II), in Klio, 73 (1991), p. $474-$ 488: Ed. pr. of four dedications from Karasura (territorium of Augusta Traiana, Moesia, 2nd-3rd c. AD). Three dedications in fulfillment of vows (3-5) do not mention a deity (the expression $\alpha \gamma \alpha \theta \hat{\eta} \mathbf{\imath} \tau \dot{x} \chi \eta \mathbf{r}$ is used in $\mathrm{n}^{\mathrm{os}} 4-5$ ); in one case a woman's vow was fulfilled by her children (4). $\mathrm{N}^{\circ} 6$ is an enigmatic dedication to Apollon Dauterenos, whose epitheton is new; it derives either from a toponym or rather from $\delta \alpha \hat{\tau} \tau \alpha$ ('garden herbs', HESYCH., s.v.) as the editors prefer; in the latter case, Apollon's cult would have a rural character [on epithets in -enos in Thrace see $E B G R$ 1990, 78]. The text reads (1. 5-13): of $\pi \varepsilon \rho \mathrm{i}$

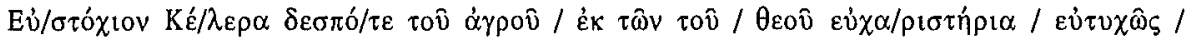
Kı $\sigma \alpha \zeta \eta v o t . H$. interprets the Kisazenol as unfree farmers settled on a plot belonging either to the family of Eustochios (already known as official and landlord in Philippoupolis) or (less probably) to a collegium of landowners under his

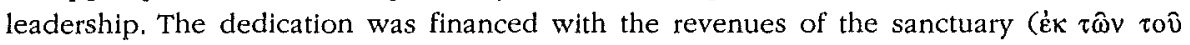
$\theta \varepsilon 0 \hat{v})$, which must have been situated on this land. [The payment of a thanksgiving dedication ( $\varepsilon \dot{v} \chi \alpha / \rho 1 \sigma \tau \dot{\eta} \rho 1 \alpha$ ) with the money of the addressee is astonishing. Should we suspect a mistake of the scribe ?]. [AC, ES]

*25) D. BONNEAU, Continuité et discontinuité nationale dans la terminologie religieuse du Nil d'après la documentation grecque, in Mélanges Bernand, p. 23-35: The epigraphic and papyrological material on the worship of the Nile (use of the word $\theta \varepsilon$ ć $\varsigma$ and its derivatives, genealogies of the Nile, subordination of the Nile to other deities, esp. Ammon) reveal the persistence of the river's sanctity from the Hell. to the Christian times, despite certain changes. [AC]

26) J. BORCHHARDT, Ein Ptolemaion in Limyra, in RA, 1991, p. 309-322 [BE 1993, 533]: A building excavated in 1985 in Limyra may be interpreted as a Ptolemaion. The epigraphic sources suggest that Ptolemaic troops saved Limyra from an invasion of the Galatians (p. 319); the shrine for the cult of the Ptolemies could have been built on that occasion. [AC] 
27) J. BousqueT, Inscriptions de Delphes, in BCH, 115 (1991), p. 167-181 [BE 1992, 30. 274]: Ed. pr. of 11 inscriptions from Delphi: 4) A fragmentary and enigmatic epigram seems to allude to the colonization of Alexandria. The text mentions Phemonoe and Eidothea; according to the literary tradition Phemonoe, was the daughter of Apollon and the first Pythia; the name Eidothea may be related to the Egyptian prophetess Eido/Theone, the daughter of Proteus. 6) Fragment of an Amphictyonic decree referring to the judicatory activity of the hieromnemones (3rd c. BC) [cf, the remarks of $\mathrm{Ph}$. GAUTHIER, in $B E$ 1992, 274]. [ES]

28) A. Bresson, Recueil des inscriptions de la Pérée rbodienne (Pérée intégrée), Paris, 1991 [BE 1992, 453]: This corpus includes already published inscriptions from the integrated part of the Rhodian Peraia. The texts are classified by region and a number of them have also been included in W. BLÜMELS's corpus (supra $\mathrm{n}^{\circ} 23$ ). Dedications to: Apollon (177, 4th c. BC), Apollon Delios (by the association of the Aphrodisiastai Soteriastai, 97, 2nd/1st c.), Apollon Pel---] (151, 3rd/2nd c.), Eileithyia (152, 3rd/2nd c.), Zeus Atabyrios (by Rhodian soldiers, 185, 3rd c. BC), Zeus Kataibates (104, 1st c. BC), Hekate (17, 1st c. BC; 18, imp.), Hemithea (39, 3rd cent. BC), Leto (20, 4th/3rd c.), (Artemis) Soteira Bakchia (200, ca. $150-51$ BC). Notice also the expression $\delta \hat{\omega} \rho \alpha$

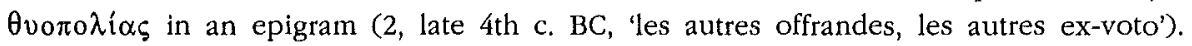
Leges sacrae: A decree of Lindos concerning the cults in Physkos $(22=L S C G 143,1$ st $\mathrm{c}$. BC), regulations about sacrifices offered to Aphrodite $(65=\operatorname{LSS} 110$, imp.), regulations about public order in the sanctuary of Zeus and Hera at Tymnos (102 $=$ LSS 111 , 2nd $/ 1$ st c.), sacrificial regulations of the cult of Zeus Atabyrios (186 = LSS 109, 3rd c. BC), regulations about public order in an unknown cult $(187=L S A M 74,3 \mathrm{rd}$ c. BC). Cult associations: Dioskouriastai Theudoteioi ( 7 , late 2nd c. BC), Adoniastai Aphrodeisiastai Asklapiastai in Aulai and Heroistai Samothrakiastai (57, 1st c. BC/1st c. AD), Adoniastai, Apolloniastai [---]stai Soteriastai and Asklapiastai Aristodameioi (126, Hell.), Strapiatai, a name which probably derives from the cult of Zeus Astrapatas (132, 1st c. AD), Asklapiastai (169, 1st c. BC), Adoniazontes (202, 2nd c. BC). Officials: A priestess of Artemis Pergaia (174, 4th c. BC); priests of Aphrodite (147, 3rd c. BC), Apollon (195, 3rd c. BC), Apollon Pythios and Kedrieus (3. 8, 2nd c. BC), Apollon Samnaios (54, 1st c. BC); lists of priests of Asklepios (Thyssanous, 118, $3 \mathrm{rd} / 2 \mathrm{nd} \mathrm{c}$ ). Athena and Zeus Polieus, Aphrodite, Asklepios, and Sarapis (Phoinix, 148, 3rd c. BC); an hierothytes (8, 2nd c. BC), an hierothytes of Eueteria (172, imp.), hieromnamones (responsible for the leasing of land in Amos, 49-50, late 3rd c. BC), hieropoioi in Phoinix (148, 3rd c. BC), a gymnasiarchos of Apollon (181, unknown date). Festivals: Pythia (150, 3rd c. BC), Adonia (202, 2nd c. BC). Sanctuaries: A dedication by two architects on the occasion of the construction of a temple $(37,4 \mathrm{th} / 3 \mathrm{rd} \mathrm{c}$. BC), an inventory of a sanctuary at Amos (48, late 3rd c. $\mathrm{BC}$ ), a fragmentary list of contributors for the construction of the temple of Asklepios at Syrna $(58,3 \mathrm{rd} / 2 \mathrm{nd}$ c.), a decree of Syrna about a donation of land to the temple of Asklepios (59, 2nd c. BC), a decree concerning the construction of the temple of Athena Kameiris $(122,3 \mathrm{rd} \mathrm{c.} \mathrm{BC})$, an epidosis-decree for the construction of the temple of Dionysos at Phoinix (149, 3rd c. BC), a fragmentary decree of Bybassos for a benefactor of the sanctuary of Hemithea at Kastabos (44, 2nd c. BC). [In the last text $\mathrm{cf}$. the remarks of C. BRIXHE - A. PANAYOTOU, in BE 1992, 453: They support the restoration

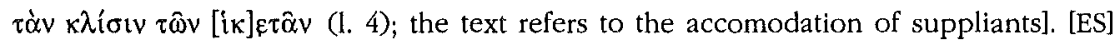


29) P. BRUN, Les Lagides à Lesbos: essat de cbronologie, in $Z P E, 85$ (1991), p. 99113: In this thorough study of the Ptolemaic presence on Lesbos, $B$. republishes an honorific decree (IG XII Suppl. 115) for a priest of Ptolemy II Philadelphos (ca. 267-260). [ES]

30) PH. BrunEau, Deliaca (IX), in BCH, 115 (1991), p. 377-388 [BE 1992, 79. 114]: 1) B. argues that ARISTOPH., $\operatorname{Pax} 1.873-876$ refers to the festival Brauronia, celebrated in Brauron (not in Athens or in Delos). It belonged to the five penteteric festivals mentioned by ARISTOT., Athen. Pol. 54, 7. 2), In a critical review of H. MEYER's article about the sanctuary and the cults of the Poseidoniastai from Berytus (in $A M, 103,1988$, p. 203 ss.) B. strengthens his view that there was no worship of a Berytian 'trias', but of a 'dyas'; he also argues that the cult of Roma was established at a much earlier date than 88 BC. [ES]

31) M. BÜJÜKKOLANCI - H. ENGELMANN, Inschriften aus Ephesos, in ZPE, 86 (1991), p. 137-144 [BE 1992, 409]: Ed. pr. of 11 inscriptions from Ephesos, 1) A fragmentary inscription mentioning an order given by Artemis (ì $\theta \varepsilon \dot{s} \varsigma \dot{\varepsilon} \kappa \varepsilon ́[\lambda \varepsilon v \sigma \varepsilon v]$ (arch. ?). 2) A fragmentary inscription mentioning the word $\tau \dot{\alpha} \dot{\varepsilon} \pi \mu \eta \dot{\eta} v i \alpha$ (class.). 10) An inscribed altar dedicated to Asklepios and Hygieia by Zosimos, who suffered from chronic headaches and an eye disease (imp.); the verb $\chi \rho \eta \mu \alpha \tau i \zeta \varepsilon I v$ is used for the dedication of the altar, an expression well documented in religious contexts. 11) An altar dedicated in fulfillment of a vow (imp.). [ES]

32) L. BuRN, The Inscribed 'Step' from the Road North of the 'Bastion', in D.M. BAILEY et al., Excavations at El-Ashmunein, IV. Hermopolis Magna: Buildings of the Roman Period, London, 1991, p. 62 [BE 1992, 571]: Reedition of SEG 36, 1395 (Hermopolis), a dedication to Agathe Tyche, which records a holy day ( $\left(\varepsilon^{\prime} \alpha \Sigma \varepsilon \beta \alpha \sigma \tau \eta \dot{n}, s c\right.$. $\dot{\eta} \mu \varepsilon^{\prime} \rho \alpha$ ), celebrated in honor of the emperor Tiberius (his birthday ?). [AC]

33) P. CABAnEs, Les inscriptions d'Épire, in Praktika, 2, p. 107-112: Report about the progress of the work on the corpus of the inscriptions of Epirus. It includes the brief presentation (p.110) of an unpublished inscription from Bouthrotos mentioning an eponymous priest of Asklepios (Hell.). [AC]

34) P. Cabanes, Un Phrygien à Dyrrbachion, in Mélanges Bernand, p. 55-59; Ed. pr. of the grave epigram for a Phrygian buried in Dyrrhachion (imp.). The epitaph ends with

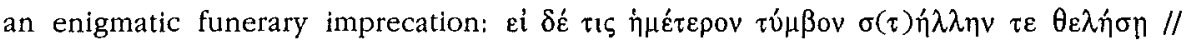
$\sigma \kappa \hat{v} \lambda_{\alpha \imath} / \dot{\varepsilon} v \dot{\alpha} \lambda \lambda_{0} \delta \alpha \pi n \hat{~ \tau o i ̂ \alpha ~ T E K H K \Lambda O / ~ i ́ \delta o t: ~ " I l ~ s ' a g i t ~ d e ~ s o u h a i t e r ~ p o u r ~ l e ~ m a l f a i t e u r ~ q u i ~}$ porterait atteinte à la tombe et au monument qu'il voit $\dot{\varepsilon} v \dot{\alpha} \lambda \lambda_{0} \delta \alpha \pi \hat{n}$, en terre étrangere, la vengeance des dieux". C. speculates whether one should read the abbreviated word $\tau \varepsilon ́ k(v \alpha)$, i.e. "qu'il voit (pour ses enfants de tels vols?)". [More persuasive is S. FOLLET's

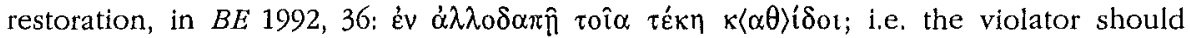
lose his own children in foreign lands]. Such imprecations were very common in Phrygia. [AC]

35) P. CABANES, Recherches épigraphiques en Albanie: péripolarches et peripoloi en Grèce du Nord-Ouest et en Illyrie à la période bellénistique, in CRAI, 1991, p. 197224 [ $B E$ 1992, 294]: Most of the inscriptions related to the activities of peripolarchoi in northwest Greece and Illyria ( $3 \mathrm{rd}-2 \mathrm{nd}$ c.) are dedications to various deities, usually the 
most important local deity: Pan and the Nymphs (Korykian cave, on Mt. Parnassos), Artemis (Medeon), Dionysos (Apollonia). [ES]

36) F. CAIRNS, The "Laws of Eretria" (IG XII.9 1273 and 1274): Epigrapbic, Legal, Historical, and Political Aspects, in Phoenix, 45 (1991), p. 296-313: Restoration and discussion of early Eretrian laws (ca. 525-500, IG XII 9, 1273-1274). C. makes the plausible argument that the oath referred to in the first clause in a judiciary context is the oath taken by the judge or arbiter before awarding the penalty (not the oath of the defendant or the plaintiff cf. the Gortynian Code). [AC]

37) W.M. CALDER III, Paul Maas on IG II 2940, 13199, in Mnemosyne, 44 (1991), p. 439: In the margin of his copy of W. PEEK's, Attische Inscbriften, in MDAI(A), 67 (1942), p. 1-229 P. MAAS had proposed the following restoration of $I G \mathrm{II}^{2} 29401.1-2$ (Athens, 4th

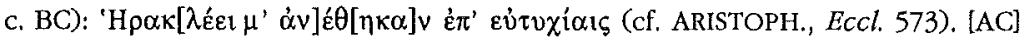

*38) G. CASAdIo, La metampsicosi tra Orfeo e Pitagora, in Orphisme, p. 119-155: In his thorough study on the development of the idea of rebirth in archaic Greece, C. discusses briefly the epigraphic sources for this idea (Orphic leaf from Thurioi, 4 th/3rd c., grave stele from Pantikapaion, 1st c. BC/AD). [AC]

39) H.W. CATLING, Zeus Messapeus Near Sparta: An Interim Report, in $\Lambda \alpha \kappa \omega v \imath \kappa \alpha i$ $\Sigma \pi 0 v \delta \alpha i, 10$ (1990), p. 276-295 [SEG 40, 358]: Presentation of the results of the excavation in a small sanctuary in Lakonia, which has been identified as a shrine of Zeus Messapeus on the basis of epigraphic evidence [cf. $E B G R$ 1990, 51]. The shrine existed since the 8th $\mathrm{c}$. BC. The finds include handmade terracotta statuettes of ithyphallic men. $[\mathrm{AC}]$

40) A.V. ÇELGIN - G. ÇELGIN - B. IPLIKÇIOĞLU, Antik Termessos kenti ve çevresinde eptgrafya arastirmalari, in AST, IX (1991), p. 193-202 [BE 1993, 586]: Ed. pr. of an agonistic inscription attesting an agon organised by the parents of two $\pi$ pó $\mu$ orpor, a dedication to Kakasbos, and five epitaphs with funerary imprecations and prohibitions; in three cases the fine was to be paid to Zeus Solymeus (Termessos, imp.). [ES]

41) A. CHANIOTIS, Habgierige Götter - habgierige Städte: Heiligtumsbesitz und Gebietsanspruch in den kretischen Staatsverträgen, in Ktèma, 13 (1988) [1992], p. 21-39 [BE 1993, 399; SEG 40, 768]: Three Hell. treaties between Cretan cities treat the status of sanctuaries situated on or near the common border in three different ways: a) The sanctuary of Ares and Aphrodite, disputed between Lato and Olus, passed under the control of the city on whose territory it was located (i.e. Lato); the sacred land was thus regarded as part of the Latian territory. b) The sanctuary of Hermes Kornisaios is mentioned in a treaty between Hierapytna and Lato. Although it is not clear whether it was located on the Latian terrirory or on 'no-man's land', the treaty gave the Hierapytnians the right to offer sacrifices in this sanctuary. [PH. GAUTHIER, in BE 1993, 399 doubts if this clause implies that only the Hierapytnians had the right to offer sacrifices there and if this sanctuary was located on 'no-man's land']. c) The dispute between Hierapytna and Itanos concerned the sacred land of Zeus Diktaios. According to the Hierapytnians the disputed land was sacred land; according to the Itanians it was part of their territory. But neither side disputed the fact that Zeus' sanctuary possessed

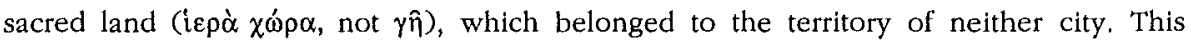
specific status of Zeus' sacred land probably derived from the fact that the sanctuary originally was the religious center of an amphictiony. The epigraphic evidence from 
other Cretan sanctuaries (treaties, dedications, inscriptions referring to building activities: Poseidon's sanctuary on Mt. Juktas, sanctuary of Hermes Kedrites in Simi Biannou, Idaean cave of Zeus) imply that until Hell. times certain cult places, always with a pre-Dorian past and always situated on the border between two or more cities, did not belong to the territory of a single city, but possessed their own hiera chora and served as religious centers of local amphictionies. [AC]

*42) A. CHANIOTIS, Gedenktage der Griechen. Ibre Bedeutung für das Gescbichtsbewußtsein griechischer Poleis, in J. ASSMANN (ed.), Das Fest und das Heilige. Religiöse Kontrapunkte zur Alltagswelt (Studien zum Versteben fremder Religionen, 1), Gütersloh, 1991, p. 123-145: Study of historical anniversaries in the Greek cities ( 5 th c. BC-5th c. AD). These festivals were established for the commemoration of various historical events (military victories, liberation from tyrants and foreign garrisons, peace treaties, concord after civil wars). Their program and rituals derived directly from that of religious festivals (stephanephoria, procession, sacrifice, prayer, singing of hymns, banquet, agon); the religious background of these political celebrations can also be seen in the alleged contribution of gods to the historical event and the heroisation of historical personalities. Through the active participation of the community, the speeches, and occasionally the dramatic representation of the historical event, the commemorative anniversaries contributed significantly to the integration of the Greek cities, their selfrepresentation, and the acculturation of their youth, especially in the cosmopolitism of the Hellenistic and imperial times. [AC]

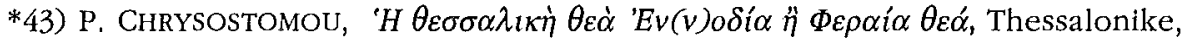
1991: Thorough study of the cult and iconography of the Thessalian goddess En(n)odia; C. discusses the diffusion of her cult in Thessaly (esp. Pherai and Pagasai), Macedonia, and other Greek regions (p. 29-149), and her various epithets (p. 175-235). He also presents a collection of the epigraphic testimonies (p. 175-192). [AC]

44) M. Cicikova, Graffiti sur céramique de Seutbopolis, in Praktika, 2, p. 130-133: General presentation of the ca. 140 graffiti on pottery from Seuthopolis (late 4th-3rd c.), among them dedications to gods (Zeus, Herakles, Hera?, Zeus Kabeiros?) [cf. K. LEHMANN, Samothrace 2.II. The Inscriptions on Ceramics and Minor Objects, New York, 1960, p. 17 notes 43-44] and sherds bearing signs with possible magical significance. [AC]

45) C.W. Clairmont, Zwei inedita, in M. GNADE (ed.), Stips Votiva. Papers Presented to C.M. Stibbe, Amsterdam, 1991, p. 47-49: Ed. pr. of a funerary epigram with obvious Homeric reminiscences in a private collection (ca. 375-350). The deceased,

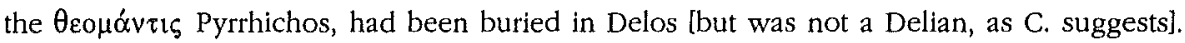
[ES]

* 46) S.G. COLE, Epigraphical Evidence for the History of Dionysiac Cult, in Praktika, 2, p. 255-258 [BE 1993, 407]: C. underlines the significant (but often neglected) contribution of inscriptions to or knowledge of Dionysiac cult, with special emphasis on inscriptions from Asia Minor (Magnesia on the Maeander, Halikarnassos, Phrygia). [AC]

*47) S.G. COLE, Dionysiac Mysteries in Pbrygia in the Imperial Period, in EA, 17 (1991), p. 41-49 [BE 1992, 483]: C. republishes a grave altar dedicated to the hierophantes Telesphoros by his wife, his children, and an association of Dionysiac 
worshippers ( $\varepsilon i \varepsilon \rho \grave{\alpha} \varepsilon \dot{i} \sigma \varepsilon \varepsilon \hat{\imath} \rho \alpha=i \varepsilon \rho \dot{\alpha} \sigma \pi \varepsilon \hat{\imath} \rho \alpha$ ) in Akmonia (Phrygia, 3rd c. AD); the relief on the altar shows a figure holding a thyrsos. A direct parallel can be seen in an altar from Dorylaion, dedicated to Dionysos by Zotikos for his own protection and for the security of "the Bakchos" (an official of a cult association ?); the altar bears relief representations of a figure with thyrsos, a female figure (a maenad ?), a bucranion, a snake, and a vine branch growing from a vessel. Similar decoration can be restored on the altar from Akmonia. The figures holding thyrsoi may represent Dionysiac worshippers, probably the persons mentioned in the inscriptions. Recent research excludes the possibility of a Phrygian origin of Dionysos' cult in Greece. However, the epigraphic and archaeological evidence shows that Dionysiac associations and cult practices were widespread in Phrygia in imperial times (basically after the 2nd c. $A D$ ). [AC]

48) T. CORSTEN, Neue Denkmäler aus Bithynien, in EA, 17 (1991), p. $79-99$ [BE 1992, 495]: Ed. pr. of inscriptions from West Bithynia. Pylai: An honorific inscription for an official who had dedicated a statue of Demos; on that year the eponymous office of the hieromnamon was held by the Roman senate $(1,2$ nd c. AD); a dedication to Theol Epekooi (2). Kios: C. publishes the grave inscription of a slave as follows: $\Sigma \dot{v} v \varphi$ opos $\tau \dot{\eta} \nu \sigma \tau \dot{\eta} \lambda(\eta v)$

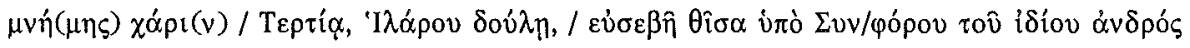

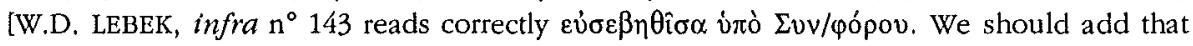

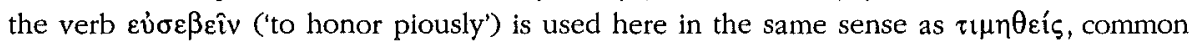

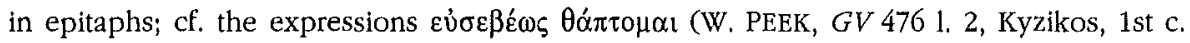

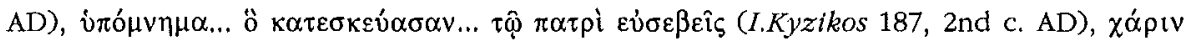

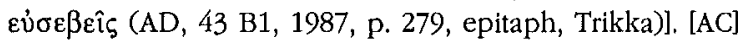

*49) T. CORSTEN, Herodot I 131 und die Einfilhrung des Anabita-Kultes in Lydia, in Iranica Antiqua, 26 (1991), p. 163-180 [BE 1993, 184]: Based on HEROD. 1, 131, the archaeological evidence, and a few (basically late) epigraphic sources, C. reconstructs the way the cult of Anahita was introduced to Lydia. Her cult was introduced through private initiative (cf. the foundation of Zeus' cult by Baradates); and only in the middle of the 4th c., under the reign of Artaxerxes II, did it receive royal support. Initially, Anahita was identified with Meter (Kybele), and the Greeks associated her with Aphrodite. This accounts for Herodotus' (false) information that Anahita's Persian name was Mitra: Herodotus' informant wanted to tell him that the Persian name for the Greek Aphrodite was Meter (i.e. Anahita), but mispronounced the name (Metra>Mitra in Herodotus' mss.). The identification of Anahita with Artemis is a late development (after the $3 \mathrm{rd} \mathrm{c.} \mathrm{BC}$ ). [AC]

50) T. CORSTEn, Die Inscbriften von Prusa ad Olympum (IGSK, 39), Bonn, 1991 [BE 1992, 616; $B E$ 1993, 560]: The corpus of the inscriptions of Prusa includes a considerable number of new texts (marked with an asterisk). Dedications to: Apollon Libotenos (40, Hell./ imp., the epithet is attested only here), Apollon Soter (41, imp.), the local deity Tataula, probably to be identified with Apollon, as the dedicated statue implies $(42 *$,

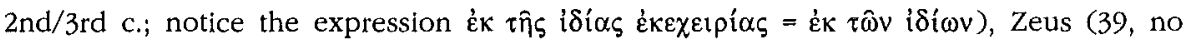
date), Nemesis (by a gladiator: 45, imp.), Hermes, Sarapis, and Isis (by a cult association of mystai and dekadistai: 48, 2nd c. AD), Heros (46*, Hell./imp.), Hosion kai Dikaion (by the kome Sarkotyle: 49*, early imp.) [on these deities cf. infra $\mathrm{n}^{\text {os }} 202$. 204], Kybele (in fulfillment of a proclamation: 50,2 nd c. $A D$ ), and a snake god (in fulfillment of an غ̇лıน 44 , no date). No $43^{*}$ ( $2 \mathrm{nd} / 3 \mathrm{rd}$ c.) refers to the restoration of a temple by the kome of 
Tataulenoi (probably for the local god Tataula). Two honorific inscriptions mention persons who held the offices of the priest of the imperial cult, agonothetes, and Pontarches (13, early 2nd c. AD), and the priest of Zeus Olympios, agonothetes, and panegyriarches $\left(22,1 \mathrm{st} / 2\right.$ nd $\left.\mathrm{c}_{\text {. }}\right)$. [ES]

51) M.-TH. Covilloud-Le DinaHeT, L'exploitation des domaines d'Apollon et le ravitaillement de Délos, in M.-M. MACTOUX - E. GENY (eds.), Mélanges Lévêque. 4. Religion, Paris, 1991, p. 115-140 [BE 1992, 333; SEG 40, 644]: The author studies the documents related to the exploitation of Apollon's sacred land as a source for the economic history of Delos in the 3rd c. BC. The rents for the estates and the prices of agricultural products recorded in the Delian accounts lead to the conclusion, that the financial situation of the Delian citizens was not as critical as suggested by G. GLOTZ and J.A. LARSEN. A public grain fund helped the Delians survive periods of high prices. [ES]

52) M.-L. CREMER, Ein Votiv für Zeus Thallos, in Asia Minor Studien, 3 (1991), p. 125128: C. studies a fragmentary relief dedicated to Zeus Thallos (Phrygia, 3rd c. AD) [EBGR 1988 , 84]. According to her reconstruction, the central medallion represented Zeus Thallos (not the dedicant); his bust was surrounded by grapes, a symbol of fertility, and was flanked by two smaller busts of Kybele and Zeus Helios. [AC]

53) M.-L. CREMER, Hellenistisch-römische Grabstelen im nordwestlichen Kleinasien. 1. Mysien (Asia Minor Studien, 4.1), Bonn, 1991 [BE 1992, 34; BE 1993, 421]: The first part of a study dedicated to the grave stelae of the Hell. and imp. times in NW Asia Minor presents the material from Mysia (Kyzikos and Miletopolis, 4th c. BC-4h c. AD). C, offers a detailed study of the iconography, which combines Attic and Oriental components; the motifs include hunting scenes, chariot races, riding women and men, branches, dancers, ships, peasants, and funerary banquets. The catalogue (p. 121-196) includes some unpublished monuments, but (with a few exceptions) the inscriptions were already known. Since the focus of the study concerns iconography, C. does not give an epigraphic commentary, but her corpus provides a nice collection of grave inscriptions. Some of them (almost exclusively metrical texts) express thoughts about death and the underworld (KS 7, KN 17. 18, 24, KH 5. 8, KM 1, KSt 20. 39, KB 11, MiSt 16, MiKSt 10, UMiS 4. 11) or about life after death (MiSt24 = W. PEEK, GV $718=$ I.Kyzikos 64: évi $\pi \alpha 1 \sigma i$ $\left.\kappa \dot{\alpha} \theta \eta \mu \alpha_{1}[\dot{\alpha}] \theta \alpha v \alpha \dot{\alpha} \tau \omega\right)$. Some of the grave inscriptions contain imprecations against violators of the tombs (MiK5, MiKSt 7. 10). One grave inscription mentions the honour

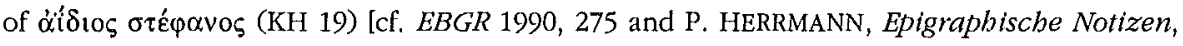
in $E A, 20$ (1992), p. 71]. MiKSt3 (SEG 35, 1285) attests the care given to the grave $\left(=\dot{p o \delta} \_\right.$oó $\varsigma$ ). Also notice a dedication to Apollon Krateanos (KV 2). [Cf. the remarks of C. BRIXHE - A. PANAYOTOU, in BE 1993, 421 on onomastics and the terms $\tau u \mu \beta 0 \times \lambda e ́ \pi \tau n \varsigma$ (KN 24) and $\lambda \alpha \mu \pi \alpha \delta$ เоко́лоৎ (maker of torches, KN 1)]. [AC]

*54) Y. DAcosta, Initiations et sociétés secrètes dans l'antiquité gréco-romaine, Paris, 1991: D. studies the nature and function of initiatory associations in Greece (mainly 6th-4th c. BC). Through the interpretation of the myth of the Minotaure, the Eleusinian initiation rites, and the cults of Kybele and Attis, D. attempts to show that the initiation was of central importance for the formation of Greek elites. [ES]

55) S.I. DAKARIS, 'A $\alpha \alpha \sigma \kappa \alpha \varphi \dot{\eta} \triangle \omega \delta \omega v \eta \zeta$, in PAAH, 144 (1989) [1992], p. 176-184 [BE 1993, 83]: D. presents an inscription found in the prytaneion of Dodone bestowing honors

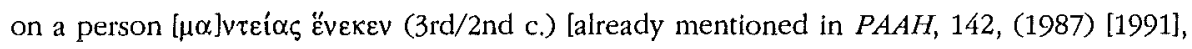


p. 118-122. As M. SÈVE, in $B E 1993,83$ rightly points out, it is a dedication and not a decree]. [AC]

56) G. DAUX, Problèmes delphiques d'architecture et d'épigrapbie, in RA, 1989, p. 23-64: Three studies on the topography of the sanctuary at Delphi: a) The selides in Apollon's temple are the ceiling slabs set on the side-galleries of the peristyle, which

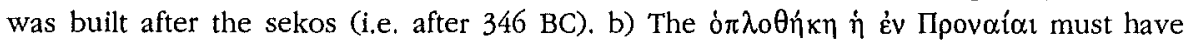
stood on the unexplored upper terrace of the sanctuary. c) The double oikos of Athena may have been a double temple or a hestiatorion with two rooms. [AC]

*57) M. Del Amor Lopez Jimeno, Las tabellae defixionis de la Sicilia griega, Amsterdam, 1991: Collection and reedition (with translation and bibliography) of all known defixiones (40 texts) from Sicily (5th c. BC-2nd c. AD) [cf. $E B G R 1989,6.29$ ]. The presentation of each text includes a commentary and remarks about the alphabet and the language. D. points to the differences between the Sicilian and the other defixiones (e.g. the use of $\gamma p \alpha \dot{\alpha} \varphi \omega$ and its derivatives, instead of the Attic $\kappa \alpha \tau \alpha \delta \varepsilon \omega$, the rare invocation of deities, the fact that usually the reasons for the cursing are not stated). [ES]

58) P.S. Derow, Pharos and Rome, in ZPE, 88 (1991), p. 261-271: Reedition (with historical commentary) of two decrees of Pharos and Paros (SEG 23, 489, ca. 219 BC), which also refers to a consultation of Delphi by the Parians; the oracle is only partly preserved. [ES]

59) N. Dimopoulou-Rhethemiotaki, in $A D, 42 \mathrm{~B} 2$ (1987) [1992], p. 530: A dedication to the Kouretes, protectors of livestock, was found in Karnari (near Archanes, Crete, imp.). [AC]

60) G. DONTAS, The True Aglaurion: A New Inscription From the Peripatos of Athens, in Praktika, 2, p. 147-150: D. presents (in translation) an Attic decree (3rd c. $\mathrm{BC}$ ), which praises the priestess of Aglauros and concerns regulations for the sacrifice eioıńpı $\alpha$ offered to Agraulos, Ares, Helios, the Horai, and Apollon [cf. EBGR 1990, 227]. The fact that the stele was found approximately at its original position leads to a new localization of the Aglaurion: It was not located to the north of the Acropolis, but to the east. [ES]

61) M. DREW-BEAR, La triade du rocber d'Akôris, in Mélanges Bernand, p. 227-234: On account of the epigraphic testimonia from Akoris [cf. $E B G R$ 1988, 13], D. interprets the rock-relief triad of Akoris as a representation of Helen, Kastor, and Polydeukes, assimilated to Isis and the two crocodile-gods. Isis' epithet Mochias can be restored in I.Akoris 10. [AC]

62) J. Ducat, Esclaves au Ténare, in M.-M. Mactoux - E. Geny (eds.), Mélanges P. Lévêque 4. Religion, Paris, 1990, p. 173-193 [SEG 40, 356]: D. examines the dossier of manumissions from Tainaron (Lakonia), focusing on the problems of the chronology and the exact nature of the inscriptions (manumissions or consecrations of slaves?). D. argues that such a strict distinction can not be made, since a conditional manumission (e,g. dependent on services to be provided to the private cults of the slave's owner) may be considered as a sort of hierodoulia similar to the consecration of slaves. In both cases the legal status of the consecrated freedman remains unclear and may differ from region to region. The only argument which rather strengthens the hypothesis of a consecration of 
the slaves is the considerable number of epigrams of hieroi and hierai found in Messenia and Lakonia. [ES]

*63) F. Dunand, Miracles et guérisons en Égypte tardive, in Mélanges Bernand, p. 235-250: The references to healing miracles in early hagiographic sources from Egypt should be seen in the light of the coexistence of Christian and pagan traditions, esp. the worship of traditional healing deities (Zeus Sarapis Asklepios Iatros, Imhotep, Hygieia, Amenhotep). [AC]

*64) G.E. DUNKEL, Vater Himmels Gattin, in Die Sprache, 34 (1989-1990) [1991], p. 126 [BE 1993, 592]: In this excellent study on the Indo-european pantheon, D. treats on a comparative basis the 'sacred family', represented in Greek religion by Zeus, Diwijal Dione/Hera, Eos/Aphrodite, and the Dioskouroi. He analyses the form and function of their names, and their historical evolution, underlining the absence - at least at the beginning - of an individual name for the 'wife' of the primary male deity. Later, a derivation from the name of the male deity $(\Delta i \alpha \varsigma)$ was used to designate the female deity (diwija, attested in the Linear B tablets, or Dione). In addition to the Vesda-texts and the early Greek literary tradition (Homer, Hesiod), D. makes use of the Linear B tablets and epigraphic material from Crete (I.Cret. I, xvi 24, dedication to Dione, Lato, Hell.) and Pamphylia (C. BRIXHE, Le dialecte grec de Pampbylie, Paris, 1976, $\mathrm{n}^{\circ} 134$, Aspendos, 2nd c. $B C$ ). In the latter text $D$. reads $\Delta \mathrm{t} F \dot{\omega} \vee \alpha \varsigma$ ('of Dione'), instead of $\Delta \mathrm{t} F \omega v \hat{\alpha} \varsigma$ (personal name) [cf. H. BRANDT, Kulte in Aspendos, in MDAI(I), 38 (1991), p. 247 note 97; SEG 38, 1339]. [ES]

65) S. DuSANIC, Épiménide le Cnossien et les thèmes bistorico-politiques des Lois de Platon à propos de l'inscription IG II , 4968, in Epigrapbica, 53 (1991) [1992], p. 25-57 [SEG 40, 209]: D. reedits a fragmentary inscription from Athens (IG $\mathrm{II}^{2}$ 4968) with the text of a metrical oracle, which alludes to the danger of a foreign invasion (ca. $350 \mathrm{BC}$ ). In D.'s opinion the historial situation alluded in the oracle was the Carian expansion under Maussolos, which threatened both Athens and Crete. Based on contemporary literary sources (esp. PLATO's Laws) D. attributes this oracle to the legendary Cretan seer Epimenides, who not only purified Athens from the Cylonian sacrilege, but also arranged for an alliance between Athens and Knosos. [AC]

66) K.T. ERIM - R.R.R. SMITH, Sculptures from the Theatre: A Preliminary Report, in Aphrodisias Papers, 2, p. 67-98 [BE 1992, 436]: Presentation of an inscription recording the dedication of a statue of Demos to Aphrodite, the emperors, and the Demos $\left(\mathrm{n}^{\circ}\right.$ 6, Aphrodisias, $\left.1 \mathrm{st} \mathrm{c} . \mathrm{AD}\right)$. [AC]

67) A. ERSKINE, Rhodes and Augustus, in ZPE, 88 (1991), p. 271-275 [BE 1992, 338]:

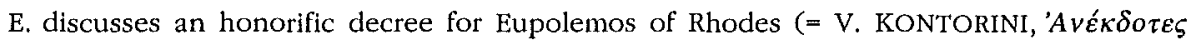

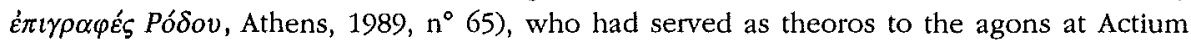
and Alexandria and envoy to Augustus. The decree illuminates the efforts of Rhodes to restore its relations with Augustus. The establishment of Augustus' cult and the official recognition of agons celebrating his victory at Actium should be seen in this context. [ES]

*68) C.A. FARAONE, Binding und Burying the Forces of Evil: The Defensive Use of "Voodoo Dolls" in Ancient Greece, in ClAnt, 10 (1991), p. 165-205 [BE 1993, 598]:

F. offers a comparative analysis of the binding rituals and the 'voodoo dolls' used for these purposes, making extensive use of inscriptions. In his discussion of the use of the 


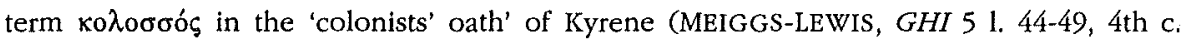
BC) [cf. $E B G R$ 1990, 192] and the 'cathartic inscription' of Kyrene (LSS 115 B 36. 39, 4th c. $\mathrm{BC})$ he observes that the terminology of the ghost-banning rite in Kyrene is partly

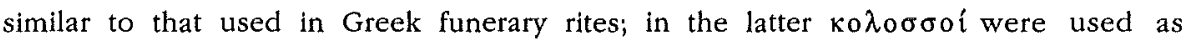
substitutes for reburial, F. also discusses a ritual described in the oracle of Syedra (1st $c$. BC) [infra $n^{\circ} 169$ ] (dressing an image of Ares, binding it in the "iron chains of Hermes", placing it in the center of the city, and offering sacrifices) in the light of ancient magic. [ES]

*69) C.A. FARAONE, The Agonistic Context of Early Greek Binding Spells, in Magika Hiera, p. 3-32: F. studies the various formulae used in early Greek defixiones in an attempt to define their function and social context in early Greek society. The formulae, of which F. distinguishes four groups (direct binding formula, prayer formula, wish formula, similia similibus formula), imply that the original aim of curses was to bind but not to destroy the victim. Both the spoken formula of the curse and the attendant gesture (distortion of lead or wax etc.) developed simultaneously; the fact that the earliest defixiones consist solely of lists of names suggests that a verb of binding was uttered aloud during the ritual; the later development of complex written formulae reflects a desire to inscribe more and more of the spoken charm on the tablet. In general, defixiones were deployed in a variety of contexts: commercial curses (25 examples), curses against atheletes and public performers ( 26 examples, usually imp.), amatory curses (38, 'separation' and 'aphrodisiac' curses), and judicial curses (67, class.-Hell.). However, a common feature, especially of the early defixiones, can be seen in the fact that they concern 'agonistic', competitive relationships. F. also comments on the use of retrograde writing, lead tablets, wax, and 'voodoo dolls', as well as on public rituals used to protect entire communities (p. 7-9). [AC]

70) D. FEISSEL, Nouvelles inscriptions de Cilicie et d'Antiocbène. Rapport préliminaire sur une mission (juin 1988), in De Anatolia Antiqua, 1 (1991), p. 51-54 [BE 1992, 535]: Brief presentation of unpublished inscriptions collected by F. in Kilikia and Antiochene. Seleukeia on the Kalykadnos: Dedications to emperors. Mersin: A dedication to Dionysos Kallikarpos, whose cult was popular in Kilikia. Antiocbeia of Pyramos: An honorific decree which should be set up in the sanctuary of Athena Polias. Aigeat: Four new examples of round altars bearing double dedications, to deities and members of the imperial family: a) Divus Caesar and Augustus (A), Julia Domna and other Augustae (B), b) Demeter Karpotrophos, Hadrian, and Isis (A), Severus Alexander and Augustae (B), c) unknown deities (A), Gallus and Volusianus (B), d) Dionysos Kallikarpos and Demeter Karpotrophos (A), an unknown emperor (B). Anazarbos: The theophoric name Sandogenes ( $<$ Sandan) persisted into the Christian era (AD 536). Flaviopolis: An attestation of the rare theophoric name Perasiodoros ( $<$ Artemis Perasia); an altar dedicated to Zeus Soter and the Olympian gods by a priest of Augustus. [AC]

71) G. FORREST, in $S E G, 40$ (1990) [1993], p. $227 \mathrm{n}^{\circ} 723$ : F. restores $E B G R$ 1989, $100 \mathrm{n}^{\circ} 5$ (SEG 39, 886; Chios, 1st c. BC) as a dedication of gymnasiarchs (not victors of athletic contests) to Hermes, Herakles, and the Demos. [AC]

72) B. Forsén, Gliederweibungen aus Piraeus, in $Z P E, 87$ (1991), p. 173-175 [BE 1992, 108. 247]: Ed. pr. of a dedicatory inscription on a marble slab with relief representation of male genitals (Asklepieion at Piraeus?, 2nd/3rd c.). The expression $\theta \varepsilon p \alpha \pi \varepsilon v \theta \varepsilon i \xi$ 
shows that the dedication was made after a healing. The depiction of genitals in relief on an inscribed stele is unique. [To the other examples given by F, add SEG 35, 1174 (Philadelphia, imp.)]. [ES]

73) B. ForSÉn - E. SIRONEn, Parische Gliederweibungen, in ZPE, 87 (1991), p. 176-180 [BE 1992, 110]: Collection and discussion of all known 'anatomical votives' from Paros; most of them bear dedicatory inscriptions, addressed to Asklepios (3 cases), Eileithyia ( 2 cases), and the Nymphs (1 case). [ES]

74) J.M. Fossey, Epigraphica Boetica I. Studies in the Boiotian Inscriptions, Amsterdam, 1991: F.'s book collects articles published in various periodicals (often with additions and corrections) and several new papers: a) Ed. pr. of a dedicatory inscription (p. 91-96, Kopai, ea. 2nd c. BC). Kopal dedicated the statue of a citizen to the gods; notice the rare name Theoterpidas. b) In an appendix to an article about the manumissions at Chaironeia (in $Z P E, 29,1978$, p. 123-137) F. discusses the local cult of Artemis Eileithyia (p. 152-155). He argues that the main cult of Chaironeia was that of Artemis, known primarily under the epithet of Eileithyia; her cult was associated later with that of Megale Meter, perhaps in the same sanctuary. The cult of Artemis persisted into Roman times, even though some of her functions were taken over by the increasingly popular Egyptian deities. [AC, ES]

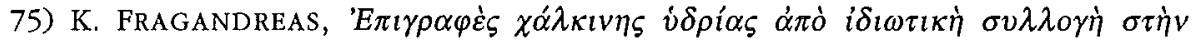

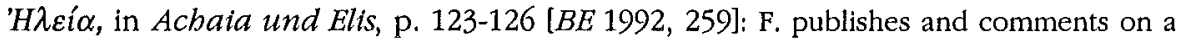
hydria from Elis, now in a private collection, bearing two dedicatory inscriptions, one addressed to Demeter (second half of the 5th century BC), the other to Artemis $\Pi \alpha \varphi \rho \alpha \kappa i \alpha$ (only attestation of this epithet, Hell,); the second dedication is followed by an indication of the weight. The origin of this hydria is probably Arkadia (Mantineia), as can be inferred from a comparison with another hydria also inscribed with two texts, an archaic dedication to Demeter and a Hell. indication of weight. F. offers three possible explanations for the fact that the new hydria had been dedicated first to Demeter and then to Artemis: a) The sanctuary was dedicated to both goddesses; b) an ancient cult of Demeter was replaced later by one of Artemis; c) Artemis became later the parhedros of Demeter. The weighing of the dedicated objects by officials may be related to the introduction of a new cult. [ES]

76) P.M. FRASER, Review of Supplementum Epigrapbicum Graecum XXXV, in $C R, 40$ (1990), p. 432-436 [BE 1993, 502]: 1) SEG 35, 638 (Malloia in Thessaly, ca. $200 \mathrm{BC}$, grave stele with representation of a herm): $F$, reads on the photograph of the original

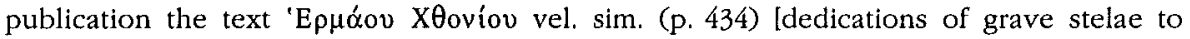
Hermes Chthonios are common in Thessaly: of. infra ${ }^{\text {os }}$ 248.249]. 2) SEG 35, 1174

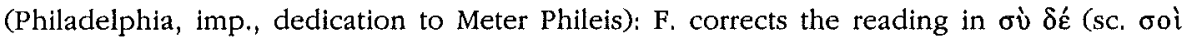

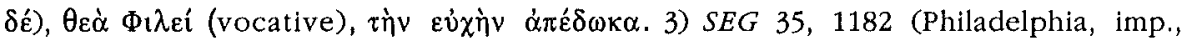
dedication to Meter Phileis): F. argues that the verb кo $\lambda{ }^{\prime} \zeta \varepsilon 1 v$ used in this dedication

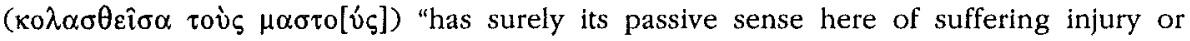
pain, and has nothing to do with punishment". [This inscription belongs to a larger group of texts, in which the verb always has the meaning 'to punish': TAM V 1, 261: غ́ко $\alpha \dot{\alpha} \sigma \theta \eta$

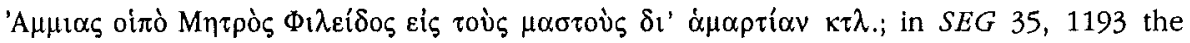
verb is followed by the verb $\dot{\varepsilon} \pi \zeta \eta \eta \varepsilon \hat{v}$, common in propitiatory inscriptions in connection

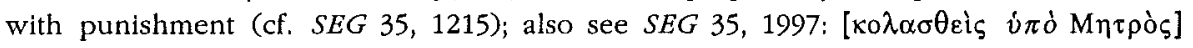


$\Phi_{1} \lambda \varepsilon^{i} \delta_{\delta} \sigma_{5}$. So G. PETZL is right in including these texts in his corpus of 'confession inscriptions' in $E A, 22$ (1994), nos $83-95]$. [AC]

77) S.S. FRERE - R.S.O. TOMLIN, The Roman Inscriptions of Britain. Volume II. Instrumentum Domesticum. Fascicule 2 (RIB 2412-2420), Oxford, 1991: Two glass

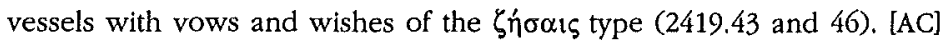

78) S.S. FRERE - R.S.O. TOMLIN, The Roman Inscriptions of Britain. Volume II. Instrumentum Domesticum. Fascicule 3 (RIB 2421-2441), Oxford, 1991: F.-T. republish a few Greek inscriptions on instrumentum domesticum found in Britain: A gold ring used as a love charm (По $\lambda \varepsilon \mu$ íov pí $\lambda \tau \rho o v$, Corbridge, 2422.12); a gold ring with the apotropaic formula $\varphi v \hat{\lambda} \alpha(\xi \alpha 1)$ (Corbridge, 2422.43); an amulet inscribed with the seven Greek vowels and a palindrome attested in invocations to Typhon (2423.1, representations of Isis, Ouroboros, Bes, a lioness, a uterine symbol, and a key with seven teeth); on the reverse OPSPIOY IAH $\Omega$ IA $\Omega$ IA $\Omega$ (representation of a scarabaeus); an amulet with the magical names IA $\Omega$ and $A \beta p \alpha \sigma \alpha \xi \Sigma \alpha \beta \alpha \dot{\omega} \theta$ (2423.15, representation of a cock-headed, snake-legged deity with a shield); an amulet with the name IA $\Omega$ (retrograde, 2423.16, representation of a cock-headed, snake-legged deity); an amulet bearing the seven Greek vowels (2423.17, representation of nude Harpokrates); a fragmentary gold amulet (2430.2, Wood Eaton) with the name Adonai and Greek letters, which have been repeated up to four times for magical effect; an intaglio with a representation of Sarapis flanked by two busts (the Dioskouroi ?) and the acclamation $\varepsilon(\hat{i} \varsigma) Z(\varepsilon \dot{v} \varsigma) \Sigma(\alpha \rho \rho \pi 1 \varsigma)$ (2423.12). Other gemstones, amulets, and cameos bear various

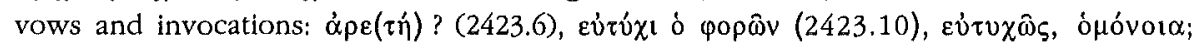
(2423.11, clasped hands; cf. 2423.19). [AC]

79) P. FRISCH, Der erste vollkommene Periodonike, in EA, 18 (1991), p. 71-73 [BE 1993, 602]: Discussion of the honorific inscription for the wrestler Maron [cf. infra $\mathrm{n}^{\circ}$

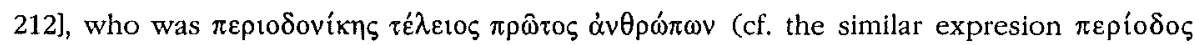

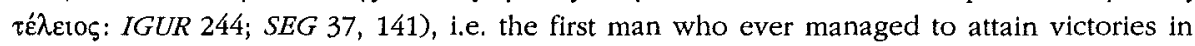
all the agons of the periodos (Olympia, Pythia, Isthmia, Nemea, Aktia, Capitolia, Sebasta). Only ca. 75 years (ca. AD 161-180) after the addition of Capitolia to the periodos (AD 86) did an athlete manage to fulfill this extremely difficult achievement. F, also gives a brief discussion of the terms periodos and periodonikes. [AC]

*80) E. Garrison, Attitudes Toward Suicide in Anclent Greece, in TAPhA, 121(1991), p. 1-34: Thorough study of the literary and epigraphic testimonia (LSCG 154) on suicide. G.'s aim is to disprove the theory of R. PARKER that an 'extra pollution' was assigned to suicide, so that punitive measures had to be taken against the corpse. The evidence is contradictory, but one overwhelming fact emerges: Social significance was attached to suicide, but very little odium or repulsion. Nothing unusual can be observed in the treatment of corpses of those who had commited suicide, beyond the pollution that results from death of any kind. [ES]

81) P.-L. GATIER, La culture grecque à Gerasa. Nouveaux documents, in Hellenismos, p. 325-337: Overview of the contribution of new epigraphic testimonia to our knowledge of Hellenism in Gerasa. G. mentions (p. 329) two unpublished honorific inscriptions for agonothetae (imp., one of them dedicated by the association of Dionysiac technites). [AC] 
82) W. GAUER, Die Bronzegefaße von Olympia. Teil I (Olympische Forschungen, 20), Berlin-New York, 1991 [BE 1992, 265]: Publication of bronze vases found in Olympia. Fragments of 9 cauldrons and 2 basins are inscribed (Le 12. 26. 36. 38. 39*. 53*. 294. 322*. 446*, P 50*. P 51*, 6th-5th c., new inscriptions are marked with an asterisk). The inscriptions name Zeus Olympios as addressee of the dedications; three vases were official dedications of communities (Spartans: Le 12; Eleans: Le 26; Anphidoloi: Le 294; Schoineis ?: Le 322*) [cf. infra $\mathrm{n}^{\circ}$ 221], two vases were dedications of individuals (an Athenian: Le 53*; Le 446*). [Cf. the remarks of L. DUBOIS, in $B E$ 1992, 265]. [AC]

83) M. GAWLIKOWSKI, L'bellénisme et les dieux de Palmyre, in Hellenismos, p. 245256: Overview of the cults at Palmyra (from the 1st c. BC onwards) with special emphasis on the elements of assimilation between Greek and Oriental gods. In certain cases (Nebo-Apollon, Nergal-Herakles), although the Greek iconography was adopted, the Semitic names persisted. The identification of some local gods with Greek deities was partly based on the similarity of their functions (Shams-Helios, Baalshamin-Zeus), partly on the similarity of their names (Arsu-Ares); however, many gods retained their indigenous name in a hellenized form (Iaribolos, Malachibelos, Aglibolos, Azizos, Atargatis), and only in rare cases a deeper hellenization may be observed (cf. the transformation of Allat to Dea Syria, Artemis, and finally Athena). Changes in sacral architecture, which acquires certain Greek elements, may reflect changes in rituals. Other interesting developments can be seen in the increasingly military character of the deities and their astrological interpretation. [AC]

84) D. GEAGAN, The Sarapion Monument and the Quest of Status in Roman Athens, in ZPE, 85 (1991), p. 145-165 [BE 1992, 242]: G. republishes (with many restorations) and discusses the epigraphic fragments of Sarapion's monument (SEG 28, 255), located in the Asklepieion of Athens. This unusual location for a choregic monument can be explained by the efforts of the priest Sarapion and his descendants to reshape the cult. Asklepios' cult was not exclusive, as was the Eleusinian cult, but had a more democratic character. Teachers, physicians, and philosophers belonged to the group of dedicators in the Asklepieion. [ES]

85) J. De LA GEnière, Pausanias et le sanctuaire de la Mère des dieux d'Akriai, in CRAI (1991), p. 257-265: G. comments on PAUSANIAS' account $(3,22,3)$ of the sanctuary of Meter Theon in Akriai (Lakonia). The poor remains of the settlement and the rarity of

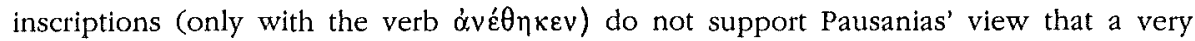
popular sanctuary of Kybele existed in Akriai. On the contrary, the remains rather point to a local deity, protectress of the cattle, whose sanctuary was situated between the arable land and the eschatia. [ES]

86) E. Gini-Tsophopoulou, in $A D, 43$ B1 (1988) [1993], p. 87: Presentation of a dedication (of the $\dot{\varepsilon} \mu v \eta \dot{\sigma} \sigma \eta$-type) to the Theoi Megaloi (Petra in Attika, 2nd c. AD); it probably comes from their sanctuary in the deme Kephale (cf. IG II ${ }^{2}$ 1323). [AC]

87) L. GODART, Dionysos e la Creta Micenea, in Atti della Academia Nazionale dei Lincei, 2 (1991), p. 7-9: G. discusses the new Linear B tablets from Chania found in 1990, which for the first time give firm evidence for the name of the god Dionysos. The fact that one document refers to the delivery of honey for sacrificial purposes to the sanctuary of Zeus, where Dionysos was also worshipped, shows that a link between the two deities existed already at that time. [ES] 
88) F. GRAF, Apollon Lykeios in Metapont, in Praktika, 2, p. 242-245: G. discusses the function of 15 dedications to Apollon Lykeios found in the 'sacred area' of Metapontion. The comparison with dedicatory inscriptions of the same types from other regions (a) name of a deity in genitive + name of the dedicant in genitive, b) name of the deity in genitive, c) name of the dedicant in nominative or genitive) shows that these inscriptions were set up in connection with a sacrifice, probably related to the cults of kinship groups and to their initiation rites. [ES]

*89) F. GRAF, Textes orphiques et rituel bacchique. À propos des lamelles de Pélinna, in Orpbisme, p. 87-102: G. offers a detailed analysis of the two Orphic leaves from Pelinna in Thessaly [cf. $E B G R$ 1987, 112; 1989, 42. 69. 71; 1990, 91. 107. 113. 149. $276]$ in view of literary parallels. The integral text according to $G$. (with his translation);

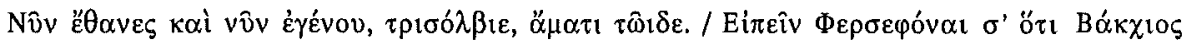

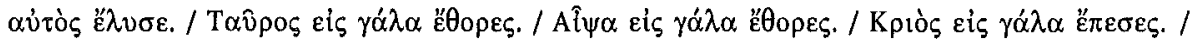

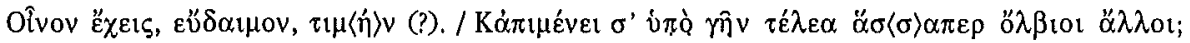
"en ce moment tu es mort, et en ce moment tu es devenu, ô trois fois bienheureux, ce jour-ci. Dis à Perséphone que Bacchios lui-même t'a libéré. Taureau, tu as sauté dans le lait. Vite, tu as sauté dans le lait. Bélier, tu es tombé dans le lait. Tu as reçu, bienheureux, le vin comme ton honneur (ton office ?)." Like the Oprhic texts of the group, B (according to G. ZUNTZ's classification, ) these verses contain instructions given by an initiator of Bacchic mysteries. The differences between the new text $(P)$ and those belonging to ZUNTZ's groups $A$ and $B$ demonstrate the existence of various streams within the Bacchic mysteries: Group A knows the rebirth and reveals perhaps the influence of Pythagorism, group B (Hipponion) gives a rich imagery of the path leading to the underworld, group $\mathrm{P}$ is addressed to Persephone and underlines the rôle of Dionysos in the 'liberation' ( $\lambda \dot{\sigma} \sigma \varsigma)$ of the mystes. The Thessalic texts provide some clues for the rite of initiation (ritual death, resurrection, perhaps after a period of food abstinence, beatification). [AC]

*90) F. Graf, Prayer in Magic and Religious Ritual, in Magika Hiera, p. 188-213: $G$. studies in what respect the magical prayers are different from prayers in non-magical contexts (basically in view of the magical papyri, but also making occasional use of inscriptions). The formal structure of prayers in magic (invocation, narrative part, wish) does not differ from non-magical prayers, except for the use of voces magicae. Differences can be seen basically in the ritual, which the magical prayer accompanies, i.e., the use of a materia magica, the holocaust, the fact that the sacrifice is not followed by a common meal. The rituals of the magician put him in opposition to the more usual ritual practices and isolate him from his fellow men. $[\mathrm{AC}]$

91) A.J. Graham, 'Adopted Teians': A Passage in the New Inscription of Public Imprecations from Teos, in JHS, 111 (1991), p. 176-178 [BE 1992, 397; cf. BE 1993, 454]: G. supports R. MERKELBACH's restorations of a passage in the Tean imprecations

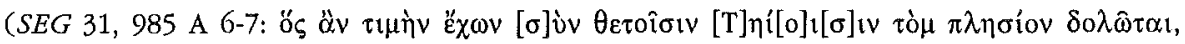

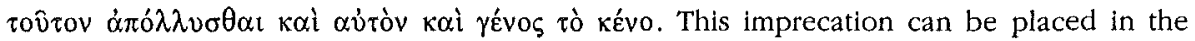
time of Teos' refoundation with the arrival of newcomers from Abdera ( $\theta \varepsilon \tau$ ei Trior = 'adopted Teians'). The imprecation could have been addressed against those magistrates who would try to 'enslave' the old 'Teians. [AC] 
92) F. GSCHNITZER, Bemerkungen zum Zusammenwirken von Magistraten und Priestern in der griechiscben Welt, in Ktéma, 14 (1989) [1993], p. 31-38: G. collects cases in which secular magistrates and priests conducted certain activities jointly (oaths, curses, prayers, sacrifices). In these cases the priests conducted the religious services under the responsibility or on behalf of the political authority (e.g. I.Cret III, iv 7; MEIGGS-LEWIS, GHI 30; SEG 31, 985; cf. also IG XI 4, 1296 A-B; LrVIUS 31, 44, 6; DIOD. 13, 69, 2; PLUT., Alcib. 33, 3). Although political magistrates sometimes conducted religious activities without the assistance of priests (e.g. SOLON fr. 65 Ruschenbusch; Syl $\beta$ 575; SCHWYZER 688; SEG 33, 679; LSAM 16), the opposite procedure is not common. G.'s study illustrates the subordination of the religious sphere to political authority. [AC]

93) C. HABICHT, Milesische Theoren in Atben, in Cbiron, 21 (1991), p. 325-329 [BE 1992, 416]: Remarks on the prosopography of thoeroi sent by Milet to Athens ( $I G \mathrm{II}^{2}$ 992); the architheoros may be identified with Euandrides, son of the stephanephoros (221 BC) Euandrides, whose ancestor Antenor had been honoured in Athens in $306 \mathrm{BC}$. Another member of the delegation, Hermophantos, was the son of Lichas, who had also been honoured by Athens for his political achievements; Hermophantos served as architheoros sometime later [see now W. GÜNTHER, Athenisches Bürgerrecht für Theoren aus Milet, in $E A, 19$ (1992), p. 135-143]. Thus the inscription should be dated in the first quarter of the 2nd c. (ca. 185-180 ?). H. suggests that Miletos and other Ionian cities still sent theoriai regularly to Athens, perhaps only on the occasion of the Great Panathenaia (according to the older restorations of $I G \mathrm{II}^{2} 992$ this occasion was the celebration of the Great Mysteries of Eleusis). [AC].

94) D. HARrIS, Gold and Silver on the Athenian Acropolis: Thucydides 2.13 .4 and the Inventory Lists, in Horos, 8/9 (1990/91) [1993], p. 75-82: Thukydides predicted the need for the Athenians to borrow from the treasury of Athena; his prediction was realized when the treasures were melted down for coinage in $407 / 6$. The treasury was immediately reimbursed through pious dedications. In the 4th $\mathrm{c}$. dedications were melted down in order to create new, grander votives. [AC]

95) M. Hatzopoulos, Un prêtre d'Amphipolis dans la grande liste des théarodoques de Delphes, in $B C H, 115$ (1991), p. 345-347 [BE 1992, 320]: H. identifies the eponymous priest of Asklepios in Amphipolis, Xenotimos Epikratous, mentioned in a new inscription from Amphipolis (cf. K. LAZARIDI, in PAAH 1985 [1990], p. 74), with [- - ]timos Epikratou mentioned in the Delphic list of thearodokoi. This list can now be dated more accurately (ca. 230-220 BC). [ES]

*96) G. HEDrEen, The Cult of Achilles in the Euxine, in Hesperia, 60 (1991), p. 313$330[B E$ 1992, 328; SEG 40, 610]: Achilles' whorship in the Black Sea was not confined to one place or to the immediate vicinity of his tomb, but was popular among the Greeks of

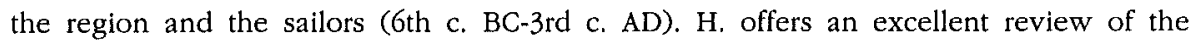
archaeological and epigraphic evidence of this cult. The archaic testimonia (6th c.) include graffiti basically on clay discs (perhaps pieces of board games), bearing depictions of snakes, human figures, boats, swords, and daggers, found in Olbia and its vicinity (Beikush, Berezan), and in Chersonnesos (Tauris). H. gives several parallels for the offering of similar disks to heroes and dead persons. The later epigraphic and archaeological evidence comes from various sites: Tendra (Achilleos drymos), perhaps the place where athletic agons were held, Achilleion near the entrance to the Maiotis, 
Leuke, and a site in the mouth of Borysthenis (a dedicatory altar). H. offers a persuasive explanation for the popularity of Achilles' cult in this area: Early epic poetry connected Achilles with Scythia, an area regarded as opposite to Ethiopia; as Sarpedon was carried by Eos to Ethiopia after he had been killed by Achilles, it was believed that Thetis carried the dead Achilles to the opposite region, i.e. Scythia. The Aethiopis, which narrated Sarpedon's death, must have been known to the Milesian colonists, since Arktion, one of the poets of the epic cycle, was a Milesian. [AC]

97) C.W. Hedrick, Jr., The Decrees of the Demotionidai, Atlanta, 1990 [BE 1991, 167; $S E G$ 40, 132]: Reedition, translation, and detailed commentary of the decrees of the Athenian phratry of the Demotionidai ( $I G \mathrm{II}^{2} 1237=L S C G$ 19), including a discussion (p. 25-30) of the first clause of the first decree, which defines the perquisites of the phratry priest from two sacrifices offered on the third day of the Apatouria, when children were presented to the phratry. The perquisites from the sacrifice meion, offered by the fathers of children born in the previous year, included a flank, a haunch, and one ear of the sacrificed animal (sheep ?), and 3 obols; the perquisites from the sacrifice koureion, offered by the fathers of boys who passed from childhood to adulthood, included a haunch, a flank, and one ear of the sacrificed animal (sheep or goat ?), a cake, a portion of wine, and 1 drachma. [AC]

98) C.W. HEDRICK, Jr., Phratry Sbrines of Attica and Atbens, in Hesperia, 60 (1991), p. 241-268: $\mathrm{H}$. challenges the traditional view that the phratries were in origin 'pure' kinship groups; he underlines the territorial/geographical character of Attic phratries through a study of the location of phratry shrines and their deme affiliations, using many literary, epigraphic, and papyrological sources. The location of the shrine or phratry estates is known for the following phratries: Achniadai, Gleontian phratry, Demotionidai (cult of Zeus Phratrios) [see supra $\mathrm{n}^{\circ}$ 97], Dyaleis, Elasidai (Apollon Patroos), Therrikleidai (heros Therrikles), Thymaitian phratry (Zeus Xenios, Herakles?) [cf, $E B G R$ 1988, 69], Medontidai, Titakidai, Thyrgonidai, Philieis, and 8 anonymous phratries (two of them with cults of Zeus and Athena Phratrios); for another 17 phratries the deme affiliation is known, while in the case of 5 phratries neither the location nor the deme is known. The collection of the material shows that more than 12 phratries existed in classical Athens, most of their shrines being in the countryside, probably in the vicinity of some population center. The 6-7 urban shrines, all of them located in the Agora, may be secondary, subsidiary sanctuaries, founded because of the gradual concentration of population in the city; the primary shrines of these phratries must have remained in the countryside. $\mathrm{H}$. also gives a very helpful summary of what is known about the religious activities of the phratries (p. 251-255, especially their participation in the festivals Thargelia, Anthesteria, Great Dionysia, Synoikia, and Apatouria) and the physical appearance of the phratry shrine, the $p$ p $\alpha$ piov (p. 255-259, club houses, altars, temples); the phratry shrine dedicated to Zeus Phratrios and Athena Phratrios in the deme of Skambonidai is presented in detail. $[\mathrm{AC}]$

99) H. HEINEN, Thoeris und beilige Fische. Eine neue griechische Inschrift fiur Ptolemaios X. Alexander I., in J. SEIBERT (ed.), Hellenistische Studien. Gedenkschrift filr H. Bengtson, München, 1991, p. 41-53 [BE 1992, 559; SEG 40, 1573]: Reedition of an inscription which records the dedication of a propylon to the Egyptian goddess Thoeris (usually represented as a standing hippopotamus), by Egyptian priests ( $\theta \varepsilon \alpha$ yoi) in honor of Ptolemaios X Alexandros I and his children (107- $88 \mathrm{BC}$ ) [=EBGR 1990, 22]. 
Underneath the inscription, two sacred fish (oxyrhynchos, lepidotos) are respresented in relief, both with crowns above them. Other inscriptions, papyri, and archaeological testimonia related to these sacred fish imply that the inscriptions probably come from the Arsinoitan nomos (Kerkosiris ?). [ES]

100) H. HEINEN, Zwet neue ptolemäische Inschriften aus Mittelägypten (Safaniya), in F. GOMA - R. MÜLLER-WOLLEMANN - W. SCHENKEL, Mittelägypten zwischen Samalût und dem Gabal Abû Sir, Wiesbaden, 1991, p. 251-267 [BE 1992, 570]: a) Ed. pr. of a dedication for Ptolemy VIII and Kleopatra III (p. 251-258, Safaniya). b) Ed. pr. of a list of 8 cult officials (p. 258-261, Safaniya, 2nd c. BC). 6 persons were officials of a cult association (synodos), i.e. the present priest, two former priests, a synarchon, and an

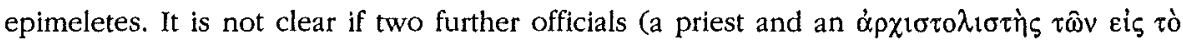

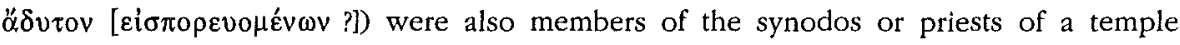
with which the synodos was associated. [J. BINGEN, in $B E 1992,570$ suggests that this synodos was a cult association of soldiers; perhaps the two inscriptions belong together, the second text containing the names of the dedicants of the first]. [AC]

101) P. HELLSTRÖM, The Architectural Layout of Hecatomnid Labraunda, in RA, 1991, p. 297-308 [BE 1993, 514]: $\mathrm{H}$. uses the epigraphic testimonia to reconstruct the history of the building programs in the sanctuary of Zeus at Labraunda, ca. $360-340 \mathrm{BC}$. He distinguishes three phases; the retaining wall for a terrace, which supported the road used for sacrificial processions, and a staircase belong to the Hekatomnid period. The obvious similarity which he notes between the plan of this sanctuary and the sanctuary at Delphi can be attributed to Delphic influence. [AC]

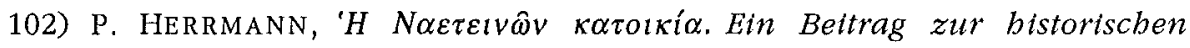
Landeskunde des südöstlichen Lydien, in Atalay Memorial, p. 77-85 [BE 1992, 428]: Ed. pr. of an honorific decree for Aur. Eilos by the community of Naeteinoi (vicinity of Blaundos, Lydia, AD 227). Eilos was high priest for the provincial imperial cult in Asia (an office also held by his son) and stephanephoros. $\mathrm{H}$. identifies him with the protos archon of the city Apollonos Hieron, known from the numismatic material. Apollonos Hieron should be located in the vicinity of Blaundos (east Lydia). [ES]

103) R. Herzog, Decreto del damos coo di Halasarna in onore del medico Onasandros, in PP, 46 (1991), p. 135-140 [BE 1992, 341]: Ed. pr. of an honorific decree of Halasarna on Kos for the doctor Onasandros (ca. 150-125), whose medical career and education of is described in detail. The decree was moved by three naopoioi. The honorific inscription was to be set up in the sanctuary of Apollon, near the honorific inscription for Onasandros' teacher Antipatros. [ES]

104) W. Huss, Die in ptolemaischer Zeit verfaßten Synodal-Dekrete der ägyptischen Priester, in ZPE, 88 (1991), p. 189-208 [BE 1992, 555]: H. collects and discusses thoroughly all known decrees passed by the synods of Egyptian priests, focusing on the relations between the indigenous religious centers and the Ptolemaic administration. He argues that there are no conclusive indications for either the Egyptian priesthood or the Ptolemaic administration having a superior position over the other. [ES]

105) A. INTZESSILOGLOU, in $A D, 42$ B1 (1987) [1992], p. 271 [BE 1993, 316]: I. reports the finding of a dedication to Moirai Patroai (Pherai, Hell.) [cf. the correction in $A D, 43 \mathrm{~B} 1$, 
1988, p. 259]. I. improves the reading of $I G$ IX 2, 397, which has been recovered; the text begins with the mention of a priest of Asklepios (Pherai). [B. HELLY, in BE 1993, 316 suggests that the scribe never finished the text]. [AC]

106) B. INTZESSILOGLOU, in $A D, 42$ B1 (1987) [1992], p. 271-272: Presentation of a dedication by a priest of Apollon (Kedros, nomos of Karditsa, Thessaly, 3rd c. BC). [AC]

107) B. IPLIKÇIOĞLU, Epigraphische Forschungen in Termessos und seinem Territorium I. (SB Akad. Wien, 575), Wien, 1991 [BE 1992, 511]: Ed. pr. of 24 inscriptions from Termessos (Pisidia), including dedications to Hadrian identified with Zeus Olympios (1, ca. AD 131), a text which mentions the festival $\Sigma \varepsilon \beta \alpha \sigma \tau \dot{\alpha} \Sigma$ o $\lambda \hat{v} \mu \varepsilon t \alpha$ in honour of the emperor and Zeus Solymeus or Heros Solymeus (both attested in Termessos, 3, ca. AD 180-212), a dedication to Artemis (6, ca. AD 120), and several epitaphs with funerary imprecations and prohibitions (8. 9. 13. 15-17. 19-21, after AD 212); in three cases the fine was to be paid to Zeus Solymeus. [ES]

108) B. IPLIKÇIOĞLU - A.V. ÇELGIN - G. ÇELGIN, Kuzey Likya'dan yeni yazitlar, in AST, IX, p. 183-192 [BE 1993, 532. 537]: Ed. pr. of inscriptions from Lykia (Komba, vicinity of Elmali), including an honorific decree for the high priest of Constantinus I and the Caesars, the grave inscription of a priest of Zeus Olympios (with the ethnic name

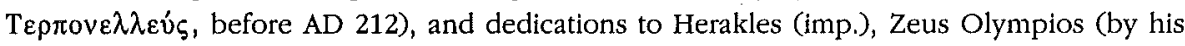
priest Aur. Tronkondas, imp.), the Dioskouroi (in fulfillment of a vow, imp.), and a group

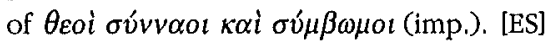

109) S. ISAGER, Kings and Gods in the Seleucid Empire. A Question of Landed Property in Asia Minor, in Seleucid Kingdom, p. 79-90: I. reexamines the problem of the 'temple states', recently discussed by L. BOFFO, I re ellenistici e $i$ centri religiosi dell'Asia Minore, Firenze, 1985, using the literary sources (Ps.-ARISTOTLE, Oeconomicus, STRABO) and the inscriptions; he basically focuses on the sanctuary of Ma at Komana and the dispute between the priest of Zeus Labraundos and the city of Mylasa. The latter dispute, about the sacred land, should be seen as a conflict between a traditional priestly rule and the rule of a city. In general, I. reaches the conclusion that the differences between 'temple states' and other monarchies were not pronounced. This does not mean that 'temple states' did not exist or continued to exist in the Hellenistic Period, but rather it is due to the minimal informations about them. [ES]

110) T. IVANOV, Neuentdecktes Heiligtum des thrakischen Reitergottes bei Sandanski (Sildwestbulgarien), in Praktika, 2, p. 286-289 [BE 1992, 325]: I. presents briefly a newly excavated sanctuary of the Thracian rider god $\Sigma \alpha \lambda \eta v$ ós, where a number of marble altars and inscribed reliefs were found. The inscriptions date between AD 219 and 243; the dedicants bear Greek and Roman names. The name of the deity probably derives from the unattested place name Sale. Clues to the nature of Salenos are provided by the thermal baths located in the vicinity of his sanctuary. [ES]

*111) A. JACQUemin, Remarques sur le budget sacrificiel d'une cité: Délos indépendante, in Espace sacrificiel, p. 93-98: On the basis of the accounts of the hieropoioi, J. studies the various expenses related to sacrifices in Hell. Delos (construction, repair, and decoration of altars, fuel, purchase of animals), the prices of sacrificial animals, and the various funds which covered these expenses. [AC] 
112) J. JARRY, Preliminary Report. Ninth Season of the Excavations at the Site of Akoris, Egypt, 1989, Kyoto, 1990 [BE 1993, 663; SEG 40, 1551 bis]: Ed. pr. (p. 26) of an inscription recording the flood of the Nile in the area of the sanctuary of Souchos,

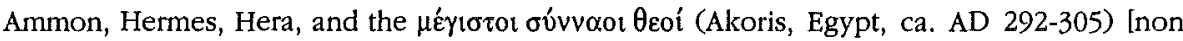
vidimus; for similar texts cf. $E B G R$ 1988, 13]. [AC]

113) A. JOHNSTON, Eulimene or not Eulimene, in MEFRA, 103 (1991), p. 177-182 [BE 1993, 109]: J. treats in detall two texts inscribed on the lid of a lead pyxis (GIBM 947; $A A, 1910, \mathrm{p} .508$ ). Both texts are written by the same hand in Ionic dialect and alphabet ( 6 th c. BC). The first text names the dedicant, Kratylos from Aegina, and the addressee of his dedication, the Nereid Eulimene, whose legend originates in Kydonia (West Crete). The second inscription contains a name in the genitive (Smikros from Aegina) and the

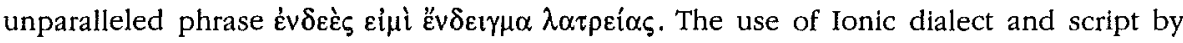
Aeginetan dedicants, the deity, and the unparalleled dedicatory inscription make J. suspect a modern forgery. [ES]

114) A. JOHNSTON, in SEG, 40 (1990) [1993], p. $496 \mathrm{n}^{\circ} 1604$ : J. presents an inscription, whose photograph was published in Sotbeby's Catalogue London, Antiquities (13-14 February 1990), p. $241 \mathrm{n}^{\circ} 444$ (unknown provenance, imp.). In the text a priest records

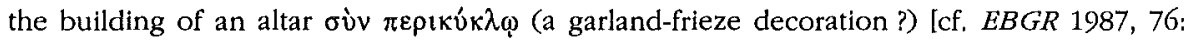

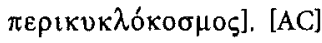

*115) S.I. Johnston, Crossroads, in ZPE, 88 (1991), p. 217-224: J. discusses the variety of rituals or superstitions related to crossroads and the respective rôle of Hekate. His starting point is the definition of the crossroads as "limital points or transitional gaps between defined, bounded areas, that is, between roads or between the areas of land that roads define." Accordingly, he distinguishes between protective and exploitive rituals. The first category is represented by rituals performed for Hekate (and Hermes), e.g. the bringing of supper or the cleaning and crowning of their statues on the night of the new moon. The second category of rituals comprises those exploiting the notion of dissociation related to the liminality of crossroads, e.g. leaving the polluted remains of household purification rituals $(\dot{o} \xi v \theta \dot{v} \mu t \alpha)$ on crossroads or performing magical rituals (with use of wax figures). Restless ghosts were also thought to be found at crossroads. The misunderstanding of these two different categories led writers already in antiquity to the assumption that Hekate was by nature a goddess of uncanny things. [ES]

116) C.P. JONES, Heracles at Smyma, in AJN, 2 (1990), p. 65-76: J. studies Herakles' portrayal on the coins of Smyrna (1st-3rd c. AD) in view of contemporary epigraphic evidence and a speech of Aelius Aristides. The goddess who crowns Herakles on coins struck under Trajan can be identified with Aphrodite Stratonikis. Herakles Prophylax or Hoplophylax was related to the office of the 'general in charge of the arms', who was responsible for the grain supply in Roman Smyrna. Aelius Aristides' speech 'To Herakles' (AD 166) was probably given in Smyrna. J. suggests that a shrine of Herakles existed in the strategeion of Smyrna, located in the same building as or near the arsenal and the granary. Aristides refers to the 'balls of Herakles', with which the hero had been seen playing. These balls may have been betyls or fetishes believed to guard the generals' building by themselves. [AC] 
117) D.R. JORDAN, A Mellichios Stone from Selinous, in $Z P E, 86$ (1991), p. 279-282 [SEG 40, 806]: J. discusses a dedication to Zeus Meilichios from Selinous [EBGR 1989, 6 $\mathrm{n}^{\circ} 50 ; E B G R 1989,29 \mathrm{n}^{\circ} 50$ ], which has been thought to reflect an association between Zeus Meilichios and the Eumenides. According to J.'s reading and translation ("I am (the stone) of Zeus Meilichios of Pyrrhias, Eumenidotos, Pediarchos") there is no connection between Meilichios and the Eumenides, although the connection between the individuals and Meilichios still remains obscure. [ES]

118) D.R. JORDAN, A New Reading of a Phylactery from Beirut, in ZPE, 88 (1991), p. 61-69 [BE 1992, 641]: Reedition (with some new readings and commentary) of a phylactery found rolled up inside a small bronze tube in a grave at Beirut (4th c. AD or later) with a long Greek inscription, in which a series of angels are invoked to protect Alexandra "from every demon and every compulsion of demons and from demonic (forces?) and magical drugs and binding spells... and dizzinesses and from every suffering and every madness". [ES]

119) A. Kalogeropoulou, 'A 2, p. 298-304: K. presents the epigraphic material found in the sanctuary of Pankrates in Athens (nine honorific decrees, a fragmentary catalogue with names of orgeones, dedicatory inscriptions on reliefs, a fragmentary inscription dating to the 5th $\mathrm{c}$. $\mathrm{BC}$ ). The

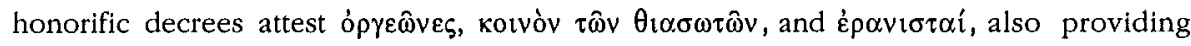
some details about their organisation. K. presents the text of one of these inscriptions $(300 / 299 \mathrm{BC})$ : It records a dedication to Pankrates by a group of eranistai $(\tau \alpha \mu i \alpha \varsigma$, $\dot{\varepsilon} \pi \mu \varepsilon \lambda \eta \tau \alpha$ í, $\gamma \rho \alpha \mu \mu \alpha \tau \varepsilon \dot{\xi})$ ); with the exception of two persons, the eranistai were not Athenian citizens. [ES]

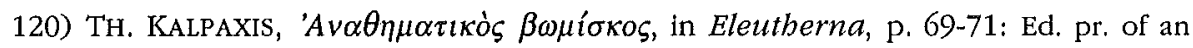
altar dedicated probably by a slave for his kyrios (Eleutherna, 2nd-4th $\mathrm{c} . \mathrm{AD}$ ). [AC]

*121) G. KAMINSKI, Thesauros. Untersuchungen zum antiken Opferstock, in JdI, 1991 [1992], p. 63-181 [BE 1993, 56]: This dissertation from the University of Marburg offers a thorough study of the archaeological and epigraphic evidence for the existence, name, typology, decoration, location, and cultic function of $\theta \eta \sigma \alpha v \rho o$, i.e. receptacles for the direct donations of worshippers ( $\pi \dot{\varepsilon} \lambda \alpha v o t, \dot{\alpha} \pi \alpha \rho \chi \alpha \hat{i})$, usually in the form of coins. These receptacles should be distinguished from pits and deposits found in various sanctuaries. Their basic features are stable fastening on walls or pavements, covers, and mechanisms for their locking and occasional opening. Such receptacles are found in sanctuaries of a great variety of deities ffor two new examples, in sanctuaries of Aphrodite Ourania and Asklepios, see infra $\mathrm{n}^{\text {os }} 244.249$ ], although they seem more common in sanctuaries of healing, oracle, water, and Egyptian deities. The pit ('Grube B') in the Asklepieion of Kos cannot be identified with the Onoavpós mentioned in LSS 155; K. corrects the

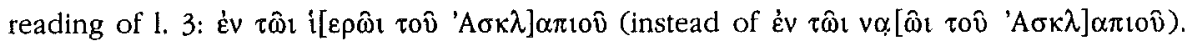
However, in certain cases (Asklepieia at Lebena and Epidauros, archive of Lokroi Epizephyrioi) the word $\theta$ nowupós was also used for pits. [AC]

122) C. KANTZIA, in $A D, 43 \mathrm{~B} 2$ (1988) [1993], p. 639: K. reports the finding of an altar of Zeus Kataibates in Kos (imp.). This is the first attestation for his cult in the city of Kos, but it was already known from Halasarna [EBGR 1990, 154]. [AC] 
123) G. KARAMITROU-MENTESIDI, in $A D, 42$ B2 (1987) [1992], p. 422: An Attic skyphos inscribed with the name of (and dedicated to) Themis was found in Aiane (Macedonia, I. 5th c. BC). [AC]

124) H. KARAPA-MOLISANI, One more dedication to the Emperor Hadrian at Athens, in Praktika, 2, p. 308-311: Ed. pr. of a dedicatory inscription for Hadrian by the city of Philadelphia in Lydia. The connection between the emperor and a 'Neos Dionysos' mentioned in the text, is not clear due to the fragmentary status of the inscription. [ES]

125) R, KASSEL, Korrekturen zu Epigraphica Anatolica 17 (1991), in EA 18 (1991), p. 74: See infra $\mathrm{n}^{\circ} 212$. [AC]

126) D. KNOEPFler, L. Mummius Achaicus et les cités du golfe eubolque: à propos d'une nouvelle inscription d'Éretrie, in $M H, 18$ (1991), p. 252-280 [BE 1992, 355]: Based on an inscription from Eretria (SEG 26, 1034-1035), which refers to two victors in

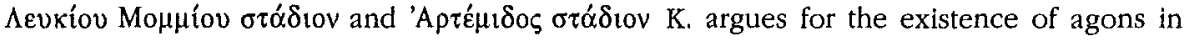
honor of the deified proconsul L. Mummius, which probably took place in the Artemision at Amarynthos. Mummius' deification leads $\mathrm{K}$. to a new approach of the history of the Euboan confederation in the 2nd c. BC; around 146 BC Eretria, opposing Chalkis, was in friendly terms with the Romans. [ES]

127) R. KoTANSKY, A Magic Gem Inscribed in Greek and Artificial Pboentcian, in $Z P E, 85$ (1991), p. 237-238 [BE 1992, 128]: Ed. pr. of an inscribed gem (Lebanon or Syria, 2nd-4th c.). The first five lines are written in an artificial Semitic script not giving any sense; the following three lines, written in Greek, contain a invocation against demons:

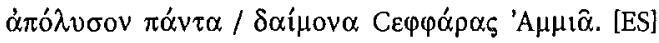

128) R. KOTANSKY, Magic in the Court of the Governor of Arabia, in ZPE, 88 (1991), p. 41-60 [BE 1992, 643]: Ed. pr. of a golden leaf (Bostra?, 4th c. AD) preserving 45 lines of Greek text and magical signs; it is charm meant to secure for Proclus a successful outcome in a trial before the dux Bostrorum Arabiae - the military governor of the province [cf, the remarks of D. FEISSEL, in BE 1992, 643 on the prosopography]. [ES]

129) R. KOTANSKY, Incantations and Prayers for Salvation on Inscribed Greek Amulets, in Magika Hiera, p. 107-137: K. offers an excellent overview of the various forms and aims of inscribed amulets (with extensive use of the inscriptions, the literary tradition, and the magical papyri). The application of amulets in early Greece was often accompanied by spoken prayers or incantations. Inscribed amulets are attested at the latest from the 4th c. BC onwards; however, the manufacture of amulets, often inscribed with incantations, flourished in late Hell, and in imperial times. $\mathrm{K}$. suggests that at least three of the 'Orphic' lamellae, which had once been rolled up or folded, could have been used as personal amulets; perhaps the use of the gold and silver phylacteries was patterned after these 'Orphic' lamellae. Other antecedants may have been the prophylactic inscriptions of Punic-Phoenician origin found in graves in Carthage and Sardinia 7 th-5th c.). The inscriptions are metrical incantations ( $\dot{\varepsilon} \pi \omega \delta \hat{i}$ ), apparent 'nonsense' words (voces magicae, long strings of magical logoi, series of vowels) which, however, may be regarded as incantations in the broadest sense of the word, and 'prayer formulae' that aim at a more general kind of protection. The amulets of the imperial period are basically concerned with health, mentioning a great variety of diseases. $[\mathrm{AC}]$ 
130) $\mathrm{CH}$. Koukouli-ChrysanthaKI, in $A D, 42 \mathrm{~B} 2$ (1987) [1992], p. 442: A dedication to Horos, Apollon, and Harpokrates by the priest of Isis and Sarapis (Philippoi, 3rd c. AD, originally published in $B C H, 53,1929$, p. 77-79) and lost during the war has been recovered in Kavala. $[\mathrm{AC}]$

131) CH. KoukOULI-CHRYSANTHAKI, in $A D, 43$ B2 (1988) [1993], p. 429: A dedicatory inscription believed lost $[A E$ 1936, p. 33-34], has been recovered. It reports the

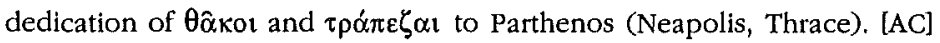

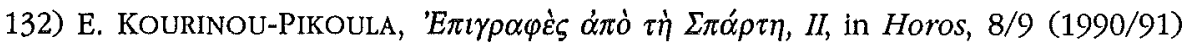
[1993], p. 93-98: Ed. pr. of inscriptions from Sparta: A dedication to Zeus Eleutherios Antoninos Soter, i.e. emperor Antoninus Pius (2, cf. $I G$ V 1, 440-444), the boundary stone of a sanctuary ( $3,1 \mathrm{st} \mathrm{c}$. AD), and the dedication of a boy-victor in the agon of

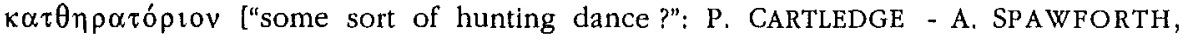
Hellenistic and Roman Sparta, London-New York, 1989, p. 205] performed in honour of

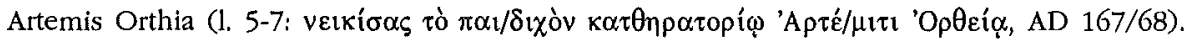
[AC]

*133) R.S. Kraemer, Maenads, Martyrs, Matrons, Monastics. A Sourcebook on Women's Religion in the Greco-Roman World, Philadelphia, 1988 [BE 1993, 416]: This collection of sources in translation (no commentaries) illustrates various aspects of women's religious life (rituals, observances, festivals, offices, conversion, religious ideas, goddesses); a sort introduction preceeds each chapter. The selected epigraphic sources include a few leges sacrae (LSS $15=4$, rituals for brides and pregnant women in the worship of Artemis; $\operatorname{LSAM} 48=7$, regulations in a Dionysiac thiasos), a dedication to Artemis Brauronia (5), a text narrating the establishment of Dionysiac rites in Magnesia on the Maeander (I.Magnesia $215=9$ ), texts referring to priestesses $(8.78 .80-82$ ), grave inscriptions with prohibitions or imprecations against the violation of the tombs (55. 57), the Isis aretalogy of Kyme (122), and many inscriptions related to the religious life of Jewish women. [The selection of Greek epigraphic sources (as compared to the numerous Jewish inscriptions) is rather limited, dispite the fact that translations of inscriptions are not as easily accessible as translated literary sources. The selection could have also included healing miracles, 'confession inscriptions', defixiones, or texts concerning the participation of women in festivals (e.g. the mysteries of Andania or the Eisiteria in Magnesia on the Maeander)]. [AC]

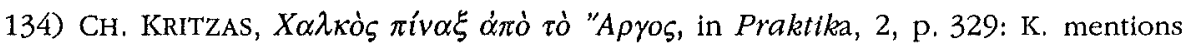
three inscriptions engraved on bronze sheets (Argos). One of them (ca. 460-450) mentions an account of 63, 710 drachmai, handed over to 12 phratries (of the tribe of the Hyrnathioi ?) by the hitherto unattested financial magistrates $\delta v o$ o $\delta \kappa \alpha$, revenues from the selling of skins to be used for the pentaeteris, and money given to the previously

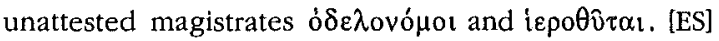

135) R. KRUMREICH, $Z u$ den goldenen Dreifüssen der Deinomeniden in Delphi, in JdI, 106 (1991) [1992], p. 37-62: The view that Gelon dedicated a golden tripod in Delphi after his victory at Himera in competition with the analogous dedication of the Greeks after their victory at Plataiai cannot be supported by the epigraphic and archaeological evidence. The dedications of Gelon and Hieron in Delphi aimed at presenting the two tyrants as benefactors of the sanctuary. [AC] 
136) E. KUNZE, Beinschienen (Olympische Forscbungen, 21), Berlin-New York, 1991 [BE 1992, 133]: Publication of bronze splints found in Olympia. The 14 dedicatory inscriptions mentioning Zeus Olympios (1-8: 6th c. BC; 9-14: 5th c. BC) are presented in an appendix (p. 125-130, $\mathrm{n}^{\text {os }} 1,2$, and 12 were unpublished, $\mathrm{n}^{\circ} 7$ with new readings). Several pieces were dedicated by cities after a military victory (cf. $\mathrm{n}^{\circ} 5$ : $\dot{\alpha} \kappa \rho 0 \theta i v 1 \alpha$, 0

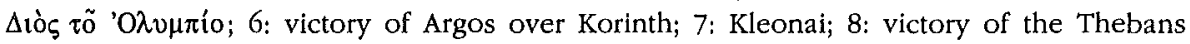
over the Hyetians; 9: Sikyon, after the battle of Halieis; 10: Sikyon; 11: victory of Zankle over Rhegion; $12^{*}$ : victory of Rhegion over Gela; 13 : victory of Rhegion over Lokroi; 14: victory of Messene over Lokroi). K. also presents 4 inscribed splints found in other places (15: dedication to Athena, Lykaion, arch.; 16-17: Dodona; 18: South Russial. [AC]

*137) Y, LAFOND, Artémis en Acbaie, in REG, 104 (1991), p. 410-433: Using epigraphic, literary and archaeological sources, $\mathbf{L}$. offers an analysis on the local cults of Artemis in Achaia and the various functions of the goddess (deity of purity, protectress of women, deity of civic life, goddess of war). [ES]

138) G.V. LALONDE, Horoi, in Agora, XIX, p. 3-51 [BE 1992, 8]: Corpus of all the boundary stones found in the Athenian Agora (131 texts). 25 texts are boundary stones of

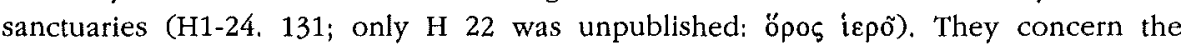
sanctuaries (or sacred estates) of Apollon Xanthos (H10), Apollon Patroios (H11), Athena Itonia (H1), Athena Polias (H21. 23. 24), Ge Kourotrophos (H18), Demeter (H4), Demeter Azesia (H16), Zeus Eleutherios (H7), Zeus Olympios (H13), Zeus (H15. 19), Herakles (H6), Herakles worshipped by the Thymaitian phratry (H131), the river-god Kephissos worshipped by the Gleontian phratry (H9), Meter (H14), the Anakes (i.e. the Dioskouroi, H5), the Nymphs (H3), the Tritopatreis (H20). The corpus also includes a horos of the road followed by the Pythaistai to Delphi (H34, 4th c. BC), and horoi of grave sites (H5372; H54-56 were unpublished). Several security horoi concern the economic activities of associations (eranistai: H84, 89, 94, 109). L. gives a very good introduction to the various groups of horoi. [AC]

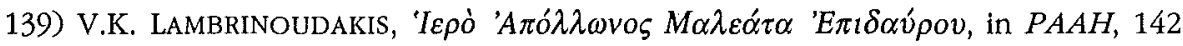
(1987) [1991], p. 52-65: L. reports (p. 60) the finding of two more altars dedicated to Apollon Deiradiotes and Artemis Hegemone respectively (sanctuary of Apollon Maleatas, Epidauros) [cf. $E B G R$ 1988, 126]. [AC]

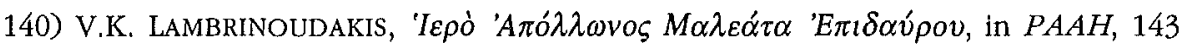
(1988) [1991], p. 21-29: Mention of an altar dedicated by a sacred official ( $\pi \nu \rho \varphi \circ p \eta \sigma \alpha \varsigma$

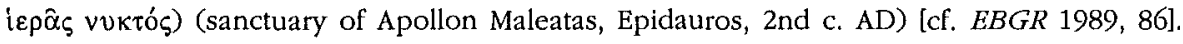
[AC]

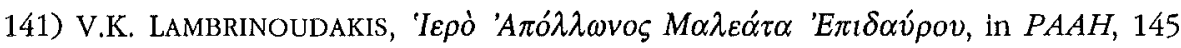
(1990) [1993], p. 45-49: Mention of an altar dedicated to the Muse Erato (4th c. BC, sanctuary of Apollon Maleatas, Epidauros) [cf. Ergon, 1990, p. 19]. [AC]

142) M.K. LANGdon, Poletai Records, in Agora, XIX, p. 55-143 [BE 1992, 8]: Corpus of the records of poletai found in the Athenian Agora, with a very good introduction to the subject, but with almost with no commentaries [see my review in Gnomon, 66 (1994), p. 696-697]. Only a few of the 54 texts are new (P43. 46. 51. PA4-7; the important inscription concerning the confiscated property of the persons involved in the profanation of the mysteries $\left(I G \mathrm{I}^{3} 421-430\right)$ is not included in the corpus. The poletai 
records concern the sale of confiscated property (notice the case of a person condemned for a sacrilege: P5 1. 13), the leasing of mines, and public contracts. They give important clues for the topography of Athens and Attica and for the location of numerous sanctuaries. Notice also that many mines were named after deities (cf. the index, p. 232234: Athenaikon, Apolloniakon, Artemisiakon, Archegeteion, Aphrodisiakon, Demetriakon, Dionysiakon, Dioskourikon, Heroikon, Hermaikon, Heraikon, Hephestiakon, Nymphaikon, Ploutoniakon, Poseidoniakon) [cf. the practice of giving names of deities to ships, gates etc.: e.g. $E B G R$ 1988, 3; 1990, 314]. [AC]

143) W.D. LEBEK, Korrekturen zu Epigrapbica Anatolica 17 (1991), in EA 18 (1991), p. 74 [BE 1993, 559]: See supra ${ }^{\circ}$ 48. [AC]

144) F, LEFÈvRE, Remarques sur le calendrier des réunions de l'Ampbictionie pyléodelphique, in $B C H, 115$ (1991), p. 579-594 [BE 1992, 276]: A re-examination of sources refutes the theory that the fixed months for the spring and autumn sessions of the Delphic amphictiony were Bysios and Boukatios respectively; the only months mentioned in the inscriptions are Heraios and Boathoos for the autumn session and Endyspoitropios for the spring session. L. argues that the members of the Amphictiony used a common calendar ( $\kappa \alpha \tau \dot{\alpha} \theta$ exóv) and that neither G. ROUX's distinction between two uses of the word $\pi v \lambda \alpha i \alpha$ (general assembly and accounting session) nor the view about a 'permanent delegation' formed by certain hieromnemones can be sustained anymore. [ES]

*145) B. Le Guen-Pollet, La vie religieuse dans le monde grec du Ve au IIIe siècle avant notre ère. Choix de documents épigraphiques traduits et commentés, Toulouse, 1991: P.'s book is a very useful and representative collection of 86 inscriptions related to religious matters. The inscriptions have been arranged thematically (sacrifice, hymnoi, religious taxes, cult personel, temple, i.e. boundaries, protection, regulations, and the rôle of religion in the life of a citizen). The lemmata include references to the state of preservation and the first edition, translation, and commentary. [ES]

146) B. LE GUEN-POLLET, Documents numismatiques et épigraphiques du musée de Tokat: Rapport de mission, jutllet 1988, in De Anatolia Antiqua, 1 (1991), p. 55-57 [BE 1992, 503]: L. mentions three unpublished dedications to emperors in the Museum of Tokat (Pontos), [AC]

*147) B. LE GUEN-POLLET, Espace sacrificiel et corps des bêtes immolées. Remarques sur le vocabulaire designant la part du prêtre dans la Grèce antique, de l'époque classique à l'époque impériale, in Espace sacrificiel, p. 13-23: From a very detailed study of the epigraphic material (basically leges sacrae) which attests for the parts of the sacrificial animal to be received by the priest, L. reaches the conclusion that the Greeks had neither very clear nor generally valid views about the anatomy of their sacrificial animals. The priest's perquisites from public sacrifices (meat, entrails) were much more substantial than in the case of sacrifices offered by individuals (the skin of the sacrificed animal). [AC]

148) C.S. LIGHTFOOT - J.F. HEALEY, A Roman Veteran on the Tigris, in EA, 17 (1991), p. 1-7 [BE 1992, 546]: Ed. pr, of an altar with a bilingual (Greek-Aramaic) dedication by a veteran of local origin (at Çattepe, at the confluence of the Tigris and Bohtan, early $3 \mathrm{rd} \mathrm{c}$. AD ?) [cf. the short report of L., in $A S T$, IX (1991), p. 431; BE 1993, 610]. The Greek text is a dedication to Zeus Olympios. The god is called $M \alpha \rho \eta \alpha \dot{\alpha} \lambda \lambda \eta$ (the reading is not 
certain) [cf. infra $\mathrm{n}^{\circ}$ 258], which is probably a reflection of the Aramaic epithet mrlh' ('lord of the gods', usually an epitheton of Sin, the moon-god of Harran). Approximately the same text stood in Aramaic in the opposite side of the altar; the addressee of the dedication in the Aramaic text is specified only with the divine title mrlh'. [AC]

*149) E. LIPPOLIS, Il santuario di Athana a Lindos, in ASAA, 66/67 (1988/89) [1993], p. 97-157: Presentation of the history of the sanctuary of Athena Polias in Lindos in view of the archaeological and epigraphic material. Recent reasearch shows that the sanctuary was destroyed by fire in the early 4th $\mathrm{c} . \mathrm{BC}$; its reorganisation and the building activity in the late 4 th $c$. probably followed the siege of Lindos by Demetrios Poliorketes (304 $\mathrm{BC})$. Further building activity can be dated in the 3rd and 1st c. BC, and under Tiberius. A study of the inscriptions shows the importance of the sanctuary for the local elite and implies the existence of a 'priestly cursus honorum' (p. 118-123): The members of the local aristocracy first held the lower priesthoods of Poseidon Hippios, Apollon Pythios, and Dionysos or the office of archierothytes, then the priesthood of Athena Lindia, before they could hold the Rhodian eponymous priesthood of Helios. [AC]

150) I. MALKIN, What Is an Aphidryma?, in ClAnt, 10 (1991), p. 78-96 [BE 1992, 237]: M. examines the various uses of the word $\alpha \dot{\alpha}$ í $\delta \rho \mu \alpha$, mainly in the literary sources. As to the epigraphic evidence, he agrees with L. ROBERT, in Hellenica, 13 (1965), p. 122 ss. inasmuch as he interprets aphidryma as a statue or a cult image, rejecting, however, the translation 'copy of a statue', which in his opinion derives from a priori assumptions. [ES]

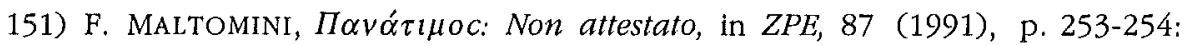
$M$. revises the inscription on a magical lead tablet from Fayoum (P.J. SIJPESTEIJN, in $Z P E$, 4,1969 , p. 187-191) and proposes, on philological and paleographical grounds, to read

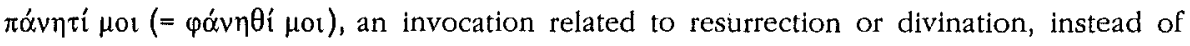
the unattested $\pi \alpha v \alpha \dot{\alpha} \tau \mu \circ \varsigma$ (1. 21). [ES]

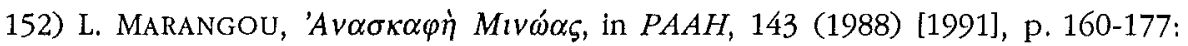
M. mentions (p. 174) an inscription found in the gymnasium of Minoa (Amorgos). IOn the

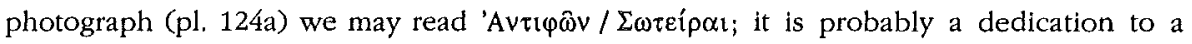
goddess with the epithet Soteira (Hell.)]. [AC]

*153) M. MARCOVICH, The Gold Leaf from Hipponion Revisited (SEG 26, 1139), in Ziva Antika, 40 (1990) [1992], p. 73-78 [BE 1993, 25; SEG 40, 824]: M. reedits the gold leaf from Hipponion [cf. $E B G R$ 1989, 109] ] with many conjectures, based on the combined text of the Orphic texts from Petelia and Thessaly [EBGR 1988, 155 and supra $\mathrm{n}^{\circ} 89$ ]. Some of the conjectures are daring, even given the corrupt state of the text; for a review

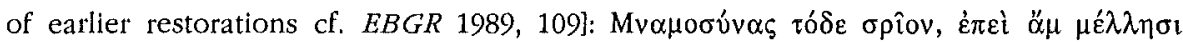

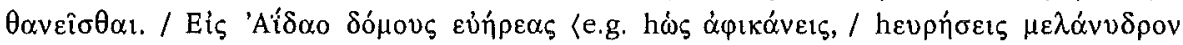

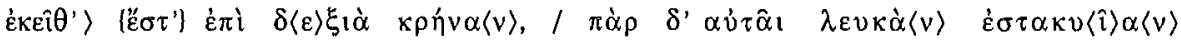

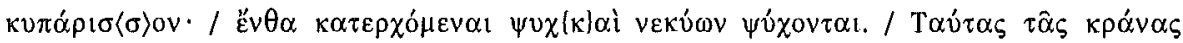

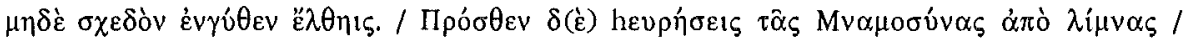

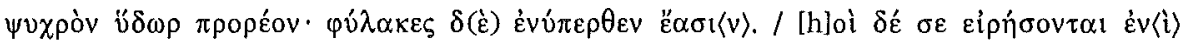

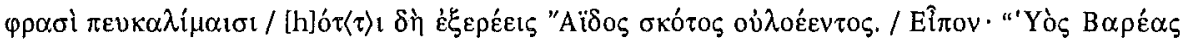

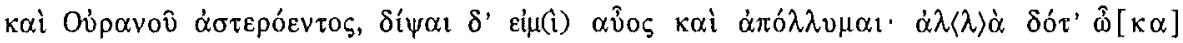

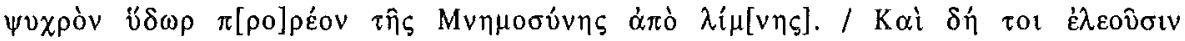

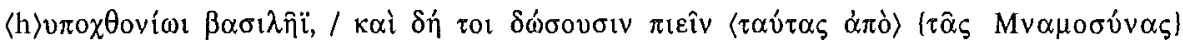

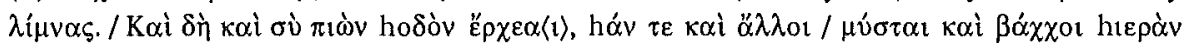


$\sigma \tau \varepsilon^{\prime}$ xovor $\kappa \lambda\langle\varepsilon\rangle \varepsilon$ ivoí. M.'s translation: "This is the leaf of Remembrance for the time when we shall die. <When you reach> the well fitted house of Hades, <you will find there> on the right hand a spring <with black water> and close to it a tall shining cypress. This is the place where the descending souls cool themselves. Take good care not to come close to this spring. Further on you will find a cold stream flowing out of the lake of Remembrance. And there are guardians standing by the stream. They will ask you with shrewd mind, what for are you searching through the darkness of the deadly Hades. Answer to them: 'I am a son of the Heavy (Earth) and the starry Sky. But I am drained diy with thirst and I am perishing. So give me quickly cold water flowing out of the lake of Remembrance'. And they will show mercy to you a king of the Netherworld, and will give you to drink from that lake. And after drinking you will tread the holy path on which walk also other renowned initiates and worshippers." In a short discussion of the text $M$. underlines the rôle of Mnemosyne, a sister of the initiates, since she was thought to be a daughter of Gaia and Ouranos. Mnemosyne assisted the initiates in remembering their initiation. [AC]

154) A. MARTIN, De quelques inscriptions des Syringes, in $C E, 66$ (1991), p. 356-360 [BE 1993, 671]: Remarks on the names and the origin of pilgrims and visitors of the "Syringes" at Thebes. [AC]

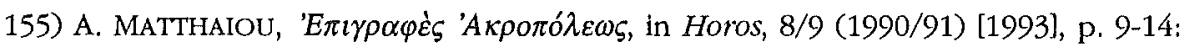
Ed. pr. of a dedication to Hermes (Athenian Akropolis, ca. 480-470). [AC]

156) A. MATt'thaiou, $\Psi \dot{\eta} \varphi t \sigma \mu \alpha N \alpha \xi i \omega v$, in Horos, 8/9 (1990/91) [1993], p. 113-117: Ed. pr. of a decree (late 4th c. BC) which was to be set up in a sanctury of Apollon in Naxos, probably that of Apollon Delios, known from literary sources. [AC]

157) R. MERKElBaCH, Weg mit Dir, Herakles, in die Feuerbölle!, in ZPE, 86 (1991),

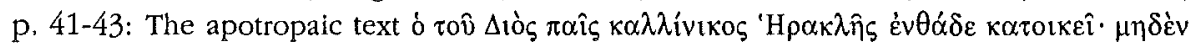

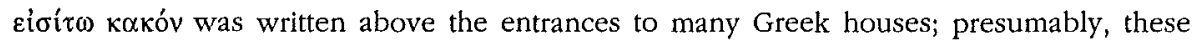
houses had a statue of Herakles "living" in them. [For the apotropaic function of Herakles cf. supra $\left.\mathrm{n}^{\circ} 116\right]$. In the process of Christianization, Herakles was banished and replaced by the equivalent Christian saints, as the vita of St. Phokas and some papyri inform us. [ES]

158) R. MERKELBACH, Ares und Apbrodite auf einer Gemme, in $Z P E$, 86 (1991), p. 44 [BE 1992, 40. 127]: The text inscribed on an amulet (IG XIV 2413, 10) is restored as

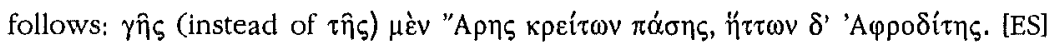

159) R. MERKELBACH, Epirotiscbe Hilfstruppen im Krieg der Römer gegen Aristonikos, in ZPE, 87 (1991), p. 132 [BE 1992, 33]: M. restores 1.12 of a dedicatory epigram for Herakles Soter ( $S E G 36,555$, Kassope, 1. 2nd c. BC), so as to fit the meter. The epigram was dedicated by Epirotian auxiliary troops from Buchetia on the occasion of the military campaign against Aristonikos. [ES]

160) R. Merkelbach, Ein Orakel des Apollon für Artemis von Koloe, in ZPE, 88 (1991), p. 70-72: M. comments on a metrical oracle of Apollon edited by D. KNIBBE, in Österreichisches Arcbäologisches Institut. Berichte und Materialien, Heft 1, Wien, 1991 [non vidimus; the text is also mentioned in $E B G R$ 1988, 92]. According to M. the oracle was given by Apollon of Didyma or Klaros to a city in the vicinity of Sardeis in a saliferous area. Apollon gave the order to fetch from Ephesos the goldplatted statue of Artemis. 
M. identifies the city in question with Koloe, where the famous sanctuary of Artemis Koloene was located. His interpretation finds further support in two Lydian inscriptions mentioning the cults of both the Ephesian Artemis and Artemis Koloene. M. also discusses the magical rituals (burning of wax figures, 1. 7-9); a parallel can be found in the 'oath of the colonists' of Kyrene (MEIGGS-LEWIS, GHI 5, 1. 44) [on this text cf. supra $\mathrm{n}^{\circ}$ 68]. [ES]

161) R. MERKELBACH, Korrekturen zu Epigrapbica Anatolica 17 (1991), in EA, 18 (1991), p. 74 [BE 1993, 534]: See infra n 211.

162) H. MEYer, Antinoos. Die archäologischen Denkmäler unter Einbeziebung des numismatischen und epigrapbiscben Materials sowie der literariscben Nacbrichten, München, 1991 [ $B E$ 1992, 112]: This exhaustive study on Hadrian's deified friend Antinoos focuses also on Antinoos' worship in the Roman Empire (esp. p. 164-173, 181212, 243-260) and the organization of his cult (sanctuaries, priests, agons, oracles, mysteries). According to the epigraphic and literary testimonia, Antinoos was identified with several other gods (Adonis, Belenus, Eros, Ganymedes, Hermes). $\mathrm{He}$ was worshipped as a fertility, healing, moon, and protecting deity with a variety of epithets (Argeiphontiadas, Choreios, Deus amabilis, Deus frugiferus, Ephebos, Epichorios Theos

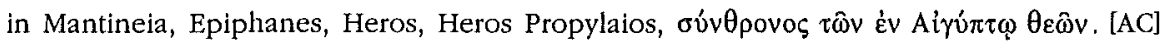

163) N.P. MILNER, Victors in the Meleagria and the Balbouran Elite, in AS, 41 (1991), p. 23-62 [BE 1993, 541]; M. presents a series of 20 inscriptions (10 of them unpublished) concerning the victors of the Antoninia Meleagria, a quadrennial agon (themis) founded at Balboura in ca. AD 158-161 [cf. EBGR 1989, 23]. The celebrations stretch from soon after AD 158 to at least the second quarter of the 3rd c. AD and were organised by the agonothetai for lifetime Thoantianos II and III, grandson and great-grandson of the founder Meleagros. The musical festival (skenikos kai thymelikos agon: 19; mousikos agon: p. 60) followed the model of the Demostheneia at Oinoanda [cf. $E B G R$ 1988, 193]. Only victor statues of the athletic part of the festival are preserved; they attest contests in wrestling, pankration, and foot-race (stadion) in two classes (boys and men). Since no victor comes from outside Balboura, it appears likely that the athletic section was a closed competition. The majority of the victors were members of the local élite. Among the inscriptions republished (with corrections) notice the honorific inscriptions for a local priest of Dionysos for lifetime (13) and a priest of the Lykian Koinon for the cult of Apollon Patroios Theos (14). M. also publishes an honorific inscription for an anonymous official, who had served as panegyriarches at the Meleagria and priest of the local imperial cult (together with his wife, 19, after AD 220), and for the agonothetes Thoantianos II, who also served as priest of the Lykian Koinon for the cult of Dea Roma, priest of Dionysos for lifetime at Balboura, and priest of the Muses in Attaleia (20, after $A D$ 212). (AC]

164) E. MiRANDA, Una gemma 'gnostica' dalle catacombe di S. Geanaro, in Rivista di Archeologia Cristiana, 67 (1991), p. 115-124 [BE 1993, 710]: Ed. pr. of a lapis lazuli gem found in a tomb of the 6th c. AD (Naples). It is inscribed with a 'gnostic' text almost identical with that on a gem published by D. WORTMANN, in Bonner Jabrbilcber, 175

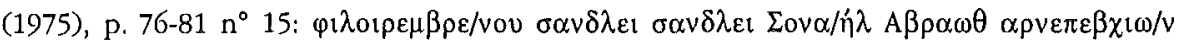

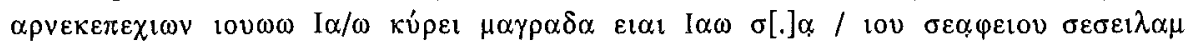

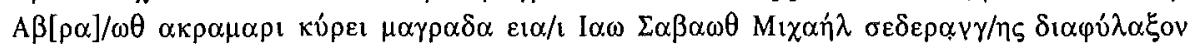




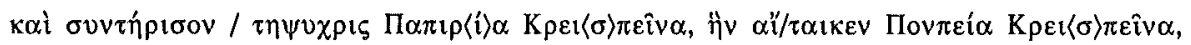

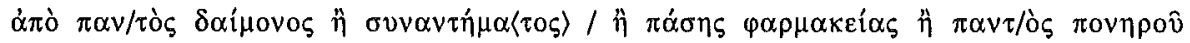

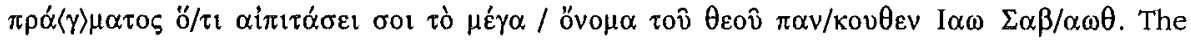
texts consists of names (the angels Sonael and Michael, Abraoth, Sabaoth, Pantkouthen, Iao etc.), magical words partly deriving from the Egyptian, Hebrew, and Greek languages, sequences of vowels (also on the backside of the gem), and a Greek text, according to which the gem should protect its owner Papiria Crispina, the daughter of Pompeia Crispina [the names imply an earlier date: cf. L. DUBOIS, in $B E 1993,710$ ], from daemons, unpleasant encounters, the use of poison or spells, and any other evil thing. Papiria may have been Christian, if $\tau \eta \psi v \chi \rho 1 \varsigma$ is an abbreviation of $\tau \grave{\eta}(v) \psi v(\chi \grave{\eta} v)$ $\chi p \iota \sigma(\tau \iota \alpha v \eta \dot{\eta})$. M. interprets the word $\lambda \alpha v \alpha \delta o v \lambda \kappa \imath \varsigma$ in the text published by WORTMANN as an abbreviation of anima dulcis. $\Sigma \alpha v \delta \lambda \varepsilon 1$ in 1.2 may be related to Persephone's sandal.

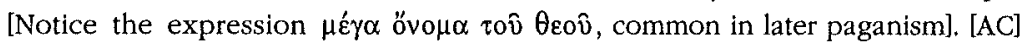

165) S. Mitchell, Ariassos 1990, in $A S$, 41 (1991), p. 159-172 [BE 1993, 587]: $M$. mentions two inscriptions of an emperor (Caracalla?) called theos and megas theos (Ariassos, early 3rd c. AD). [AC]

166) T.B. MrTFORD, Inscriptiones ponticae - Sebastopolis, in ZPE, 87 (1991), p. 181243 [ $B E$ 1992, 14. 620]: Ed. pr. of the following inscriptions from Sebastopolis: 1-2) Two dedications by beneficiarii consularis to Pylon Epekoos (1, 1st c. AD), a deity already known from Zara and Komana, and to Zeus Pylaios (2, 1st c. AD). The two deities were regarded as guardians of gates and protectors of public safety on the highways, with small shrines in the vicinity of the city gates at Sebastopolis and Komana. 3) A dedication to Asklepios Soter (imp). 4) A dedication to Theos Hypsistos (1. 2nd c, AD) lon the significance of the epithet $\mathrm{cf}$. infra $\mathrm{n}^{\text {os }}$ 181, 241]. [ES]

167) J.-P. MOREL, Le sanctuaire de Fondo Ruozzo à Teano (Campanie) et ses exvoto, in CRAI, 1991, p. 9-33: Reports on the excavations of a sanctuary of Demeter at Teano (Campania), revealing two distinct phases of activity (1. 6th-5th c. and 1. 4th-3rd c. $\mathrm{BC}$ ). The finds show that also the following deities were worshipped there: Aphrodite, Artemis, and Hera or Iuno Populania (attested epigraphically at Teano). M. attempts to define the nature of these cults. [ES]

168) J.-M. MORET, Circé tisseuse surles vases du Cabirion, in RA, 1991, p. 227-266; A loom appears at least on 4 vases representing the encounter of Odysseus and Kirke (Kabeirion at Thebes, 5th c. BC). M. relates this iconographic element to Orphic ideas. The parallels are basically literary texts of the later Neoplatonism, which attest the rôle of loom and weaving in the Orphic tradition. The persons represented on one of the Kabeirion vases may be identified with the help of inscriptions as Kabiros, Pratolaos ('the first man'), Pais, Krateia ('strength', 'power') and Mitos (a word meaning 'sperm' in the Orphic tradition); according to $M$. this scene illustrates the origin of humanity. $M$. also provides a helpful collection of testimonia on the rôle of weaving in rituals and in religious symbolism. [AC]

169) E. MOROTI, Miscellanea Graeco-Latina, in Gymnasium, 98 (1991), p. 177-180 [BE 1992, 532]: M. restores the second line of an oracle from Syedra (Kilikia, G.E. BEAN T.B. MITFORD, Joumeys in Rough Cilicia, 1962-1963, Wien, 1965, n²6; L. ROBERT, Documents de l'Asie Mineure méridionale, Paris, 1966, p. 91-100 $n^{\circ}$ 4) referring to pirates:

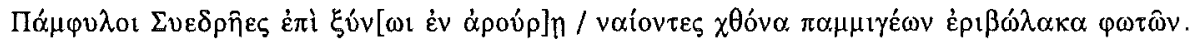


According to this restoration, the two verses contain Homeric reminiscences. [On the same text cf. supra ${ }^{\circ} 68$ ]. [AC]

170) I. NICOLAOU, Inscriptiones Cypriae Alphabeticae XXX, 1990, in RDAC, 1991, p. 195-202 [BE 1993, 612]: Presentation of new epigraphic finds from Cyprus; among them a dedication to Theos Hypsistos (Limassol, 2nd/3rd c.) and Zeus Labranios (Limassol, 3rd c. AD). [AC]

171) A. NIKA, in $A D, 43$ B2 (1988) [1993], p. 652: Presentation of a dedication to the gods by a koinon of soldiers (Rhodes, Hell.). [AC]

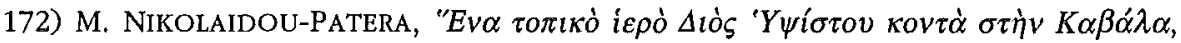
in Thrakike Epeterida, 7 (1987-1990), p. 213-221: Discussion of two dedications of the 1st $\mathrm{c} . \mathrm{BC}$ and the late $2 \mathrm{nd} \mathrm{c} . \mathrm{AD}$ respectively (the last one was unpublished) to Zeus Hypsistos; they were found $10 \mathrm{~km}$ east of Kavalla, probably in the area of a sanctuary dedicated to this deity [cf. N., in $A D, 42$ B2 (1987) [1992], p. 444-445 = BE 1993, 371; $S E G$ 40, 572]. [AC]

173) V. NINIOU-KINDELI, in $A D, 42$ B2 (1987) [1992], p. 568: A rural sanctuary was excavated at Tsiskiana (eparchy of Selino, West Crete). Among the finds were 436 statuettes of oxen and a Hell. dedicatory inscription, which provide a clue as to the identity of the shrine's dedicatee. [AC]

174) A. NTINA, in $A D, 42$ B1 (1987) [1992], p. 302: Presentation of a grave stone providing for a fine in case of any violation of the tomb (Nea Anchialos $=$ Phth. Thebes, imp.). [AC]

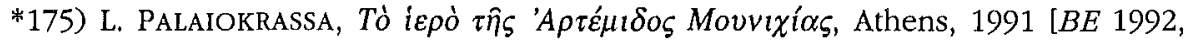
246]: P. collects the written sources about the sanctuary of Artemis Mounichia at Pireus and publishes a substantial part of the finds of the excavation conducted there in 1935 (sculpture, tablets, pottery, small objects, inscriptions). New texts are marked with an

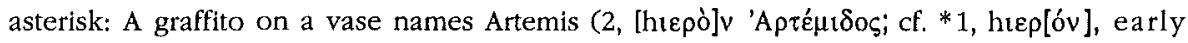

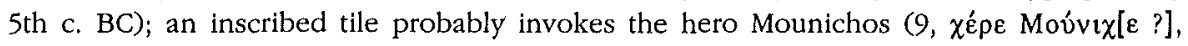
$1 \mathrm{st} / 2 \mathrm{nd}$ c.) [this object is not an altar, as believed by S. FOLLET, in $B E 1992,246$, who suggested that the inscription is an epitaph]. The fragmentary inscriptions on stone include dedications to Artemis (*3. 4. 7, 4th c. BC), ephebic inscriptions (5. *8, 4th c. BC), and an interesting inventory of the sanctuary $(6,4$ th c. BC); the items listed include dedications ( $\chi \lambda \imath \delta \omega v i \delta$ เov, i.e. a piece of jewlery) and cult implements $(\theta v \mu[1 \alpha \tau \dot{n} \rho t o v]$, $\chi \varepsilon \rho \vee[1 \beta \varepsilon i o v]$, ó $\beta \varepsilon[\lambda o ́ \varsigma$ ?], $\kappa \rho \varepsilon[\alpha ́ \alpha \rho \alpha$ ?]). P. discusses in detail the history of the sanctuary 7 th c. BC-2nd c. AD), the building activity ( 6 th- 4 th c. BC), the nature of Artemis Mounichia (goddess of fertility and birth, protector of youth, worshipped as Phosphoros and Hekate), her relation to other deities (Aphrodite, the Nymphs, Dionysos), the relation of this sanctuary to the Artemision at Brauron, and the institution of arkteia. [AC]

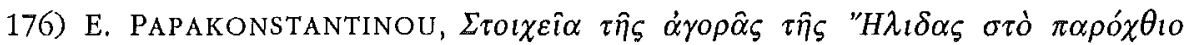

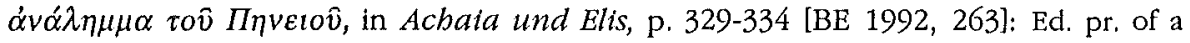

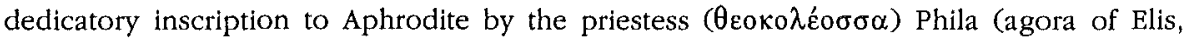
2nd c. BC). Aphrodites' sanctuary was described by PAUS. 6, 25, 1. Phila was probably the wife of the Eleian Olympic victor Anauchidas. [ES] 
177) L. PAPAKOSTA, in $A D$, $42 \mathrm{~B} 1$ (1987) [1992], p. 153: In a Hell, grave in Aigion, two golden leaves were found inscribed with the names of the deceased men (Dexilaos, Philon) and the dedignation $\mu$ vior $\alpha$ s. [AC]

178) A. PARIENTE, Chronique des fouilles en 1990, in BCH, 115 (1991), p. 852: Brief reference to recent epigraphic finds [see supra $\mathrm{n}^{\text {os }} 7.105$ and infra $\mathrm{n}^{\circ} 183$ ]. [ES]

179) R.W. PARKer, Potamon of Mytilene and bis Family, in ZPE, 85 (1991), p. 115129: In his study of the epigraphic dossier concerning the orator and politician Potamon of Mytilene and his family (1st c. AD) [cf. supra $n^{\circ}$ 1], P. also refers to Potamon's religious activities, especially those in the imperial cult. Potamon held the hereditary priesthood of Roma and Augustus for lifetime. The preeminent role of Potamon's family in the religious life of Mytilene through the ages is also underlined by the activities of the female members of his family, who figured prominently in the cult of Etephila. [ES]

180) A. Patrianakou-ILIAKI, in $A D, 42$ B1 (1987) [1992], p. 107 [BE 1993, 60]: P. reports the finding of the boundary stone of a sanctuary of [De]meter in Melissia (Attika, near the deme of Phlya, 2nd c. BC), perhaps the sanctuary mentioned by PAUS. 1, 31, 4 and PLUT., Them. 1, 4. [However, the stone does not seem to be broken on the left side, so that the

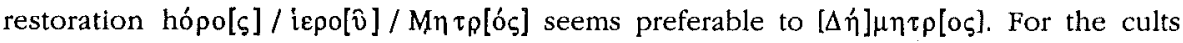

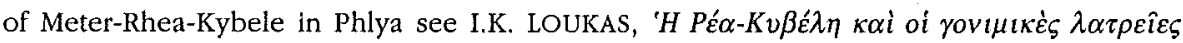
$\tau \hat{\eta} \varsigma \Phi \lambda v \alpha \varsigma$, Chalandri, 1988]. [AC]

181) M. PAz DE HOz, Theos Hypsistos in Hierokaisareia, in EA, 18 (1991), p. 75-77 [BE 1993, 490]: Ed. pr. of a dedication to Theos Hypsistos (Hierokaisareia, 3rd c. AD). Sixteen attestations of Theos Hypsistos and one for Thea Hypsiste are known so far from Lydia. P. rightly rejects the Jewish origin of the cult in this area. The name of this deity

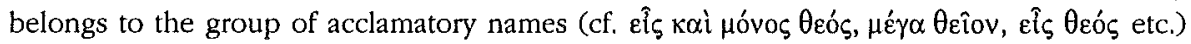
well attested in the pagan cults of Asia Minor. [AC]

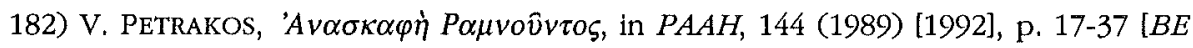
1993, 59. 240]: Ed. pr. of 16 inscriptions from the fortress and the Nemesis sanctuary at Rhamnous. IG $\mathrm{II}^{2} 2869$ and 3 new texts record dedications to Zeus Soter and Athena Soteira by strategoi (1-4, late 2 nd-1st c.). The offering of sacrifices to these deities by the military personnel in Rhamnous was already known from 2 demotic decrees. The sacrifice was followed by a contest of lampadephoria; the dedications probably consisted of bronze torches. NO 5 is a dedication to Demeter and Kore by a strategos (3rd c. BC); the cult of these goddesses was already attested in Rhamnous. An interesting demotic decree (15, after 262/61) establishes a sacrifice for Antigonos Gonatas and mentions his

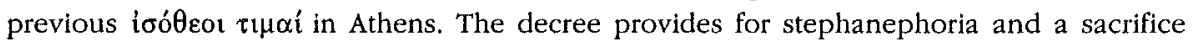
to be offered on the 19th of Hekatombaion during the athletic agon of the Great Nemesia, thus attesting for the first time the date of this festival. A fragmenary inscription (17, 2nd c. BC) probably concerns repairs in a sanctuary (of Nemesis?). [AC]

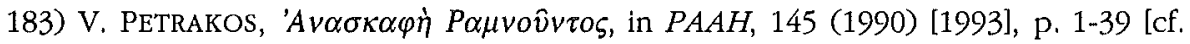
Ergon, 1990, p. 4-9; $B E$ 1991, 237]: Ed. pr. of inscriptions from the fortress and the sanctuary of Nemesis at Rhamnous. An honorific decree of soldiers serving at Aphidna for their strategos mentions the religious duties performed by him: He had sacrificed to Themis and Nemesis (cf. $n^{\circ} 19$, late 3 rd c.) and had offered the sacrifice $\dot{\varepsilon} \xi ı$ เ Aphrodite Hegemone; the stele was set up in the sanctuary of Aphrodite Hegemone, a 
protector of the troops, in Rhamnous $\left(\mathrm{n}^{\circ} 1,222 / 21 \mathrm{BC}\right)$; her sanctuary is mentioned in another decree $(6, \mathrm{ca} .220 \mathrm{BC})$. The other texts include a dedication to Heros (i.e. the Heros Archegetes of Rhamnous, 4, 4th c. BC), a herm dedicated to Hermes, protector of

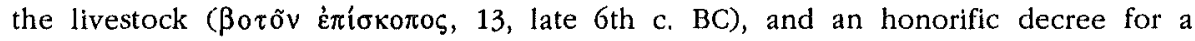
strategos, whom the hieropoioi should invite to the sacrifice offered to Nemesis (2, late 3rd c.). [AC]

*184) A. Petropoulou, Protbysis and Altar: A Case Study, in Espace sacrificiel, p. 25-31: Thorough study of a lex sacra from Epidauros (W. PEEK, Inschriften aus dem Asklepieion von Epidauros, Berlin, 1969, p. 138-139 $\mathrm{n}^{\circ} 336$, sanctuary of Apollon Maleatas, 4th c. BC). P. interprets the prothysis mentioned in this text as a double sacrifice offered to Asklepios and Apollon by those about to undergo an incubation. This sacrifice included bloodless $\pi \rho 0 \theta \dot{v} \mu \alpha \tau \alpha$ valued at 3 obols. P. identifies the altars, on which the prothymata were placed, with the numerous small altars found at the center of Asklepios' sacred precinct. She identifies the altar used for the sanguinary prothysis (holokautoma) with the altar whose foundation was found to the west of building E (6th c. BC). Here Asklepios may have received 'heroic' sacrifices. This altar was still used for sacrifices of a chthonic character, probably performed at night, after the new 4th c. altar was built to the east of the temple. [AC]

185) A.B. Petropoulou, $\Sigma v v \theta \eta \dot{\kappa} \eta$ 'A $\pi \tau \varepsilon \rho \alpha i \omega v \kappa \alpha i$ 'E $E \varepsilon v \theta \varepsilon \rho v \alpha i \omega v$, in Eleutherna, p. 51-68 [BE 1992, 362]: Ed. pr. of a fragmentary treaty of alliance between Eleutherna and Aptera (Crete, e. 2nd c. BC). One of the clauses states that the oath of the treaty should be taken every year by the ephebes who enter the citizen-body (1.25-28); similar clauses are vey common in Cretan treaties. [AC]

186) G. PETZL, Die Inschriften von Smyrna. Tell II, 2; Addenda, Corrigenda und Indices (IGSK, 24, 2), Bonn, 1990 [BE 1991, 7. 217; SEG 40, 1026]: The last volume of the inscriptions of Smyrna contains some new texts (marked with an asterisk):

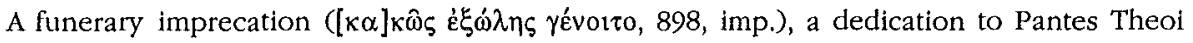
( $* 903$, late Hell.), and a boundary stone of a sacred temenos of Aphrodite Stratonikis (p. 377, 723 c, cf. I.Smyrna 723 a and b); the last text states that the revenues from this land should be added to the sacred revenues of Aphrodite (no date). P. also presents texts known from J. KEIL's drawings (probably previously unpublished). Among them dedications to Herakles (XXX, 2nd c. BC) and Meter (XXIV, imp.), the statue of an eagle dedicated to Zeus (XL, 1st c. BC), altars dedicated to Agathos Daimon and Agathe Tyche (XXVIII, 1st c. BC), and Hadrian (XXXII, called Soter and Ktistes), and grave inscriptions providing for the payment of fines in case of violation (IV, VII, XXIII, imp.). [AC]

187) G. PETZL, Zum Brief Seleukos'I., C.B. Welles, Royal Correspondance Nr. 5 (Griecbiscbe Inscbriften aus dem Nacblass G. Cuppers), in Atalay Memorial, p. 145-152 [BE 1992, 419]: Reedition, on the basis of old drawings of G. CUPPER (17th c.), of a letter of Seleukos I to Miletos; P. offers a new restoration of 1. 21-24, which concern the sending of dedications to the sanctuary at Didyma. [ES]

188) G. PETZL, Nachtrag zu SEG 37, 1001, in EA, 18 (1991), p. 90 [BE 1993, 498; SEG 40, 1050]: In the 'confession inscription' $E B G R$ 1987, 87 [cf. $E B G R$ 1990, 53; now G. PETZL, in $E A, 22,1994, \mathrm{n}^{\circ}$ 59] $\mathrm{P}$. now reads $\pi \varepsilon \rho\llcorner\kappa \rho v \beta o v ́ o n s$, confirming a conjecture made by D. HARVEY $[E B G R 1990,125]$. The sinner was punished, because she had tried to conceal the power of the god. $[\mathrm{AC}]$ 
189) M. PHILEmonos, in $A D, 42$ B2 (1987) [1992], p. 593: P. presents the pedestal of a statue dedicated to Phosphoros [Artemis ?] by a man who had been saved from captivity in Kilikia, in fulfillment of his vow (Rhodes, 2nd c. BC). [AC]

190) F. PIEJKO, Decree of the Ionian League in Honor of Antiocbos I, ca. 267-262 B.C., in Pboenix, 45 (1991), p. 126-147 [BE 1992, 391]: New [often too speculative] restorations of the decree of the Ionian League about the foundation of a festival in honor of Antiochos I (OGIS $222=$ I.Erythrai 5041 . 34-36). An interesting suggestion is that the money for the sacrifices was distributed to the various poleis of the league (1. 4-6); besides the festival celebrated by the league in one of its cities, all members may have held their own separate festivals. [AC]

191) F. PIEJKO, Seleucus II and Ilium, in CEM, 42 (1991), p. 111-138 [BE 1993, 432: $P$. reedits five fragmentary inscriptions from Ilion, which in his opinion concern Seleukos II Kallinikos: a decree establishing a sacrifice (euangelia) for Seleucus II (ca. 246/244 BC, I.llion 35), an honorific decree for Laodike (I.Ilion 36), a honorific decree for Seleukos (I.Ilion 38), the inscription on statue of Seleukos (I.Ilion 62), and an honorific decree for the king (ca. 243, I.Ilion 31), which according to P. concerns Seleukos II and not the founder of the dynasty. Associating a hymn which calls Seleukos a son of Apollon (I.Erythrai $205=L S A M 24$ B) with Seleukos II and not Seleukos I, P. concludes that no testimony on the Apollonian consanguinity of the Seleucids is anterior to the reign of Seleukos II. [Many restorations are arbitrary, and the arguments about the chronology of these texts anything but conclusive]. [AC, ES]

192) F. PIEJKo, Antiochus III and Ilium, in AfP, 37 (1991), p. 9-50: Reedition with many restorations and a commentary of a decree of Ilion (I.Ilion 31), which according to P. concerns the cult of Antiochos III and not Antiochos I (280 B.C.), as scholars have generally believed. [ES]

193) F. PIEJKO, Antiochus III and Teos Reconsidered, in Belleten, 212 (1991), p. 13-69

[BE 1992, 396]: P. attempts a new restoration and interpretation of the dossier of inscriptions concerning the relations between Antiochos III and Teos and the asylia of the city [P. HERMANN, in Anadolu, 9 (1965), p. 29-159]. He holds that "the initiative for the Teian asylia apparently proceeds from the city itself and does not seem to result from any prior royal grant. The intense propaganda blast, made by Antiochos of his own recognition of the asylia, was the enticement and the reward for the submission of Teos." [ES]

*194) V. Pirenne-Delforge, Le culte de la persuasion. Peitbô en Grèce ancienne, in RHR, 208 (1991), p. 395-413 [BE 1992, 48]: P. offers an excellent study of the various attestations and forms of the cult of Peitho in Greece, along with its political and erotic connections. Literary testimonia attest this cult in Athens, Megara, Argos, and Sikyon; the inscriptions ( $p, 412-413$ ) add Thasos, where a sanctuary of Peitho is attested already for the 5th c. BC (IG XII 8, 360, a horos-inscription), Mytilene, Paros, Olynthos, and Rhodes. The inscriptions from Thasos and Mytilene prohibit the sacrifice of a goat or a piglet. Peitho's cult is usually associated with that of Aphrodite and Hermes, deities often regarded as protectors of magistrates. Peitho's cult in this context underlines the need for concord and eloquence in civic offices. [AC, ES] 
195) H.W. PlekET, Review of G. PETZL, Die Inschriften von Smyrna II.1, Bonn, 1987,

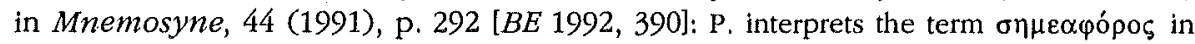
I.Smyrna 741 as a 'carrier of a standard with the portraits of the deities'; the expression

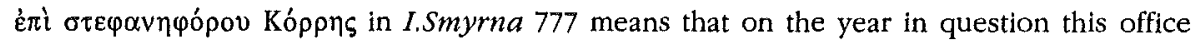
was held by a woman called Korre, not by the deity Kore. [AC]

196) H.W. PLEKET ET AL,, in SEG, 38 (1988) [1991], p. 483-484, $n^{\circ} 1585$ : On the basis of published photos, the editors of $S E G$ transcribe the inscriptions on a mosaic with Dionysiac representations (Diokaesaraea, Palaestina, 3rd c. AD). [AC]

197) H.W. PlekET ET Al., in SEG, 40 (1990) [1993], p. 187, $\mathrm{n}^{\circ}$ 601: Presentation of a dedication to Heros Irsaios (the Thracian rider god, Oituz, Moesia, imp). The text has been published in periodicals not accessible to us (C. MATEI, in Thracologica, 6, 1988, p. 159-160; C.C. PETROlESCU, in SCIV, 40, 1989, p. $399 \mathrm{n}^{\circ}$ 509). [AC]

198) G. PUGliese CARRATElli, La norma etica degli Asklapiadai di Cos, in PP , 46 (1991), p. 81-94: A short but very informative overview of the story of the koinon of the Asklapiadai of Kos based on the epigraphical and literary sources, with special reference to their ethics. [ES]

199) G. PUGliese CARRATELli, Epigrafi dal tetrapilo di Rodi, in ASAA, 64/65 (1986/87) [1991], p. 267-293 [BE 1993, 380]: Publication of inscriptions found in secondary context at the Roman tetrapylon of Rhodos. Dedications of statues of local officials and distinguished women to the gods (1-7, Hell.); a boy-winner in the dolichos race at the Nemea ( 8 , late 4th c. BC); mention of a priest (24); a dedication by the crew of a warship (16, Hell.). A series of texts refers to honors bestowed by local cult associations to various persons and adds to our knowledge of the cult associations in Hell. Rhodos:

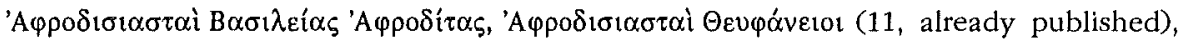

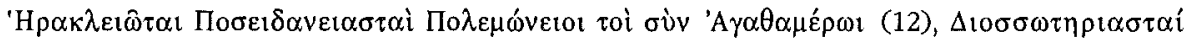
(19) [cf. the remarks of PH. GAUTHIER, in $B E$ 1993, 380]. [AC]

200) W. RADT, Pergamon Vorbericht über die Kampagne 1990, in $A A, 1991$, p. 399432 [ $B E$ 1992, 380]: R. mentions (p. 423) a new altar dedicated to Poseidon Aigaios Asphaleios (Pergamon, imp.) [see the restoration suggested by C. BRIXHE - A. PANAYOTOU, in $B E$ 1992, 380: 'A $\sigma \varphi \alpha \lambda \varepsilon i[\omega t]$ ]. This is the second dedication to Poseidon known from Pergamon. [AC]

201) J. ReYNOLDS, Epigraphic Evidence for the Construction of the Theatre: 1st c. B.C. to mid 3rd C. A.D., in Aphrodisias Papers, 2, p. 15-28 [BE 1992, 436]: In her presentation of the epigraphic evidence for the theater of Aphrodisias, R. mentions (p. 21 note 29) an unpublished dedication to Nemesis Epekoos. An appendix presents a provisional publication of 9 inscriptions. They attest that the building works in the theater were dedicated to Aphrodite (p. 23-24, $n^{\text {os }}$ 2. 4. 5), the emperors (p. 23-24, $n^{\text {os }} 2$. 4 , p. $26 \mathrm{n}^{\circ} 1$, p. 28), the Demos (p. 24, $\mathrm{n}^{\circ} 4$ ), and the Patris (p. 26, $\mathrm{n}^{\circ} 1$, p. 28). One of the dedicants was Zoilos, high priest of the imperial cult and priest of Aphrodite for lifetime (p. 26, $\mathrm{n}^{\circ} 1,2 \mathrm{nd} / 3 \mathrm{rd}$ c.); another text honors a high priest of the imperial cult (p. 26, $\mathrm{n}^{\circ} 2$, $2 \mathrm{nd} / 3 \mathrm{rd}$ c.). $[\mathrm{AC}]$

202) M. RICL, Le sanctuaire des dieux Saint et Juste à Yaylababa Köyü, in Ziva Antika, 40 (1990) [1992], p. 157-177 [BE 1993, 549]: Ed. pr. of 30 reliefs dedicated to the gods Hosios kai Dikaios in their sanctuary at Yaylababa Köyü (near Kotiaeion, Phrygia 
Epiktetos, 3rd c. AD); [cf. infra $\mathrm{n}^{\circ}$ 204]. All of them are broken (perhaps already in ancient times). The representations on the reliefs show that in this sanctuary two separate masculine divinities ('angels' of Helios) were worshipped under this name, not one divinity with two epithets (as e.g. in Maionia). Some dedications bear representations of domestic animals; 16 reliefs are inscribed. The inscriptions name the gods and the reason for the dedication, i.e. the protection offered or hoped to be offered

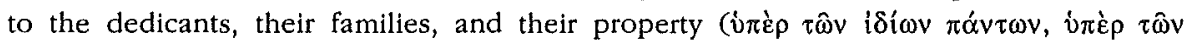

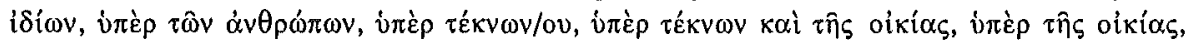

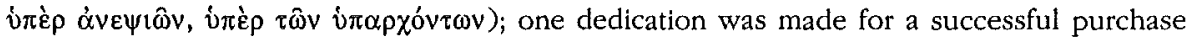

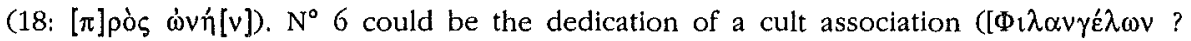

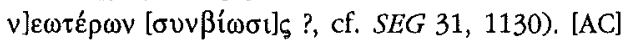

203) M. RICL, Nouveaux monuments votifs de Phrygie, in EA, 17 (1991), p. $73-77$ [BE 1992, 489]: Presentation of six dedications to Zeus Ampelites preserved in the Museum of Kütahya (Phrygia, imp.). The decoration of the dedications to this Phrygian deity implies that they were offerings of peasants concerned with the security of their belongings, especially their livestock [C. BRIXHE - A. PANAYOTOU, in $B E$ 1992, 489

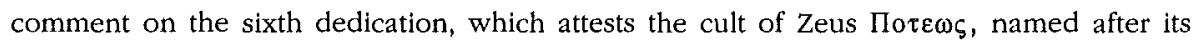
founder]. [AC]

*204) M. RICL, Hosios kai Dikatos. Première partie: Catalogue des inscriptions, in $E A, 18$ (1991), p. 1-70 [BE 1993, 545]: The first part of this important study on the cult of Hosios kai Dikaios presents the relief dedications (111 monuments, 109 of them inscribed, 6 inedita) basically from Lydia and Phrygia (cf. the distribution maps). The catalogue contains inscriptions (basically dedications) from Northeast Lydia and Maionia (1-18), Phrygia Epiktetos (19-28), the villages between Dorylaion and Nakolea (29-35), Nakolea (36-45), Kotiaieion (46), the sanctuary at Yaylababa Köyü (47-78) [cf. supra $\mathrm{n}^{\circ}$ 202], Aizanioi (79-84), the rest of Phrygia and Galatia (85-98), Lykaonia (99), Pamphylia (100), Bithynia (101), Mysia (102-103), Troas (104), Ionia (105), unknown places in Asia Minor (106-107), with only four texts from places outside of Asia Minor (Gorgippia, Anchialos, Ulpia Nicopolis ad Istrum, Thasos, 108-111). R. mentions 6 unpublished dedications, without giving the text (Museum of Manisa: 17. 18; Bayramlar: 94; vicinity of Perge: 100; Germa: 102; Bozen: 103). One of the unpublished texts (103) contains an imprecation. [AC]

205) J. RODRíguez SOMOLINos, Le phis ancien oracle d'Apollon Didyméen, in EA, 17 (1991), p. 69-71 [BE 1992, 417; 1993, 481]: R. proposes a plausible restoration of Milet I 178 , probably the oldest among the three archaic oracles known from Didyma (6th/5th c.), written in prose. The text confirms that oracles were given at night. According to the new restoration, this oracle was the response to a second consultation (cf. क́s $\tau$ in

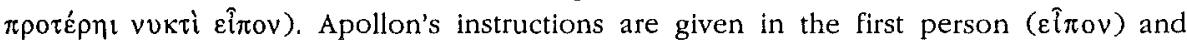
probably concern the cult of Artemis (Delphinia ?, Pythie ?) at Didyma. [AC]

*206) G.M. ROGERs, The Sacred Identity of Ephesos. Foundation Myths of a Roman City, London-New York, 1991: Exhaustive study of I.Ephesos 27 (text and translation in p. 152-185), which records the foundation of C. Vibius Salutaris (AD 104). Notice the detailed discussion of the procession of statues, whose aim was to dramatize the historical identity of Ephesos and to further the acculturation of the youth by educating them in the historical traditions of the city [cf. supra $\mathrm{n}^{\circ}$ 42]. In appendices (p. 186-188), R. 
gives examples of analogous foundations and underlines the differences between the foundation of Salutaris and that of Demosthenes at Oinoanda [EBGR 1988, 193; cf. infra $n^{\circ} 207$; not only was the foundation in Ephesos of larger scale, but its procession was also planed to coincide with an already existing festival of Artemis, whereas Demosthenes founded a new festival. [AC]

207) G.M. ROGERS, Demosthenes of Oenoanda and Models of Euergetism, in JRS, 81 (1991), p. 91-100: R. discusses the recently published inscription recording the foundation of the festival Demostheneia by Demosthenes in Oinoanda [EBGR 1988, 193]. He observes that there is a gap of one year between the first proclamation of Demosthenes (25 July AD 124) and the preliminary proposal about the festival (5 July AD 125); the original proclamation and the final proposal differ in two basic points, i.e. the rôle of imperial cult and the active participation of the villages and farmsteads in the territory of Oinoanda. Whereas the original proclamation provided for a typically Hellenistic festival, only the final proposal provides for the donation of a crown bearing the images of emperor Hadrian and Apollon and for the procession of civic officials, including the priest and the priestess of the imperial cult and the representatives of 35 villages. $R$. interprets these differences as the result of negotiations, the product of a 'creative tension' between the Hellenistic system of reference and the new elements. His persuasive conclusion that festivals were negotiated, not imposed, provides new insights to the way festivals expressed the self-representation of civic communities Icf. supra $n^{\text {os }} 42$ and 206]. [AC]

*208) L. ROLLER, The Great Mother at Gordion: The Hellenization of an Anatolian Cult, in JHS, 111 (1991), p. 128-143 [BE 1992, 509]: The iconography and the inscriptions related to the cult of the Great Mother at Gordion (Phrygia), a main center of Kybele's cult, show an abrupt break with the earlier tradition in the 3rd c. BC. The Phrygian images of the deity, with their specific elements (facial features, costume, attributes, presence of birds of prey, a young male companion), do not develop into Greek forms (lion, tympanon, a torch-bearing female companion), but simply disappear. The new iconographic elements of the $3 \mathrm{rd}$ c. derive directly from the Greek tradition. The goddess became associated to the cult of Greek deities, as can be inferred from dedicatory inscriptions to the Muses (on the back of the throne of an alabaster statuette of the goddess) and the Agathe Tyche (on a small pedestal, p. 134, 3rd c.). However, some traditional elements, such as the lack of temples or major shrines and the absence of Attis' cult, still persisted. [AC, ES]

209) V.J. Rosivach, IG $2^{2} 334$ and the Panathenaic Hekatomb, in PP, 46 (1991), p. 430-442: R. discusses the sacrificial regulations mentioned in the Attic decree about the Panathenaic festival (IG II $\mathrm{I}^{2} 334=L S C G 33 \mathrm{~B}, 1.8-27$ ) (now reedited in The Athenian Agora, XIX, L $7=i m f r a n^{\circ} 270$ ]. The sacrifices are to be distinguished into two groups: a) Two sacrifices, one offered to Athena Hygieia, the other offered in the 'old temple' (1. 816); the meat of the sacrificial animals was distributed; b) a second set of sacrifices (1. 1627), for which the victims should be purchased with revenues from the leasing of the land called Néa; these victims were lead in a procession to the Akropolis, where they were sacrificed and their meat was distributed. $R$. argues that the second group of sacrifices cannot have been introduced before the 330's, since the land called Nea can be identified with the territory of Oropos given back to the Athenians by Philip in 338/7 [cf. M.N. WALBANK, in infra $\mathrm{n}^{\circ} 270$, p. 186]. Accordingly, the description of these 
sacrifices cannot be used as evidence for the interpretation of the Parthenon frieze or for the procession of the Panathenaia before the late 4th c. BC. [ES]

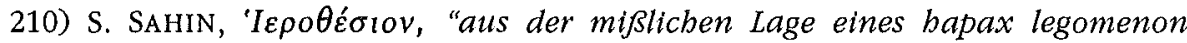

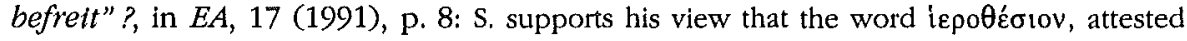
in the 'lex sacra' of Antiochos' I of Kommagene at his monument in Nemrud Dag, is a word created in Kommegene at Antiochos' time. He doubts if one should replace the word

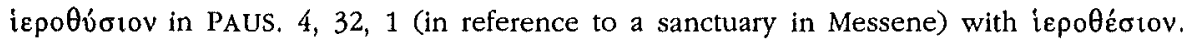
[AC]

211) S. SAHIN, Bemerkungen zu lykischen und pampbylischen Inschriften, in EA, 17 (1991), p. 113-136 [BE 1992, 461]: Arykanda: S. found and republishes (p. 119-122) the grave epigram for the architect Zosimos (TAM II 3, 799, 2nd c. AD) [cf. S. SAHIN, Die Inschriften von Arykanda, Bonn, 1994, p. 101-102 $\mathrm{n}^{\circ}$ 108]. Zosimos' activities are

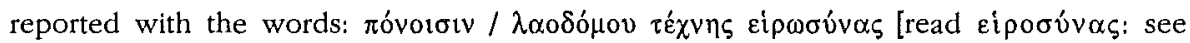

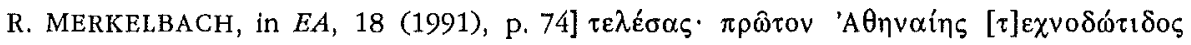

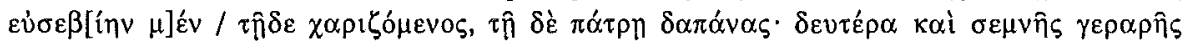

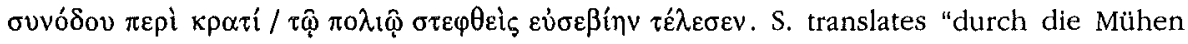
der den öffentlichen Bau betreffenden Kunst [MERKELBACH, o.c., corrects the translation: "die mit Steinen bauende Kunst"] vollendete er die priesterlichen Dienste; zuerst (den Tempel ?) der Athena, welche die Künste gibt [for this epithet of Athena cf. L. DuBoIs, in $B E$ 1993, 213], indem er ihr seine Frömmigkeit schenkte, der Vaterstadt aber seine Aufwendungen; dann erfüllte er seine fromme Tat auch für den ehrwürdigen

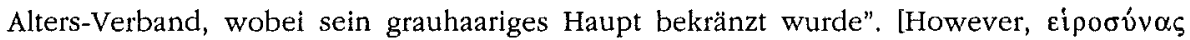
$\tau \varepsilon \lambda \varepsilon \sigma^{\sigma} \alpha \varsigma$ implies that Zosimos held priestly offices. Perhaps the text is not referring to the construction of temples of Athena and for a synodos, but narrates that Zosimos paid the summa bonoraria for his offices with the earning of his work as an architect. He served as a priest of Athena and as a priest of a synodos; he received a crown as a symbol of his office, not for his building activities]. Grottos of Karain (Pamphylia): S. publishes (p. 126-132) 8 inscriptions referring to the cult of Meter Oreia/Kybele (imp.); 7 texts had been published by G. MORETTI, in ASAA, 6/7 (1923/24), p. 547-554 (cf. SEG 6, 718723; CCAA I, n ${ }^{\text {os }} 751-754$ ), one text (8) is new. $S$. gives new readings and restorations to the old texts. Two texts (here $\mathrm{n}^{\mathrm{os}} 7$ and 8 ) show that the mystery cult of Meter Oreia Thea Epekoos was exercised by a thiasos, whose head bears the title archithiasites, archimystes or mysteriarches. The thiasos built for the godess an $\alpha v \alpha v \lambda \iota \tau$ in $\rho \imath v$, probably a room of worship within the cave [cf. L. DUBOIS, in BE 1993, 187: "espace cultuel (?)"]. Aspendos: According to S. a text published by C. BRIXHE - R. HODOT, L'Asie Mineure du Nord au Sud, Nancy, 1988, $\mathrm{n}^{\circ} 40[E B G R$ 1988, 23] is a dedication to Germanicus by a a high priest of the imperial cult. Etenna: Ed. pr. of a dedicatory inscription on the statue of a certain Seleukos, ktistes of Etenna (Pamphylia, 1st c. AD); it is not clear if this heroised Seleukos was a king of the Seleucid dynasty or an other person by that name. Ed. pr. of an honorific inscription for a high priest of the imperial cult (2nd c. AD). [AC]

212) S. SAHIN, Inscbriften aus Seleukeia am Kalykadnos (Silifke), in EA, 17 (1991), p. 139-164 [BE 1992, 537]: Ed. pr. of 5 inscriptions from Seleukeia on the river Kalykadnos: 1) An honorific inscription for T. Aelius Aurelius Maron, xystarches and periodonikes in wrestling at 44 thematic agons and 32 agones stephanitai, in Olympia, Rome (Capitolia), Delphi (Pythia), Korinth (Isthmia), Athens (Olympic, Panhellenic, and 
Panethenaic agons), Aktion, Neapolis (Sebasta), Puteoli, Rhodes (Haleia), Antiocheia, Pergamon, Tarsos, Argos (2nd c. AD) [R. KASSEL, supra $\mathrm{n}^{\circ} 125$, proposes some corrections in the text of the epigram], 4) Inscribed pillar with the inscription $\Delta$ iò $\Sigma \omega \tau \hat{n} \rho \circ \varsigma$ kí $\omega v$ (imp.); the pillar may have supported a statue of Zeus Soter [C. BRIXHE - A. PANAYOTOU,

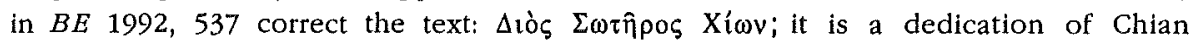
mercenaries at the fort of Meydancikkale, ca. $240 \mathrm{BCl}$. 6) Dedication of a relief to Tyche (imp.). [AC]

213) S. SAHIN, Forschungen in Kommagene I: Eptgraphik, in EA, 18 (1991), p. 99-111 [BE 1993, 609. 614]: 1) Ed. pr. of an inscription carved on the rock, probably in the area of a sanctuary, recording the activities of the architect Ariarames (near Adiyaman, Kommagene, ca. 36-20 BC), who had finished statues of Zeus Soter and other deities, left

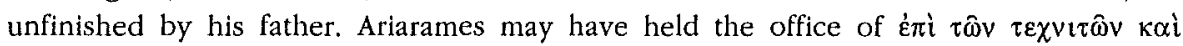

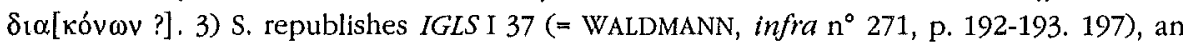
altar dedicated to the kings of Kommagene and serving as the boundary stone of a temenos. 4) Ed. pr. of a dedication of statues of gods, perhaps in a sanctuary dedicated to the cult of the kings of Kommagene (Ancoz, 2nd c. AD). 4) Reedition of IGLS I 86 (= WALDMANN, infra $\mathrm{n}^{\circ} 271$, p. 72.201 , Maras), an Aramaic or new Hettite stele (8th/7th c. BC), which had been found by the strategos Zarieris and dedicated to Theos Epekoos [i.e. Zeus Dolichenos; cf. C. BRIXHE - A. PANAYOTOU, in $B E$ 1992, 609]. [AC]

214) S. SAHIN, Forscbungen in Kommagene II: Topograpbie, in EA, 18 (1991), p. 114131: S. discusses certain problems related to the hierothesion of Antiochos $I$ of Kommagene at Nemrud Dag using the inscription recording his religious reforms (OGIS $383=\mathrm{H}$. WALDMANN, Die kommagenischen Kultreformen unter König Mithradates $I$. Kallinikos und seinem Sobne Antiochos I., Leiden, 1973, p. 63-71) and recent archaeological discoveries. His study shows that the hierothesion was built on an older place of worship and that its construction was never completed; it is doubtful if worship ever took place there, since the hiera trapeza mentioned in the inscriptions (1. 146-148) was never constructed. However, it seems certain that Antiochos' body was buried in the tumulus. [AC]

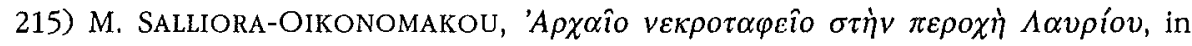
$A D, 40$ A (1985) [1991], p. 90-132 [SEG 40, 174]: Ed. pr. (p. 97, 128-132) of an inscription recording the lease of a mine named after Hermes ( $\mu \varepsilon \dot{\varepsilon} \tau \lambda \lambda \lambda_{0 \nu}$ 'E $\rho \mu \alpha i$ íóv) in Laurion (Maroneia ?, 5th c. BC) [or rather 4th c. BC; cf. $S E G$ 40, 174]. [AC]

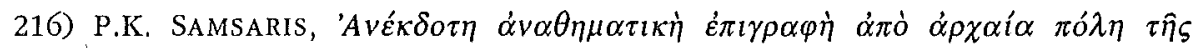

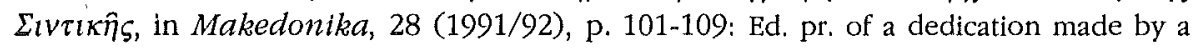
woman to Eileithyia (Herakleia Sintike?, 4th/3rd c. BC). Other sanctuaries of Eileithyia are known in Dion and Amphipolis. [AC]

*217) M. SASEL KOS, Draco and the Survival of the Serpent Cult in the Central Balkans, in Tyche, 6 (1991), p. 183-192: In her brief study on the religious significanse and the worship of snakes and eels in the ancient Balkan, $S$. discusses two known epigraphic attestations of the cult of Drakon and Drakaina. The first text is a dedication to Drakon from the region of the Deuropes in Paionia (area of Prilep, 1st c. AD), where the serpent cult had deep roots. The text is carved on the rock, above a representation of a snake rising above a bowl containing an egg. The second text, from the territory of Scupi (3rd c. AD), is a Latin dedication to Alexander (i.e. Alexander the Great, and not 
Alexander of Abounouteichos) and to the couples Jupiter-Juno and Dracco-Draccena (sic). It is the only attestation for the couple Drakon-Drakaina; in other areas a joint cult of Drakaina and Zeus Ktesios, Meilichios, and Philios (i.e. former snake gods) is attested. The cult of Drakon is otherwise attested in North Africa and Rome (p. 188 note 23). [AC]

*218) D. Schaps, When is a Piglet not a Piglet?, in JHS, 111 (1991), p. 208-209: S. argues that the $3 \delta \varepsilon \lambda \varphi \alpha$ xi $\alpha$ mentioned in the accounts of the hieropoioi of Delos in relation to the sacrifice offered during the Thesmophoria were not piglets, but rather full-grown or nearly full-grown pigs, perhaps castrated. [ES]

*219) E. SCHWERTHEIM, Iupiter Dolichenus, der Zeus von Doliche und der kommagenische Königskult, in Asia Minor Studien, 3 (1991), p. 29-40 [BE 1993, 608]: With the help of epigraphic and archaeological testimonia, S. studies the origins of the cult of Iupiter Dolichenus. Zeus Dolichenos was originally the weather god of the city of Doliche in Kommagene; in the course of Hellenistic times he acquired the character of a local god of all Kommagenians (deus Commagenus), the god of the region where iron was found. His cult was associated with that of other local deities, as can be inferred from representations of the dexiosis between Zeus Dolichenos and other male deities (among them the local god of Soumana). A new element came into the cult, when Zeus Dolichenos became associated with the cult of the royal house of Kommagene (at the latest under Antiochos I, ca, $62 \mathrm{BC}$ ), his sanctuary at Dülül Baba Tepe being transformed into a cult center for the royal cult. The cult of Iupiter Dolichenus was introduced into the West by soldiers, merchants etc., void of a soteriological aspect, but mainly as a god combining the elements of an old weather god, a city-god, and a royal god. The testimonia about the cult associations of Jupiter Dolichenis in the West support this view; it seems that the administration of the cult in Hell. Kommagene influenced the organisation of the cult in the West. [AC]

220) P. SIEWERT, Die fribe Verwendung und Bedeutung des Ortsnamens 'Olympia',, in $M D A I(A), 106$ (1991) [1992], p. 65-69 [BE 1993, 110]: An archaic helmet (unknown provenance; late 7th c. BC: H. PFLUG, in Antike Helme, Sammlung Lipperbeide und andere Bestände des Antikenmuseums, Berlin, Berlin, 1988, $\mathrm{n}^{\circ} \mathrm{K}$ 19) with the inscription 'O $\lambda \cup \pi \alpha \dot{\alpha} \delta \varepsilon$ ('dedicated to Olympia') is the earliest epigraphic attestation of the place

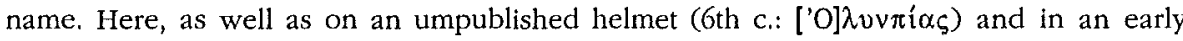

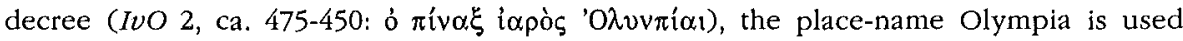
instead of Zeus' name (cf. an unpublished inscriptions from Olympia: o้ $\delta \varepsilon \pi i v \alpha \xi \not ้ \gamma \alpha \lambda \mu \alpha \tau \tilde{0}$ $\Delta$ tós). In these early testimonia the name Olympia refers to the sanctuary; only later did it replace Pisa as the name of the site. The mention of the name of the sanctuary in a dedication, instead of the name of the divinity, is a rare practice abandoned in the 5 th $\mathrm{c}$. BC. $[\mathrm{AC}]$

221) P. SIEWERT, Staatlicbe Weibungen von Kesseln und anderen Bronzegefäßen in Olympia, in MDAI(A), 106 (1991) [1992], p. 81-84 [BE 1993, 111]: S. studies the ten inscribed bronze vases dedicated by communities to Zeus at Olympia (6th-early 4 th $\mathrm{c}$. BC: IvO 244. 257. 258. 930; SEG 11, 1204; 25, 462. 1164; $A A A, 13,1980$, p. 235ss.; three inedita) [cf. supra $\mathrm{n}^{\circ}$ 82]. Except for a single Spartan dedication, all the offerings were made by communities located near the sanctuary (Eleans, Amphidoloi, Alasyeis, Akroreioi, Ledrinoi, Skilluntians); this strengthens U. KAHRSTEDT's view that before the 5 th $/ 4$ th $c$. the sanctuary of Zeus in Olympia was administrated by an amphictiony 
formed by the neighbouring communities; Sparta may have occupied a special position.

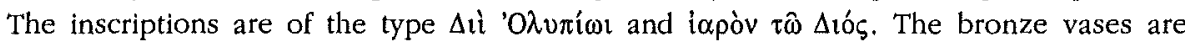
probably thanksgiving offerings for certain revenues, not dedications after military victories. The vases dedicated by the Eleans were used for the mixing, pouring, and cleaning of wine, i.e. these objects must have been used in the worship. [AC]

222) P. SIEWERT, Die Inschriften der Landschaft Eleia obne Olympia, in Acbaia und Elis, p. 105-107 [BE 1992, 5]: Brief presentation of the published and unpublished inscriptions of Elis (with the exception of Olympia). S. mentions 4 dedications and 2 epitaphs which attest the cults of Artemis Limnatis (Kombothékra), Dionysos (Elis, musical agon), and Daidaleia, perhaps identical with the cult of Daidaleia at Mázi (Artemis Daidaleia ?) [or Athena Daidaleia ?: cf. $E B G R$ 1988, 151]. The importance of Dionysos' cult in Koile Elis can also be inferred from the theophoric names Dionysios and Thyion), the festival Thyia, and the month Thyios. [ES]

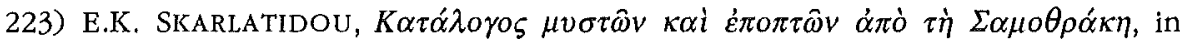
Horos, 8/9 (1990/91) [1993], p. 153-172: Ed. pr. of an inscription probably from the sanctuary of the Great Gods at Samothrake. It contains three texts: An honorific decree and a list of 48 mystai and epoptai (ca. 150-84, Aa), a list of Chian mystai and epoptai, members of the crew of ships patroling the Aegean (ca, 84-61 BC, Ab-B), and a list of three Roman mystai $(67-45, \mathrm{C})$. [AC]

224) W.J. SLATER, Making Crowns for the "Sarapieia", in RA, 1991, p. 277-280: The value of the crowns given to the victors of the Sarapieia in Tanagra and mentioned in the account of the agonothetes (SEG 19, 335, ca. $80 \mathrm{BC}$ ) follow a precise pattern, which enables $S$. to reconstruct the way the goldsmith was paid, i.e. based on a contract between him and the agonothetes. $[\mathrm{AC}]$

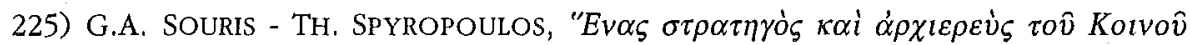

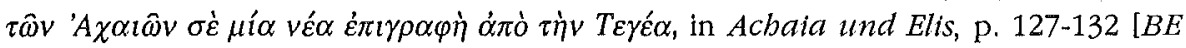
1992, 260]: Ed. pr. of an honorific inscription for Sex. Pompeius Menophanes (Tegea, 3rd c. AD), who held the offices of high priest of the civic imperial cult, high priest for lifetime of the provincial imperial cult in Achaia, and strategos of the koinon of the Achaeans. [ES]

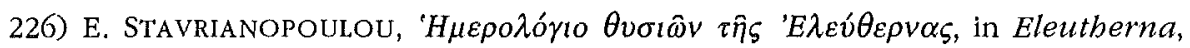
p. 31-50 [BE 1992, 361]: Ed. pr. of four not joining fragments of an important sacrificial calender from Eleutherna (mid or late 2nd c. BC) with exhaustive commentary. The various entries refer to the date of the sacrifice, the place, the deity, the number, sex, colour, kind (ram, ox, billy-goat, sheep, pig), and character of the sacrificial animal

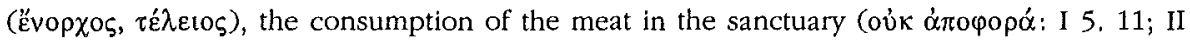

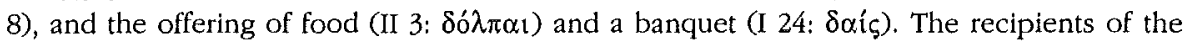
sacrifices were a heros (I 6), Zeus Poliaochos (I 9, first attestation for Crete), a Nymph (I 10: $\tau \hat{\alpha} \mathrm{t} \lambda \hat{v} \mu \varphi \alpha\langle\imath\rangle$ ), Artemis (cf. I 14. 22), Zeus (I 17), the Materes (I 18), [Demeter Megala]rtos (II 3, first attestation for Crete), Zeus Machaneus (IV 5), and possibly Artemis Agrotera (IV 6); both Zeus Machaneus and Artemis Agrotera were already attested in Eleutherna [cf. $E B G R$ 1990, 152]. One of the sacrifices was trieteric (II 7). This fragmentary lex sacra also attests the existence of an Artemision (I 14) and the month name Damatrios (I 7, only here attested on Crete). The very fragmentary state of preservation does not permit the full restoration of any regulation; one of them seems to 
concern sacrifices to be offered viritim ( $\dot{\alpha} v \delta \rho \alpha \kappa \alpha$ s, I 21); another refers to an adyton in a

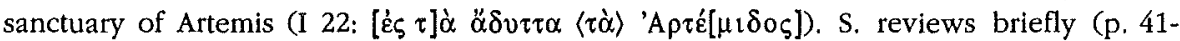
50) the cults of Eleutherna known so far, discussing in detail the cults of Artemis, Zeus, and the Materes. The latter cult, very important in Engyon in Sicily, is now attested also for Crete, which the literary tradition regarded (as it seems correctly) as the place of origin of the Sicilian cult. [AC]

*227) C.M. STIBBE, Dionysos in Sparta, in BABesch, 66 (1991), p. 1-44: S. presents the information about the cult of Dionysos in Sparta (since the 6th c. BC), the site of his temple, the possible historical background of the introduction of his cult (Delphic oracle, rôle of women, agrarian background). He studies in detail the relation between the Spartan 'grave reliefs' and the worship of Dionysos. S. argues that these reliefs and the related clay tablets, which are sometimes inscribed with names, were set up in heroa; the male figure represented on them, with a kantharos in hand, should be identified with Dionysos and not with the heroized dead. Dionysos' representations underline the chthonic aspect of his cult. The goddess represented together with Dionysos on some of these monuments, with a pomegranate in her hand, can be identified with Demeter Chthonia. According to the literary tradition her cult was introduced in Sparta by Orpheus; this brings her cult in connection with the Dionysiac-Orphic movement of the 6th c. S. suggests that the association of these gods with the underworld reveals Egyptian influence (Isis-Osiris), which is also obvious in certain stylistic features of the reliefs (throne with lion-feet, smaller size of the adorants). In classical times the meaning of the representations changed, the god becoming a hero, and the goddess an adorant or a female relative of the deceased. [AC]

*228) J.H.M. STRuBbe, 'Cursed be be that Moves My Bones', in Magika Hiera, p. 3359 [BE 1993, 406. 429]: Thorough study of the pagan funerary imprecations in Asia Minor, especially of those imprecations which clearly specify the punishment awaiting the violator of the tomb. S. discusses the words used to describe the violator of the tomb

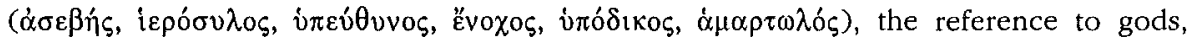

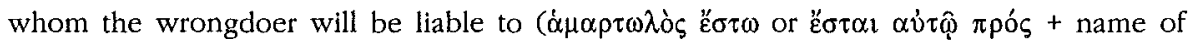
one or more deities), the recording of imprecations in testaments, the use of symbols (raised hands, scepters), the irrevocable character of the curse, and the various curse formulae with special emphasis on the various kinds of punishment wished for the violator of the tomb (death, untimely death, leaving orphaned children and a desolate house, birth of monstrous children, plague, banishment from the homeland, punishment of the violator's family). About thirty different gods are named in the texts. S. shows that the funerary imprecations of Asia Minor represent the fusion of a Greek tradition of nonfunerary public and private imprecations and an Anatolian tradition of protecting the tomb with imprecations. The rarity of funerary imprecations in mainland Greece may be due to different ideas about the dead and the afterlife. [AC]

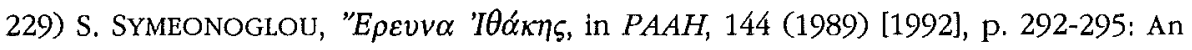
inscription permits the identification of a sanctuary recently found on Ithaka with a sanctuary of Apollon mentioned by Homer (Od. 20, 278). [AC]

230) C. TANRIVER, Some New Texts Recording Occupations, in $E A, 18$ (1991), p. 79-82 [BE 1993, 422]: Ed. pr. of new inscriptions from northwestern Asia Minor, including an honorific inscription for an agonothetes of a $\mu$ ź $\gamma \alpha \varsigma$ agon (2, Bekrili, no date), a dedication 
to an iepòs Bókxos, i.e. the head of a Bacchic association (3, near Daskyleion) [cf. the remarks of C. BRIXHE - A. PANAYOTOU, in BE 1992, 422; on the term Bakchos cf. supra $\mathrm{n}^{\circ}$ 47], and a dedication to Hermes and Herakles by a gymnasiarch (5, vicinity of Teos). [AC]

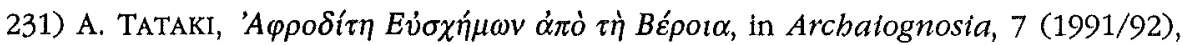
p. 135-140: Ed. pr. of a dedication to Aphrodite Euschemon after a dream (Beroia, imp.). The epitheton of Aphrodite was until now unattested. T. gives a list of other epitheta of this goddess attested in Macedonia (Basilissa, Epiteuxidia, Harmonia, Homonoia, Hypolympidia, Kythereia, Ourania, Paphie, Peitho). The inscription mentions a priest of Aphrodite for lifetime, who also served as a priest of Isis Lochia for lifetime. [AC]

232) J. TEIXIDOR, Interpretations and Misinterpretations of the East in Hellenistic Times, in Seleucid Kingdom, p. 66-78: T.'s study concerns the process of acculturation of Greeks and indigenous populations in the Seleucid kingdom, with special emphasis on the 'interpretatio religiosa' of local beliefs in the light of an alien faith. Examples of this syncretism are the cults of Hadad (mentioned in a Greek dedication from Kafr Yassif, near Ptolemais), Sarapis, and Nabu. Hadad was assimilated with Zeus (Zeus Kyrios at Dura-Europos, Zeus Megistos at Palmyra, Zeus Epikarpios in Hauran). The cult of Sarapis was used as a kind of link between the different Eastern and Western religious spheres; Nabu was assimilated with Apollon. [ES]

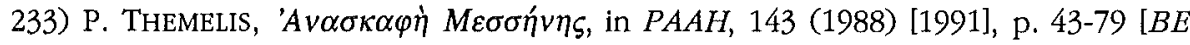
1993, 263]: Presentation of several important texts from Messene lalready reported in $E B G R$ 1989, 86): A Hell. dedication to Acheloos near the fountain Klepshydra (p. 49), a decree about the establishment of an agon on the birthday of the emperor Tiberius ( $A D$

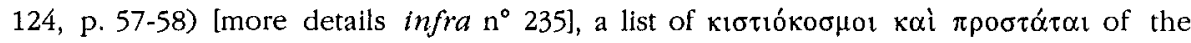
sanctuary of Athena Kyparissia (Hell., p. 62-63), and an inscription mentioning a priest and an agonothetes (p. 64). [AC]

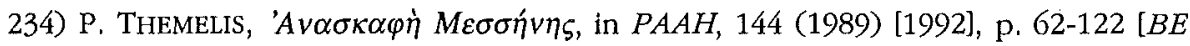
1993, 62. 82]: Presentation of several new inscriptions found in Messene: A dedication to Eleuthyia (p. 91, 4th/3rd c.); dedication of statues of the Messenian heroes Hegemone and Tripas to the gods (p. 110,1st. c, BC) by descendants of the sculptor Damophon. Some texts (pillars, roof tiles, p. 98-99) name eponymous priests of Zeus Ithomatas (Hell., imp.). [AC]

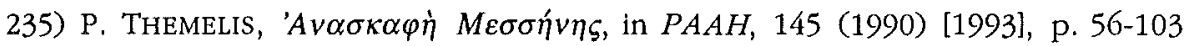
[cf. Ergon, 1990, p. 29-35]: The new important finds from Messene include new fragments of the decree about the establishment of an agon for emperor Tiberius (AD 14, p. 87-91) [cf. infra $\mathrm{n}^{\circ} 233$ ]; $I G \mathrm{~V} 1,1448$ also belongs to this text. The decree provides for an ekecheria of 3 days, a gymnic agon of boys and a horse race of youths; the weapons of the winners were to be dedicated by the priest. In the first, very fragmentary part of the inscription, notice the mention of k $\alpha \tau \varepsilon v \chi \alpha i$ performed by a mantis (1. 17), an oath of office (1. 19), a dadouchos (1. 23), and prayers spoken after a sacrifice of lambs (?, 1. 22). An embassy was sent to Rome with condolences upon Augustus' death $(\lambda \cup \pi \eta \theta \eta \sigma o \mu \varepsilon ́ v \alpha v$

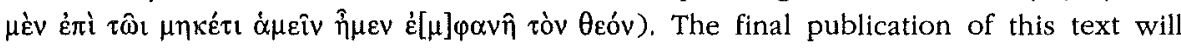
certainly add to our knowledge of the early stages of the emperor's cult in the East. The fragment of a treaty of alliance between Messene and Lysimachos and his allies (ca. 286$281 \mathrm{BC}$, p. 85-86) preserves the oath of alliance, taken by the ephoroi. The oath begins

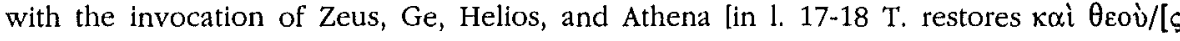




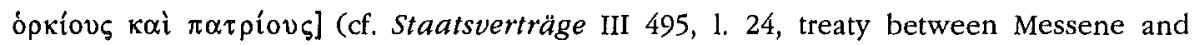

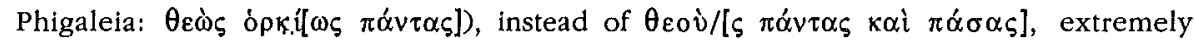
common in this period cf. e.g. Staatsverträge III 429. 463. 468. 481. 492. 552)]. A fragmentary Hell. decree (p. 85-86) mentions the festivals Asklapieia and Basileia and the sanctuary of Messene, which according to $T$. was located in the Asklepieion. [The decree seems to concern the recognition of the festival Asklepieia as an agon mousikos isopythios, hippikos isolympios; see 1. 3-8]. Several other new finds name eponymous priests of Zeus Ithomatas (p. 91-94, 99-100), agonothetai, and hierothytai (p. 99-100,

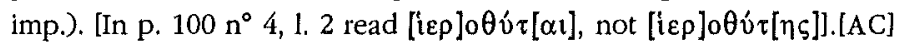

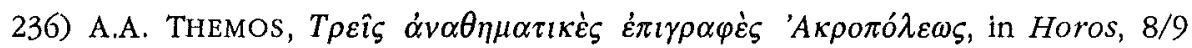
(1990/91) [1993], p. 59-62: Ed. pr. of three dedicatory inscriptions from the Athenian Akropolis; one of them is addressed to Zeus Meilichios (late 4th c. BC), another to Hygieia (by a priest of Asklepios, early 4th c. BC). [AC]

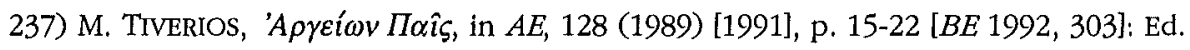

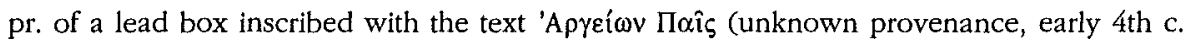
$\mathrm{BC}$ ). The material (lead) and the name in the nominative case suggest a defixio; the box may have contained a 'voodoo doll'. If the box was found in Macedonia (Vergina ?), the person against whom the curse was addressed could have been a member of the Macedonian royal family, which claimed an Argive origin. [AC]

238) S.V. TRACY, Attic Letter-Cutters of 229 to 86 B.C., Berkeley-Los AngelesOxford, 1990 [BE 1992, 16]: In this important contribution to the chronology of Attic inscriptions $T$, proposes a more accurate date for many texts, improves the reading of some texts (e.g. IG $\mathrm{II}^{2} 2436$ records a sacrifice to Apollon; IG $\mathrm{II}^{2} 2944$ mentions an epimeletes of the mysteries), discovers joins and associations of published texts (Agora I $656+6355+1029$ : an honorific decree for prytaneis who performed sacrifices; $I G \mathrm{II}^{2}$ 959+1014: an honorific decree for an agonothetes of the Theseia), and publishes many new fragments from the Athenian Agora, some of them related to res sacrae: a) an honorific decree for an official who offered sacrifices to Dionysos (p. 58-59 $\mathrm{n}^{\circ} \mathbf{1}$, ca. 226$190 \mathrm{BC}$ ) [SEG 40, 97]; b) a list (inventory ?) with names of agonothetai and mention of phialae, probably dedications (p. 76-77, $\mathrm{n}^{\circ} 2$, ca. 210-170) [SEG 40, 151]; c) an honorific decree for a priest with mention of a pannychis (for Asklepios?, p. 104, $\mathrm{n}^{\circ} 1$, ca. 194-147) [SEG 40,108]; d) a fragmentary lex sacra mentioning prohibitions and a fine to be paid to Artemis Phosphoros (p. 105-106, $\mathrm{n}^{\circ}$ 3, ca. 194-147) [SEG 40,123]; e) an honorific inscription for a priest or another official, who offered sacrifices (p. $176 \mathrm{n}^{\circ} 1$, ca. 135122) $[S E G 40,118]$. [AC]

239) S.V. TRACY, The Panathenaic Festival and Games: An Epigraphic Inquiry, in Nikephoros, 4 (1991), p. 133-154: Taking a new epigraphic testimony for the Great Panathenaia [infra $\mathrm{n}^{\circ} 240$ ] as a starting point, $T$. collects and discusses the epigraphic evidence about the program and the agons of this festival (IG $\mathrm{II}^{2} 334.959+1014.2311$. 2313-2317). [ES]

240) S.V. TRACY - C. HABICHT, New and Old Panathenaic Victor Lists, in Hesperia, 60 (1991), p. 187-236 [ $B E$ 31. 169]: Ed. pr. of a list containing the victors of the Great Panathenaia in 170,166 and $162 \mathrm{BC}$, with rich historical and prosopographical commentary, especially on the athletic program of the Panathenaia (in which foreigners participated) and the dramatic competitions included in the festival. The new find permits 
a more accurate dating of the Panathenaic victor lists $I G I^{2} 2313-2317$, to which $\mathrm{T}$. and $\mathrm{H}$. offer many restorations. The article includes an up-to-date history of the festival. [AC].

*241) P.R. TREBILCO, Jewish Communities in Asia Minor, Cambridge, 1991 [BE 1993, 410]: This thorough study of the literary, epigraphic, patristic, archaeological, and New Testament sources throws new light on the formation and organization of Jewish communities in Asia Minor (esp. Sardis, Priene, Akmonia, Apamea) in Hell. and Roman times (constitutional position of the Jewish communities, their involvement in city life,

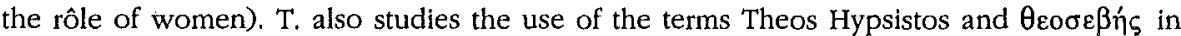
inscriptions. He reaches the persuasive conclusion (p. 127-144) that Judaism in Asia Minor was neither syncretistic nor compromised by paganism, and that the supposed links between Yahweh, Sabazios, Zeus, and other gods called 'Hypsistos' are unfounded. The Jewish influence on the use of the epithet Hypsistos by pagan groups was marginal [cf. supra $\mathrm{n}^{\circ}$ 181]. The term 'Theos Hypsistos' was not easily understood by pagans with the meaning intended by Jews, and its use in Jewish inscriptions gradually declined. The term theosebes was an epithet given not only to Jews, but also to gentiles who were in a regular relationship with the synagogue (Aphrodisias, Pantikapaion, Tralleis, Sardis, Miletos, 1st-4th c. AD). In Asia Minor, more than in other places, the Jewish communities seem to have been open to gentiles learning about Judaism; at least in some cases a form of membership in the synagogue was available to them. $[\mathrm{AC}]$

242) J. TRÉHEUX, L'administration financière des ź $\pi \dot{i} \tau \dot{\alpha}$ ípó à Délos: une théorie nouvelle, in BCH, 115 (1991), p. 349-352 [BE 1992, 335]: $\mathrm{T}$. proposes a new interpretation for the financial administration of the Delian sanctuaries and especially for the administration of the sanctuary of Apollon by the Athenian magistrates ( $\dot{\varepsilon} \pi \dot{i} \tau \dot{\alpha}$ iєpó) after the end of Delian independence $(167 / 6 \mathrm{BC})$. The Delian inventories reveal a procedure by which the Attic and Alexandrian drachmas were separated from coins of other origin (mainly Rhodian), the latter remaining always intact. This procedure may be explained by the fact that the bot epi ta biera excluded all coins whose circulation was not permitted in the Attic monetary system. [ES]

243) J. TRÉHeux, Sur la "Hiéra Syngraphè" de l'indépendance à Délos, in $M H, 48$ (1991), p. 248-251 [BE 1992, 332]: T. argues that the branding of small livestock in Delos (IG XI 2, 287 A 58) aimed at preventing their sale by the lease-holders of the sanctuary. It provided a sort of guaranty, since the livestock remained in the possession of the lease-holders rather than in that of the sanctuary, as was hitherto believed. [ES]

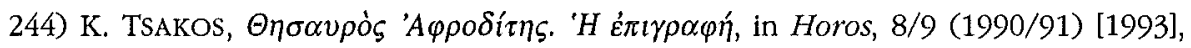
p. 17-28: Ed. pr. of an inscription on a receptacle for donations ( $\theta \eta \sigma \alpha v \rho o ̀ \varsigma ~ \alpha \dot{\alpha} \pi \rho \chi \hat{\eta} \varsigma$ )

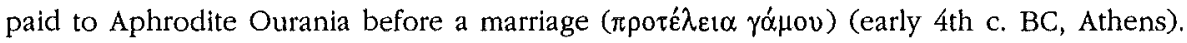
The inscription is probably related to a sanctuary on the north slope of the Akropolis [for such receptacles for the donations of worshippers see now supra $\mathrm{n}^{\circ} 121$ ]. [AC]

245) G. TSETSKhladze, Colchis and Greek Culture: A Problem of Hellenization, in Mesopotamia 26 (1991), p. 119-139: T. presents a synthesis of the data revealed by new excavations on the east coast of the Black Sea, focusing on the Greek colonization of Kolchis and the process of Hellenization. In Kolchis the cults of Apollon, the Dioskouroi, Herakles, Demeter, and Mithras are attested so far. Most of the Greek cults were already established by the late 5th/early 4th $c$. BC. Among the new finds $T$, presents a

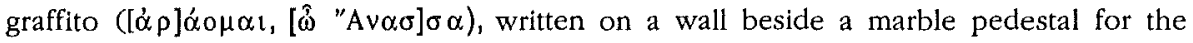


statue of a goddess. This goddess (Leukothea ?) was probably regarded as a protectress of the gates, since her statue was situated near an entrance. [ES]

246) R.A. TYBouT, in $S E G, 38$ (1988) [1991], p. 216-217, $\mathrm{n}^{\circ} 721$ : On the basis of photos and drawings presented to the $S E G$-bureau T. reads the text of an epitaph (Vergina, Hell.) mentioning an hieromnemon. [AC]

247) R.A. TyBOUT, in $S E G, 40$ (1990) [1993]: T. presents an inscribed dolphin statue dedicated to Poseidon (unknown provenance, Hell.), which he saw in the antiquities market (p. $497 \mathrm{n}^{\circ}$ 1606). From a photograph published in Sotbeby's Catalogue, London, Antiquities (31 May 1990), p. $40 \mathrm{n}^{\circ} 305 \mathrm{~T}$. reads the text of a grave inscription (unknown provenance, imp.) with mention of a fine for any violation of the grave; the fine was to be paid to a sanctuary (of Athena?; the reading of this line is not certain). [AC]

248) A. Tziafalias, in $A D, 42$ B1 (1987), p. 285-288 [ $B E$ 1993, 313]: T. presents many new epigraphic finds from Thessaly: Atrax (p. 285-286): A dedication of a woman in fulfillment of a vow $\left(n^{\circ} 10,2 n d c . B C\right)$; notice the name Pannychis $\left(n^{\circ} 21,4\right.$ th $\left.c . B C\right)$. Krannon (p. 287): A dedication to the Charites by a priestess of Artemis $\left(\mathrm{n}^{\circ} 26,1.4\right.$ th $c$. $B C$ ), and a dedication in fulfillment of a vow $\left(n^{\circ} 28,3 r d\right.$ c. BC). Four new grave monuments dedicated to Hermes Chthonios were found in Gonnoi (p. 287, $\mathrm{n}^{\text {os }} 30.32$, 2nd c. BC), Argissa (p. $287 \mathrm{n}^{\circ} 33,2$ nd c. BC), and Larisa (p. $288 \mathrm{n}^{\circ} 45,3 \mathrm{rd} \mathrm{c.} \mathrm{BC).} \mathrm{[AC]}$

249) A. TZIafalias, in $A D, 43 \mathrm{~B} 1$ (1988) [1993], p. 260-284: T. presents many new texts from Thessaly, Larisa (p. 260): A dedication to Poseidon by a woman, as redemption for

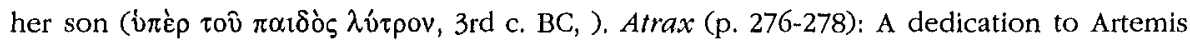
by a priestess ( $v \varepsilon \beta \varepsilon v \sigma \sigma \alpha \sigma \alpha, 2$ nd c. BC) [cf. $E B G R$ 1988, 179] and a dedication to Augustus (Theos Sebastos Kaisar Soter). Pharkadion (p. 279): A dedication (4th c. BC). Pelinnaion (p. 279): A dedication. Chalke (p. 280): A dedication to Agathos Theos (2nd/3rd c.). Krannon (p. 280-281): A dedication to Megas Zeus, a dedication of a thesauros to Asklepios (3rd c. BC) [for these thesauroi cf. supra $n^{\circ}$ 121]. Pbarsalos ( $p, 283$ ): A dedication (3rd c. BC). Agia (p. 284): A dedication in fulfillment of a vow. Four new grave monuments dedicated to Hermes Chthonios (Hell. and imp.) were found in Atrax, Evangelismos, Stavros, and Gonnoi (p. 276-284). [AC]

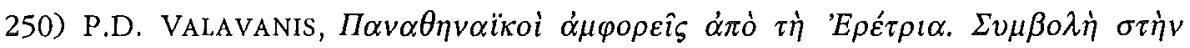

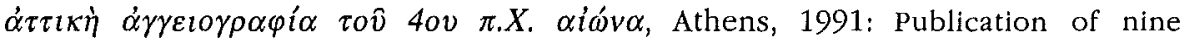
Panathenaic amphoras found in Eretria. According to their inscriptions ( $\tau \hat{\omega} v$ 'A $A$ 'n $v \alpha \theta \varepsilon v$ $\alpha \theta \lambda \omega v)$, they were given as prizes for the Panathenaic agons of the years $363 / 2$ ( 3 pieces) and $360 / 59 \mathrm{BC}$ ( 6 pieces). Although it is not impossible that a native of Eretria won them, it is more likely that they reached Eretria as commercial goods. [AC]

251) D. Vallianou, in $A D, 42$ B2 (1987) [1992], p. 549: Roof tiles inscribed with the name of Asklepios and found in the area of Agiopharango (South Crete, cf. I.Cret, I, xv 3) attest to the existence of an Asklepieion in this area, between the known Asklepieia of Lebena and Lisos. [AC]

252) H. VAN EFFENTERRE, Loi archaique sur l'excès de boisson, in Eleutherna, p. 1721 [ $B E$ 1992, 358]: Ed. pr. of an archaic stele with two prohibitions of drinking (Eleutherna, Crete). The first prohibition of excessive drinking is addressed to citizens (dromeis), perhaps members of a garrison at the border of Eleutherna, as $V$. inferes from the mention of Dios Akron in this context; the exact location of this promontory is still 
unknown. The exact meaning of the second prohibition remains an enigma; it is probably a lex sacra forbidding a priest to drink (or to drink excessively ?) [cf. LSCG 83 1. 41: vńpovtę (oracle at Korope, 2nd c. BC)]. [AC]

253) H. VAN EFFENTERRE, Les deux inscriptions de Nést, in Eleutberna, p. 24-30 [BE 1992, 359. 260]: Ed. pr. of two Hell. inscriptions from Eleutherna (Crete). The first text (E 3) is a treaty of alliance between Eleutherna and Phaistos (3rd c. BC) [and not between Eleutherna and Gortynian exiles, as V. believes; see A. CHANIOTIS, Kretische Inschriften, in Tekmeria, 1 (1995, forthcoming)]. The last lines contain an imprecation for the violation of the treaty. The second inscription ( $\mathrm{E} \mathrm{4}, 3 \mathrm{rd} \mathrm{c} . \mathrm{BC})$ contains the beginning of an oath. According to V.'s restoration, 27 deities were invoked [restored names are marked with an asterisk]: Zeus Kretagenes*, Zeus Tallaios, Zeus Idatas*, Zeus Diktaios*, Zeus Skyllios*, Zeus Thenatas, Zeus Agoraios*, Hera*, Eleithyia*, Athena Skyllia*, Athena Agoraia*, Poseidon, Apollon Lykeios*, Apollon Delphinios, Apollon Pythios*, Apollon Karneios*, Apollon Bilkonios, Apollon Styrakitas*, Apollon Sasthraios, Leto*, Artemis Agrotera*, Ares, Aphrodite, Diktynna*, Britomartis*, Hermes*, and Helios*. Apollon Sasthraios is attested for the first time on Crete; his epithet is certainly related to the ancient name of Eleutherna (Saora or Satra); Zeus Thenatas was worshipped only in Knosos; Apollon Bilkonios was known so far only from an inscription of Magnesia on the Maeander which contains a forged decree of the Creta Koinon concerning the foundation of Magnesia (I.Magnesia 21, 1. 3rd c. BC). V. attempts to connects the new oath with the Cretan Koinon and proposes to locate Bilkon in Eleutherna, where a sanctuary of Apollon has been excavated recently (at the site Nesí). [Several of the restored epithets are unattested on Crete (Athena Skyllia, Athena Agoraia) and many of the restorations are arbitrary. The text is probably the oath of a treaty between Eleutherna and Knosos: see A. CHANIOTIS, Kretische Inschriften, in Tekmeria, 1 (1995, forthcoming)]. Before the beginning of the oath $(1,4), V$, recognizes the word $i \pi \varepsilon \rho \mu \eta p i \delta 1 \alpha$ ('selle d'agneau'), i.e. a

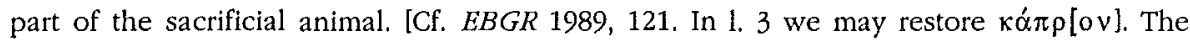
text probably refers to the sacrifice of a trittoia (i.e. of a bull, a boar, and a ram), very common in oath ceremonies: P. STENGEL, Opferbräuche der Griechen, Leipzig-Berlin,

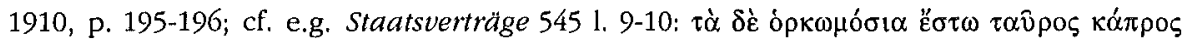

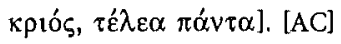

254) E. VARINLIOGLU, Vier Inschriften aus Lydien, in EA, 18 (1991), p. 91-94 [BE 1993, 499]: Ed. pr. of two 'confession inscriptions' (1-2, Museum of Usak, imp.). 1) The

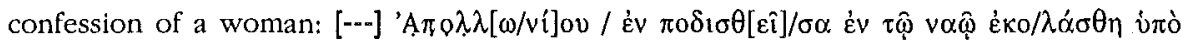

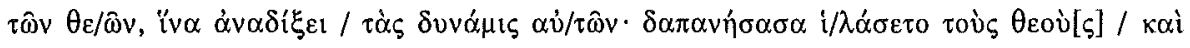

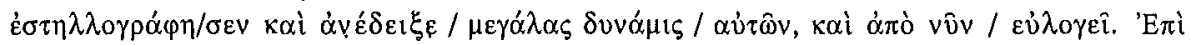

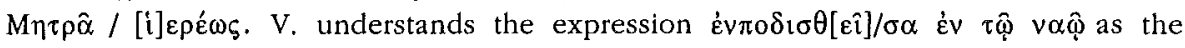
punishment of the sinner; she was kept in detention in the temple ('Gotteshaft') or lost her senses ('besessen, geistig umnachtet') [cf. G. PETZL, in EA, 22 (1994), p. 39: "die Deliquentin wurde im Tempel festgehalten." However, all the parallels show that before

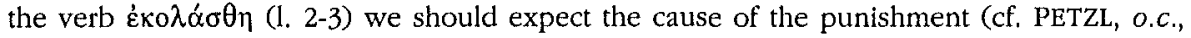
$\mathrm{n}^{\mathrm{os}}$ 6. 7. 9. 22. 23. 34. 35. 43. 47. 49. 50. 54. 57. 60. 62. 63. 64. 65. 71. 76. 96. 99. 101. 106. 114. 117, 120), not the form of punishment. The form of punishment is usually specified

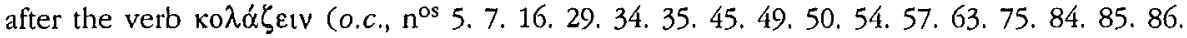
89. 91. 93. 95. 106. 122. PETZL (o.c., p. 39) considers the possibility that év $\pi \circ \delta 1 \sigma \theta[\varepsilon \hat{\imath}] / \sigma \alpha$ E่ $\tau \hat{\varphi} v \alpha \hat{\varphi}$ is the cause of the punishment: "sie mochte 'im Tempel (daran) gehindert 
worden' sein, einer an sie ergangene göttliche Weisung nachzukommen." Another possibility is that the sinner "had been hindered in the temple", i.e. attempted to enter the temple, in violation of a ritual prohibition; cf. e.g. o.c., $\mathrm{n}^{\text {os }}$ 19. 36. 43. 110. 112. 115.

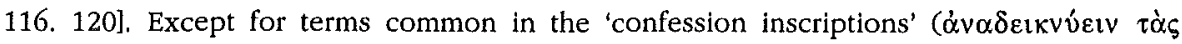

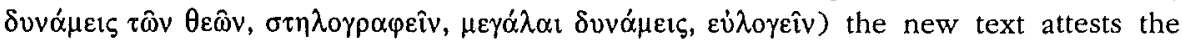
payment of money in connection with the expiation $(\delta \alpha \pi \alpha v \varepsilon \hat{i} v)$. 2) Chryseros and Stratonikos asked the gods ( $\pi \alpha^{\prime} \tau \rho 101 \theta \varepsilon o i$ ) for the means by which they could expiate

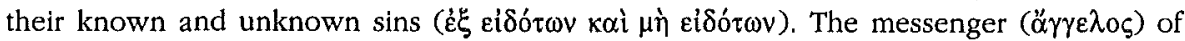
Mes Petraeites Axetenos showed them the proper way, i.e. the payment of 100 denarii. Ammias showed her gratitude for (the cure of ?) Dionysias. Notice the use of the

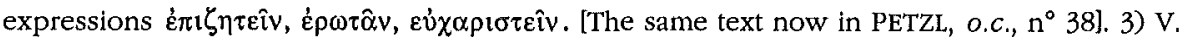

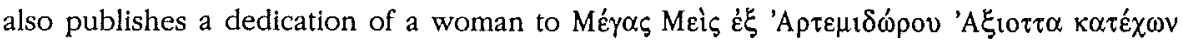
in fulfillment of her vow, after she had inherited her mother [for this meaning of the

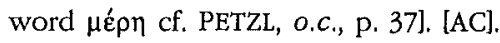

255) V. VASILOPOULOU, in $A D, 42 \mathrm{~B} 2$ (1987) [1992], p. 700: V. reports the exploration of the cave Chrisospilia on Pholegandros, on whose walls hundreds of names were written (4th c. BC ?), including kalos-inscriptions and the names of persons from Siphnos, Seriphos, Crete, and Elis. The cave may have been a site of worship related to the cult of Artemis and Apollon. [AC]

256) C. VATIN, Monuments votifs de Delphes, Roma, 1991 [BE 1992, 78]: V. presents a series of inscriptions he has seen and drawn in Delphi [which, however, have not been seen by anybody else; cf. the critical remarks of M. SĖVE, in $B E 1992,78$ on the reliability of this publication]. Some of the inscriptions have been covered by more recent texts. Only the texts of religious significance are presented here. a) Basis of a statue (imp., p. 39-52): One of the 7 inscriptions records victories of the herald and periodonikes Eklektos (7, 3rd c. AD). b) Dedication of Metapontion (6th/5th c., p. 53-67): $N^{O S} 1$ and 2 record a dedication to Apollon financed with the tithe of the agricultural produce; $\mathrm{n}^{\circ} 3$ records the granting of the privilege of promanteia to Metapontion. c) Stoa of the Tegeans (345 BC, p. 81-101): The texts record the dedication of a tithe of Tegea's booty (sails, weapons) during a war against Sparta. d) Monument of Lysandros (early 4th c. BC, p. 103-138): V. reads the new word $\theta \varepsilon o \theta v \tau$ ńs [sic!], i.e. a sacrificial official. e) Monuments of Argos (p. 139-163): The inscriptions name the Argive heroes. $f$ ) Statues of the eponymous heroes of Athens (p. 165-234): In p. $191 \mathrm{n}^{\circ} 5$ V. reads 'A $\theta$ '́v $\alpha$ [sic!] $\Sigma \omega \sigma[\hat{i}] \pi \mathrm{o}\left[\lambda_{1}\right]$ ]. g) Etruscan dedications (p. 235-259) [cf. EBGR 1987, 123]. [AC]

257) C. VATIN, Das Viergespann des Polyzalos in Delphi: Weibinschrift und Kilnstlersignatur, in Boreas, 14/15 (1991/1992), p. 33-44: After a detailed study of the inscriptions engraved and renewed on the pedestal of the quadriga dedicated by Polyzalos, tyrant of Gela ( 478 or $474 \mathrm{BC}$, Delphi), V. proposes a new reconstruction of

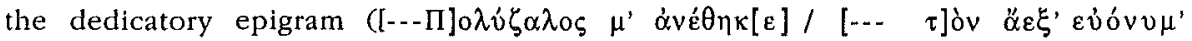
'A 0 ó $\lambda \lambda[o v]$ ) and the signature of the sculptor (Polyzalos of Rhegion). V. believes that the renewal of the dedicatory epigram (twice) was necessary because of the natural erosion of the stone, not because of political reasons. [AC]

258) F. VATTIONI, $A$ proposito $d i$ mrlb', in $E A, 18$ (1991), p. 96 [BE 1993, 611]: $\mathrm{V}$. corrects the reading of supra $\mathrm{n}^{\circ} 148$ to MAPH. $\Lambda \mathrm{AH}$ and discusses the Aramaic term mrll'.[AC] 


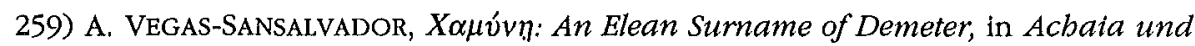
Elis, p. 146-149: V.-S. discusses the cult of Demeter Chamyne in Elis, attested by literary sources (PAUSANIAS), and an inscription ( $I v O$ 485), which mentions a priestess of X $\alpha \mu v v \alpha i \alpha$. V.-S. argues that this archaic epithet of Demeter can be translated as 'having the earth as a bed'. Thus, it reveals features borrowed from the cult of a chthonic deity, e.g. Koví $\alpha$; the cult of Demeter Konia is also attested in Olympia. [ES]

260) C. VELIGIANNI, Weibinscbrift aus Maroneia filr Pbilipp V., in ZPE, 85 (1991), p. 138-144: Ed. pr. of a dedicatory inscription to Zeus and Philip V, called Soter (Maroneia, 187/6-183 BC). The inscription indicates a link between Zeus and king Philip, whose cult was already attested in Maroneia. The worship of Philip is demonstrated by the use of the epitheton Soter, an epitheton usually attributed to Zeus. [ES]

*261) H.S. Versnel, Beyond Cursing: The Appeal to Justice in Judicial Prayers, in Magika Hiera, p. 60-106: Enlarged version of EBGR 1988, 184 (with many additional testimonia, including 'confession inscriptions'). In this important study $V$. recognizes among the defixiones a separate group of 'prayers for justice', which aimed at getting divine support in order to avenge on an evildoer or to restore justice. [AC]

*262) S. VILATTE, La nourrice grecque. Une question d'bistoire sociale et religieuse in $A C, 60$ (1991), p. 5-28: In a general study on feeding in the Greek world, V. discusses the cults of deities which bear the epithet Kourotrophos. The fact that this epithet is shared by more than one deity (Gaia, Athena, Demeter, Eileithyia, Hermes), can be explained by the Greek attitude towards the upbringing of children. This task was undertaken not by the mother, the father, or the educator alone, but by a group of persons. [ES]

263) J. VINogradov, Bulletin épigraphique: Côte septentrionale du Pont, Caucase, Asie Centrale, in REG, 103 (1990), p. 531-560: V. presents an inscribed cup dedicated to Dimeranos, i.e. Zeus (p. $550 \mathrm{n}^{\circ}$ 571, Chersonesos, 3rd c. AD) $[S E G 40,618]$ and a

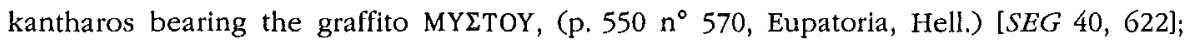
according to $\mathrm{V}$. this is a personal name. Both inscriptions were edited in publications, to which we have no access. [AC]

264) J. Vinogradov, Zur sachlichen und geschichtlicben Deutung der OrphikerPlättchen von Olbia, in Orphisme, p. 77-86: V. shows that the bone plaques from Olbia (Berezan, 5th c. BC, $S E G 28,659-661$ ) [cf. $E B G R$ 1987, 32] with Orphic graffiti were used neither as amulets nor as membership tokens. One plaque contains the words life-deathlife-truth; two others contain pairs of opposite notions, each notion occupying one corner (peace-war, truth-lie, body-soul); by placing one plaque next to another, horizontally, vertically, or diagonally, the owner of the plaques or the priest of an Orphic community could express basic Orphic doctrines (e.g. that the sequence of life, death, and rebirth leads to truth etc.). These texts concern only the moral, not the cosmogonical, aspects of Orphism. V. argues that the Orphics of Olbia were a Dionyssiac association, which together with the Molpoi supported the tyranny of Olbia (5th-early 4th c.). [AC]

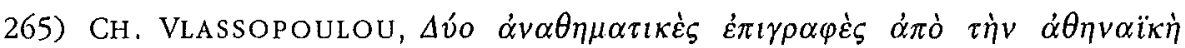

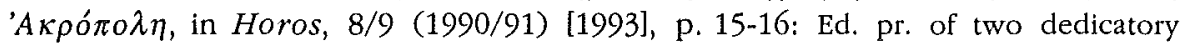


inscriptions from the Athenian Akropolis. The first votive was a work of Euenor (ca, 500 $\mathrm{BC}$ ), the second dedication was a tithe (late 5th c. BC). [AC]

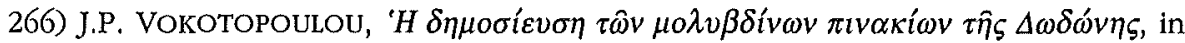
Praktika, 2, p. 81-86: V. reports the progress of the work on the publication of the ca. 2, 500 lead tablets found in the oracle at Dodona and containing questions addressed to Zeus. [AC]

267) J.P. VOKOTOPOULOU, in $A D, 42$ B2 (1987) [1992], p. 367-368: A new rural shrine, dedicated to the cult of a chthonic goddes, was found in a site identified with Sane (Chalkidike, arch.). Two sherds of vases bear dedicatory inscriptions. On one of them the epithet of the goddess is partly preserved: $\tau \hat{\alpha} \zeta \Pi v \theta[i \alpha \varsigma]$ (i,e. Artemis Pythia) or $\tau \hat{\alpha} \varsigma$ $\Pi v \theta[o v i ́ k \alpha$ ] (Aphrodite Pythonika). [AC]

268) R. WACHTER, The Inscriptions on the Françoise Vase, in MH, 48 (1991), p. 86113 [BE 1992, 41]: Reedition of the 129 inscriptions on the Françoise Vase (ca. 570 BC), mostly labels of the mythological scenes depicted on it. W. offers many new readings and restorations as well as a linguistic and mythological commentary on the inscriptions. W. strengthens the view that Klitias was a highly literate painter who drew from poetic sources, as demonstrated by a comparison of the order of names of the Centaurs and the Muses on the Françoise Vase and in literary sources. [AC]

269) G. WAGNER, Épigraphie grecque d'Égypte : À propos d'une nouvelle inscription d'Akôris, in Mélanges Bernand, p. 387-392: Discussion of a dedication to Hera and Aphrodite for Tiberius by a Roman woman (Akoris, AD 29) [EBGR 1989, 73; in the ed. pr. the text had been misunderstood as a dedication to Hera Aphroditel. While the cult of Hera (Mout) was known in Akoris, this is the first attestation for the cult of Aphrodite (Hathor). Dedications by women alone are rare in Egypt; two further examples, both dedications to Aphrodite, are known from Philai (I.Philai 311) and Kom Ombo (A. BERNAND, De Thèbes à Syène, Paris, 1989, $\mathrm{n}^{\circ}$ 193). [AC]

270) M.B. WaLBanK, Leases of Public Land, in Agora, XIX, p. 147-207 [BE 1992, 8; cf. $S E G$ 40, 125]: Corpus of the leases of public land found in the Athenian Agora, with a very good introduction to the subject. Several texts concern the leasing of sacred property: L2 (temene in Euboia), 6, 9-12, 13 (a theater in Piraeus), 14, 16 (orgeones of Bendis). The corpus includes several leges sacrae: a) The settlement of a dispute between the Salaminians of Heptaphylai and Sounion (L4 $=$ LSS 19), with regulations about sacrifices and priesthoods (of Athena Skiras, Herakles in Porthmos, Eurysakes, Aglauros, Pandrosos, and Kourotrophos); b) a decree about the funding for the lesser Panathenaia ( $\mathrm{L} 7=\operatorname{LSCG} 33$, ca. 338-330 BC) [cf. supra $\mathrm{n}^{\circ} 209$ ]; c) a fragmentary lex sacra of the deme of Melite (LA1, ca. 480-475).

*271) H. WaldmanN, Der kommageniscbe Mazdaismus, Tübingen, 1991: Study of the religious developments in Kommagene after the reforms of king Antiochos I with extensive use of epigraphic testimonia (presented in p. 197-208), including a reedition of 1. 34-36 of the 'lex sacra' from Arsameia (p. 171-177), an inscribed altar dedicated to

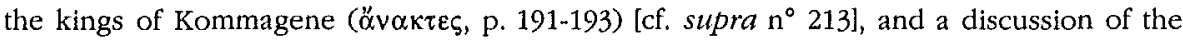
inscriptions from the mausoleum at Hasanoglu, the temenos at Doliche, the hierothesion of Karakus, and the shrine at Sofraz Köy. [AC] 
*272) L. WATSON, Arae. The Curse Poetry of Antiquity, Leeds, 1991: This study focuses on the curse poetry from Homer to the 1st c. $A D$, with special emphasis on the Hellenistic examples (Kallimachos, Euphorion, Moiro, Theokritos, P.Sorbonn. 2254). W. discusses the relation between prayer and cursing [cf, supra $n^{\circ} 90$ ], the execution of curses, the various sub-categories of curses, their themes, phraseology, and aims; he makes extensive use of epigraphic sources. The most interesting conclusion is the emphasis curses give to the principle of justice [cf. EBGR 1988, 184 and supra $\mathrm{n}^{\circ} 261$ ]. In an appendix (p. 194-216) W. argues that the influence of defixiones on the Hellenistic curse poetry was only marginal. The book includes a very useful index of curse themes (p. 254), [AC]

273) P. WEISS, Auxe Perge. Beobachtungen zu einem bemerkenswerten städtischen Dokument des späten 3. Jabrbunderts n. Cbr, in Cbiron, 21 (1991), p. 353-392 [BE 1992, 523]: Discussion of the acclamations of Perge (ca. 275/6 AD, SEG 34, 1306) [EBGR $1988,117 ; 1990,264]$. W. corrects the reading of 1.11 : It is not an invocation of Diana Ephesia and Diana Peresia (sc. Pergesia), but a reference to the Ephesian agon: $\delta, \dot{\alpha} v \varsigma^{\prime}$

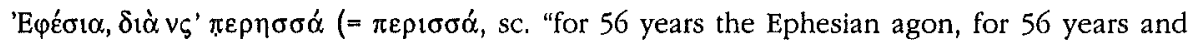
more"). The period of 56 years begins with the granting of the fourth neokoria to Ephesos by Elagabalus. According to W.'s restoration, the background of these acclamations was the inauguration of a new agon in Perge, founded by the emperor Tacitus (Agon Metropolitios); the mention of the Ephesian agon was a compliment to the Ephesian delegation present at this event. The good relations between Ephesos and Perge date back to the reign of Valerian, when the agon Asylia Pythia was inaugurated (cf. the numismatic evidence). W. collects in p. 362 ss. examples for the presence of foreign delegations at the inauguration of festivals and agons ( $\sigma v v \theta v \sigma i \alpha, \sigma v v \varepsilon o \rho \tau \alpha \dot{\zeta} \zeta \varepsilon v$ ).

274) D. WhITEHEAD, The Lampadephoroi of Aiantis Again, in ZPE, 87 (1991), p. 4244: Restorations to the decree $E B G R$ 1990, 277 concerning a torch-race in classical Athens. [AC]

275) D. WILLERS, Zwei Thesmophorien in Eretria?, in MH, 48 (1991), p. 176-187: On the basis of the published inscriptions from Eretria, W. discusses the local cults, underlining how difficult it is to combine archaeological, epigraphic, and literary data. As an example he discusses the 'Old Thesmophorion', which in his opinion may represent the sanctuary of a deity other than Demeter. [ES]

276) C. Williams - H. Williams, Excavations at Mytilene, 1989, in EMC, 34 (1990), p. 181-193: Two folded lead tablets were found in a sanctuary (possibly of Demeter, Hell.). Unlike the curse tablets found in 1987 [EBGR 1988, 191] they do not have bronze spikes through them, and may be votive or thank offerings, rather than curses, [AC]

277) C. Williams - H. Williams, Excavations at Mytilene, 1990, in EMC, 35 (1991), p. 175-191: The attribution of the excavated sanctuary in Mytilene to Demeter has been confirmed; her name has been read on one of the lead tablets found in 1989 (p. 176) [see supra $\mathrm{n}^{\circ} 276$ ]. This is the first known Thesmophorion on Lesbos. Perhaps Demeter was worshipped together with Kybele [cf. $E B G R$ 1988, 191]. The finds also include an inscribed loom-weight, probably a dedication (p. 189). [AC]

278) M. WÖRRLE, Epigraphische Forscbungen zur Geschichte Lykiens IV. Drei griechische Inscbriften aus Limyra, in Chiron, 21 (1991), p. 203-239 [BE 1992, 478]: 1) 


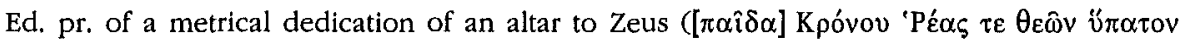
$\left.\Delta i^{\prime} \alpha\right)$ by the Lykian dynast Perikles (Limyra, early 4th c. BC); in his detalled historical commentary W. underlines the significance of the Homeric tradition (especially the story of Sarpedon) for the Lykian dynasts and discusses the important Zeus cult in Limyra. 2) Ed. pr. of an honorific inscription of the Pernitai (Limyra, late 4th c. BC), with a penal clause for any destruction of the inscription: The guilty person should be liable to

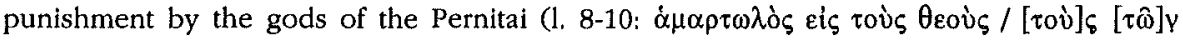

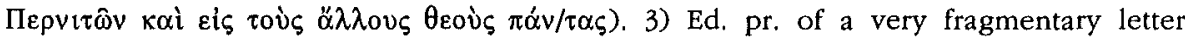
(Limyra, $4 \mathrm{th} / 3$ rd c. BC). The document at least partly concerns religious matters, as can be inferred from the mention of an hierokeryx and a priest. [AC]

279) F. ZAYAdine - S. FARajat, The Petra National Trust Site Projects, Excavation and Clearance at Petra and Beida, in ADAJ, 35 (1991), p. 275-295 [BE 1993, 648]: Z.-F. present two Greek inscriptions from the temple of Quasr el-Bint (Petra), a dedication to Zeus Hypsistos, assimilated to the Syrian Baalshamin and the Nabatean Dusares (no date), and a dedication to Aphrodite for an unknown emperor ( $3 \mathrm{rd} \mathrm{c}$. AD); the sanctuary of Aphrodite, assimilated to the Nabatean goddess al-Uzza, prospered in the 2nd c. $\mathrm{AD} .[\mathrm{AC}]$

280) G. Zinserling, Attische Grabluxusgesetze und Römische Pompa Funebris, in Helikon, 31/32 (1991/1992), p. 407-414: Collection and interpretation of the literary sources on Solon's funerary and sumptuary laws. [Epigraphic testimonia, e.g. the lex sacra from Iulis (LSCG 97), have not been used; on this subject cf. EBGR 1990, 101]. [ES]

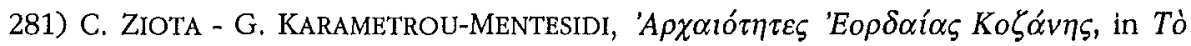

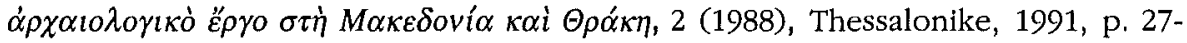
33: Mention of a dedication to Apollon Hekatombios (Kastro Eordaias, 1st c. BC) [cf. $E B G R$ 1990, 156]. [AC]

\section{Angelos CHANIOTIS}

Department of Classics

New York University

25 Waverly Place NEW YORK, N.Y. 10003

\section{Eftychia STAVRIANOPOULOU}

Seminar für Alte Geschichte

Universität Heidelberg

Marstallhof 4

D - 69117 HEIDELBERG 